Representaciones sociales en algunos operadores jurídicos e indígenas acerca del acceso a la justicia de grupos étnicos afectados por el desplazamiento forzado

Trabajo de Grado

\author{
Castaño-Saldarriaga Mario \\ Óscar Fernando Acevedo Arango*
}

Universidad Santo Tomás

Facultad de Psicología

Bogotá, D.C., Julio 18 de 2014

${ }^{*}$ Director. 


\title{
Representaciones sociales en algunos operadores jurídicos e indígenas acerca del acceso a la justicia de grupos étnicos afectados por el desplazamiento forzado
}

\author{
Castaño -Saldarriaga Mario, Acevedo Arango Óscar Fernando*
}

Resumen

Las representaciones sociales de algunos operadores jurídicos que laboraron en entidades gubernamentales y no gubernamentales de Bogotá, develan creencias que pueden intervenirse para brindar un acceso eficaz a la justicia estatal de indígenas en situación de desplazamiento forzado. Esta investigación se propuso como objetivo analizar representaciones sociales de indígenas y algunos operadores jurídicos que laboraron en entidades públicas y privadas de Bogotá, sobre los grupos étnicos en situación de desplazamiento forzado y su acceso a la justicia. El presente estudio se enmarcó dentro de una investigación de enfoque cualitativo. Para la obtención de los resultados se entrevistaron doce participantes; cuatro indígenas hombres, adultos, pertenecientes a la etnia Wounaan, y ocho operadores jurídicos residentes en Bogotá. Los datos fueron recolectados mediante la técnica de entrevista semiestructurada, la cual arrojó como resultado que algunos operadores jurídicos poseen opiniones negativas de los indígenas afectados por el desplazamiento forzado, estos carecen de capacitación adecuada en cuanto a la aplicación del enfoque diferencial, y se observa la inexistencia de protocolos específicos para la atención de las diversas etnias indígenas.

Palabras clave: Representaciones sociales (32113); Derecho de acceso a la justicia (24330); Enfoque diferencial (23320); Atención a indígenas (20332); Vulneración de los Derechos Humanos (24250); Victimización (23331)

\section{Social in some legal and indigenous operator's representations about access to justice for ethnic groups affected by forced displacement}

Social representations of some legal practitioners, who worked in governmental and non- governmental institutions and the country Bogotá, reveal beliefs and obstacles that can be intercepted to provide effective access to justice for indigenous state in forced displacement. This research aimed to analyze social representations of some legal practitioners who worked in public and private entities in Bogota and in the country and Indians forced displacement. This study formed part of an investigation of qualitative descriptive approach and the accompanying discourse analysis of significant narratives. To obtain the results four indigenous men, adults, belonging to ethnic Wounaan, legal operators eight adult men and women living in Bogotá were interviewed. Data were collected by the technique of semi-structured interview, throwing resulted in some legal operators have negative evaluations of indigenous and the displacement of indigenous , lack of adequate training in differential approach and lack of specific protocols for dealing with indigenous groups .

Keywords: Social representation (32113); Right of access to justice (24330); Focus (23320); Attention Indians (20332); Human Rights (24250); Victimization (23331).

\footnotetext{
* Director.
} 


\section{Tabla de contenido}

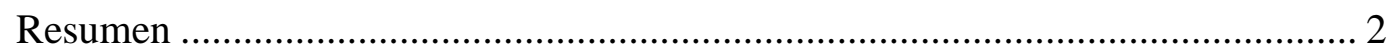

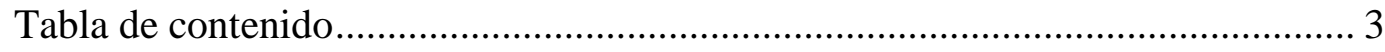

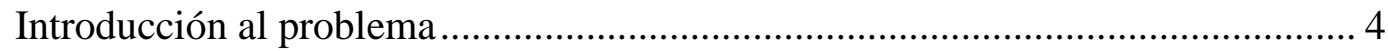

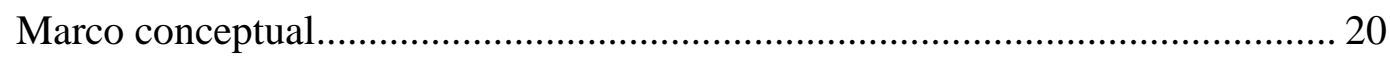

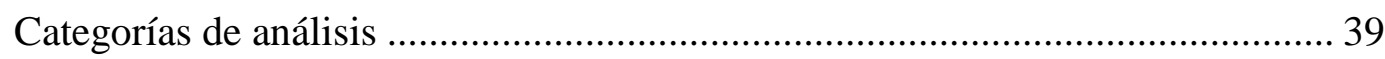

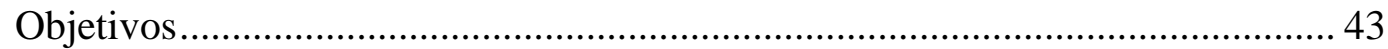

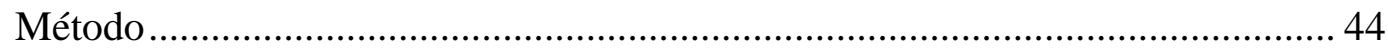

Resultados y discusión entre el marco conceptual y los hallazgos......................... 49

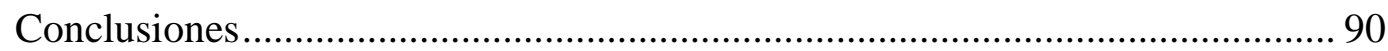

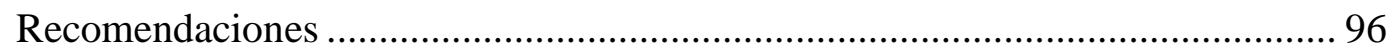

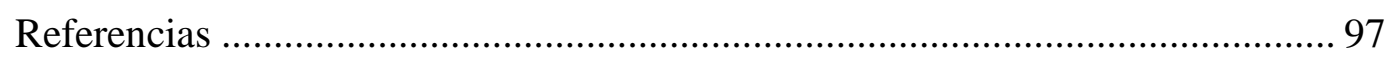

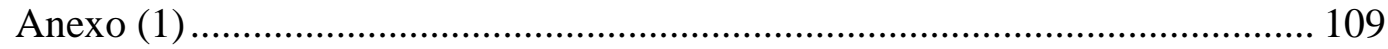

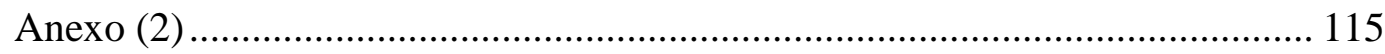

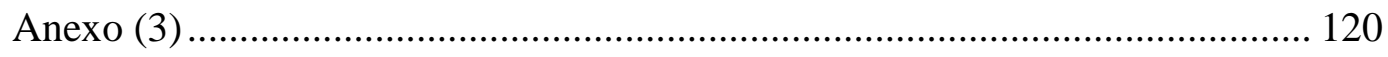




\section{Introducción al problema}

El acceso a la administración de justicia es un derecho fundamental que se encuentra consagrado en los artículos 228 y 229 de la Constitución Política Colombiana, este derecho parece demasiado abstracto ya que para muchas personas pertenecientes a comunidades vulnerables como los indígenas en situación de desplazamiento forzado les ha sido imposible obtener el verdadero acceso a la justicia, el cual tiene por finalidad restablecer sus derechos materiales de salud, vivienda, empleo, educación, alimentación, de acuerdo a lo establecido en la Sentencia C- 1027/02 y el enfoque diferencial en derechos humanos contenido en la ley 1448 de 2011.

Alrededor de 70,000 desplazados internos registrados en Colombia son miembros de grupos indígenas. El desplazamiento forzado entre estas comunidades se ha incrementado en los últimos cinco años y creció más que el del resto de la población entre 2006 y 2008. Acorde con las cifras estatales, entre el 2004 y el 2008 se desplazaron 48.318 personas pertenecientes a pueblos indígenas (aproximadamente el $70 \%$ del total de desplazamiento forzado indígena registrado). La Organización Nacional de Indígenas de Colombia, ONIC, considera que las cifras pueden ser mayores teniendo en cuenta que muchos indígenas no tienen acceso al registro, debido a la lejanía de sus tierras o porque no hablan español o desconocen el sistema nacional de registro. En los últimos diez años, los indígenas han padecido un notorio acrecentamiento de la violencia relacionada con el conflicto armado. En el periodo entre 1998 y 2008, la ONIC reportó el asesinato de 1,980 indígenas (ACNUR, 2009, p. 33). 
La comunidad Indígena Wounaan, proveniente del Bajo San Juan-Departamento del Chocó- es uno de los 35 grupos declarados en peligro de extinción por la Corte Constitucional en su Auto 004 de 2009 y para las cuales ordenó medidas de protección especiales (Oficina internacional de los derechos humanos acción Colombia, 2013).

Los resultados son claramente observables, dado que indígenas pertenecientes a la etnia Wounaan, víctimas de desplazamiento forzado, residen actualmente en la localidad de Ciudad Bolívar en condiciones precarias sin acceso a los recursos básicos para la satisfacción de sus necesidades vitales. El presente trabajo pretende analizar las representaciones sociales de algunos integrantes de grupos indígenas de la etnia Wounaan, afectados por el desplazamiento forzado y de operadores jurídicos que laboraron en entidades de carácter gubernamental (Centro Dignificar, Localidad de Suba) y no gubernamental (diversas ONG), los cuales mediante la atención procuraron garantizar el derecho de acceso a la justicia a miembros de etnias indígenas aquejadas por este fenómeno.

A nivel teórico la concepción de las representaciones sociales descrita por Serge Moscovici (1961) tiene varios seguidores dentro de la psicología social, la cual a pesar de las críticas ha demostrado ser un enfoque independiente que proviene de la corriente sociológica europea aplicada a la cotidianidad, al sentido común, a la pragmática y a la realidad (Banchs, 2001, p. 56).A través de varios procesos se convierte lo desconocido en algo popular usando mecanismos de anclaje y objetivación, Moscovici (1981, p. 47). Este enfoque social de la representación se ubica en contraposición a la teoría de las cogniciones sociales de origen norteamericano que estudia principalmente el procesamiento de la información teniendo en cuenta las atribuciones y percepciones 
(Páez y Carbonero, 1993, p. 16). Cabe señalar, que en este último enfoque el ser humano piensa de manera lógica e individual centrándose principalmente en los mecanismos empleados para realizar los procesos cognitivos no tanto en la profundización simbólica ni relacional de los contenidos (Rodríguez, 2003, p. 85).

Entre los debates sobre las representaciones sociales, RS, aparecen las críticas que hacen varios teóricos referentes a que el conocimiento común es elaborado en espacios distintos al conocimiento científico, a lo que Moscovici (1979, p.19) señala que: "en la actualidad el conocimiento común y el científico se encuentra amalgamado en la sociedad, ya que a través de los medios de comunicación y revistas especializadas muchas personas acceden a toda clase de conocimientos".

Cierto es, que son numerosos los debates que se encuentran vigentes sin llegar a consenso alguno, como los efectuados entre la psicología discursiva y las representaciones sociales, la ambigüedad en la definición de las representaciones sociales, entre otros. De los cuales no se profundizará en el presente trabajo.

Las representaciones sociales, RS, son una modalidad particular del conocimiento, cuya función es la elaboración de los comportamientos y la comunicación entre los individuos. Estas son un corpus organizado de conocimientos y una de las actividades psíquicas gracias a las cuales los hombres hacen inteligible la realidad física y social, se integran en un grupo o en una relación cotidiana de intercambios... (Moscovici, 1979, p. 17-18; citado en Mora, 2002, p. 7).

Las representaciones sociales como sistemas sociales de valores, ideas y prácticas, cumplen dos funciones: orden y comunicación. En la concepción de Moscovici, se plantean cuatro elementos constitutivos de las representaciones 
sociales: La información, que se relaciona con lo que "yo sé"; la imagen que se relaciona con lo que "veo"; las opiniones, con lo que "creo"; las actitudes, con lo que "siento", estos elementos los tomamos como guía para el análisis de la información (Zamora, 2007, p. 25).

Pese a lo anterior, para ir más allá del lugar común de la representación social como referente de la psicología social y de la sociología, se propone la concepción que sobre la representación de los estudios culturales desarrolló Hall Stuart (1997) en su texto "El trabajo de la representación", quien introduce el valor del poder interior y de la política contextual de la representación tomando como referente el análisis discursivo de Michel Foucault (Hall, 1997, p. 2). De tal manera, procuramos en este trabajo acercar el estudio de las representaciones sociales a la psicología jurídica, especialmente sobre la manera como los operadores jurídicos hacen uso de sus prejuicios culturales como prácticas de poder y de exclusión sobre los indígenas desplazados y sus derechos. Dando pie a la consideración sobre la manera como la psicología jurídica debe ocuparse de las relaciones de poder inscritas en el vínculo entre el psiquismo y la ley, entre las personas y las normas, entre el ciudadano y el Estado.

Respecto del desplazamiento forzado por la violencia, nos inscribimos en la concepción de éste como un delito sociopolítico que ha venido ocurriendo desde hace varias décadas en diferentes partes del mundo. La OMS (2002) en el informe mundial sobre violencia y la salud, afirma que en países de África, Asia, Europa, son millones de personas desplazadas a través de la violencia a raíz de los conflictos armados y de las macro-victimizaciones generadas por las políticas del desarrollo económico excluyente que se han visto obligadas a huir de sus territorios para salvar sus vidas debido a la presencia de conflictos de origen político, económico, religioso y étnico (pág. 78). 
Lo mismo ha sucedido en Colombia que es un Estado que pervive en continuo conflicto armado interno desde el momento de su creación.

Para tratar de entender el fenómeno del desplazamiento forzado interno, se debe hacer un recorrido histórico mencionando algunos hechos violentos acaecidos que representan el comienzo del conflicto nacional. En efecto, el desplazamiento forzado contra los indígenas se constituye en un delito sociopolítico de vieja data, se puede afirmar que desde la nombrada época de la conquista (1492), los nativos del continente americano fueron, aniquilados, desterrados, exiliados y desplazados, y miles de ellos asesinados a manos de los invasores, conquistadores y colonizadores. "A la llegada de los españoles formaban todavía una cultura viva y densa, que no soportó el contacto con los invasores europeos" (Melo, 1996, p. 82).

Instituida la colonización y el desplazamiento como prácticas de dominación al margen de la democracia siglos más tarde, pervive en la memoria colectiva colombiana esta modalidad de apropiación de la tierra, de la riqueza y del ser del otro como modo de expropiación de su hábitat, de sus hábitos y de su capital intelectual y cultural. En Colombia surge la llamada época de la violencia política, denominada violencia con "V" mayúscula por parte de los sociólogos e historiadores donde se disputaron el poder los partidos oficiales conformados por conservadores y liberales. “...la violencia, durante las décadas de los cuarenta y cincuenta, es justificada precisamente por la incapacidad de abordar la diferencia, en la esfera pública, y por el deseo de implantar el dominio de un partido sobre el otro"... (Lora, 2011, p. 139).

Un capítulo importante de la historia violenta colombiana tiene su inicio con el asesinato el 9 de abril de 1948 del político Jorge Eliecer Gaitán Ayala, lo cual incrementó la muerte, destrucción de viviendas y desplazamiento interno de los 
pobladores de las zonas rurales hacia las ciudades. "Su muerte conduce al país a uno de los mayores levantamientos populares que, por su magnitud, se ha conocido como el Bogotazo; rebelión que permite a las masas populares tomarse el espacio público...." (Lora, 2011, p. 47).

Posteriormente, a fines de 1960, los conservadores y liberales después de realizar varias rondas de conversaciones lograron ponerse de acuerdo a fin de compartir el poder creando "el Frente Nacional", que gobernó durante 16 años consecutivos comprendidos entre 1958 a 1974, excluyendo con este pacto las demás opciones políticas, especialmente las de izquierda que al no encontrar un lugar dentro de la nombrada democracia colombiana produjeron el estado del conflicto armado, originando el desplazamiento forzado en Colombia al dejar en medio de dicha disputa a la población civil. “...los sectores políticos independientes se unen, dando paso a la formación de grupos armados, y a la acentuación de la descomposición del campesinado, que es desalojado hacia las zonas urbanas" (Lora, 2011, p. 184).

En este lapso de tiempo surgieron decenas de grupos subversivos, entre los que se destacan el M-19 y el ejército popular de liberación, EPL. Con los que se produjeron sendos procesos de amnistía y paz, pero también los dos principales grupos subversivos denominados fuerzas armadas revolucionarias de Colombia, FARC y el ejército de liberación nacional, ELN ( Lair, 200, p. 137).

Por otra parte, con el fin de combatir la presencia guerrillera en el país, surgen en la década de 1980 los grupos paramilitares que realizaron un proceso de desmovilización durante el mandato del gobierno de Álvaro Uribe Vélez, desmovilización de la que se cuestiona su eficacia ya que muchos continúan operando de manera ilegal bajo el nombre de bandas criminales, BACRIM, empleando diversas 
auto-denominaciones tales como los rastrojos, los urabeños, las águilas negras, los paisas y otros (Lora, 2011, p. 272).

De hecho, en la actualidad estos grupos junto con las organizaciones guerrilleras que tienen su accionar en casi la totalidad del territorio nacional, son responsables de la ejecución de algunas masacres y desplazamientos forzados de las diversas comunidades indígenas. Estos desplazamientos se presentan generalmente por intereses económicos debido a que los grupos armados pretenden apoderarse de tierras simplemente por la posesión, por ser ricas en madera, oro, petróleo y otros minerales, en la plantación de cultivos ilícitos de coca, marihuana y amapola, la creación de rutas de narcotráfico. "Los grupos armados han desarrollado una economía de guerra articulada en recursos que ligan lo local a lo internacional" (Lair, 2000, P. 140). También para ser usadas por multinacionales en la construcción de mega proyectos, desconociendo el convenio No. 169 de 1991, Organización internacional del trabajo, OIT, donde el gobierno debe consultar a los diferentes grupos indígenas acerca de las medidas legislativas o administrativas que afecten su cultura y calidad de vida dentro de sus territorios.

Se carece de registros exactos sobre el número de indígenas desplazados por la violencia que ingresan diariamente a la ciudad de Bogotá, toda vez que se trata de población nómada, móvil o llamada técnicamente "flotante". Entidades gubernamentales encargadas del Sistema Nacional de Atención y Reparación Integral a las Víctimas, la Unidad para la Atención y Reparación Integral a las Víctimas, Agencia Presidencial para la Acción Social y la Cooperación Internacional, que en la actualidad se convirtió en el Departamento Administrativo denominado Departamento para la Prosperidad Social, DPS, la Alta Consejería para la Atención y Reparación de las Víctimas, la Paz y la Reconciliación de la Alcaldía Mayor de Bogotá, “Centros Dignificar” (Unidades de 
Atención Integral a Población Desplazada), manejan las estadísticas de la población afectada por dicho fenómeno bajo parámetros diferentes.

En un encuentro realizado en el año 2014, entre el presidente de Colombia y los indígenas del Cauca, Luis Fernando Arias, representante de la Organización Nacional de Indígenas, ONIC, le manifestó al Jefe de Estado que: "En sus dos años de gobierno ha tenido que lamentar la desaparición de 257 indígenas y el desplazamiento de unos 10.000 más" (El Tiempo, 25 de abril de 2014).

De acuerdo con la información contenida en el Registro Único de Población Víctima, RUPV, del Sistema Nacional de Atención y Reparación Integral a las Víctimas del conflicto armado interno, con corte a Septiembre 30 de 2012, el número de personas que se encontraban en situación de desplazamiento forzado en Colombia ascendía a 4.662.587, equivalente a 1.063.482 hogares. De este total Bogotá ha recibido 366.087 personas, correspondientes a 89.960 hogares, lo cual implica que en promedio por mes llegaron a la ciudad 207 familias. Sin embargo, aunque la ciudad es la principal receptora de personas en condición de víctimas, también expulsó a 6.909 de ellas, que correspondían a 1.495 hogares (Proyecto de Presupuesto 2013, Bogotá, Distrito Capital Anexo 4).

Los indígenas en Colombia representan el 2,74\% del total de la población colombiana y el 3,4 \% de los casi 3.900.000 desplazados internos. Desde 1997 hasta 2011, se desplazaron un total de 106.562 y sólo en el 2011 se desplazaron a 4.080 indígenas. Conforme con cifras oficiales, aproximadamente el $2 \%$ del total de personas desplazadas del país pertenece a alguna etnia indígena (ACNUR, 2012, p. 14). 
La información suministrada por la Unidad para la Atención y la Reparación Integral a las Víctimas, en Bogotá reportó a 7 de febrero de 2013, un total de 400.340 víctimas correspondientes a 91.208 hogares. Del total de personas 90,4\% son víctimas de desplazamiento forzado. Según datos aportados por la UARIV, 9.413 se reconocen como indígenas. La ONIC, afirma que son 25 pueblos indígenas que hacen presencia en Bogotá (Alcaldía Mayor de Bogotá, Plan de acción Distrital de prevención, protección y reparación integral a las víctimas 2013-2016).

Cabe señalar, que las víctimas del conflicto armado interno se encuentran amparadas jurídicamente por la Constitución Nacional, Ley 387 de 1997, Sentencia T025 de 2004, Ley 1448 de 2011, Decreto Ley 4633 de 2011, Ley 975 de 2005, Ley 599 de 2000, Decreto 4800 de 2011 etc., que de manera general tratan sobre la garantía de los Derechos Humanos y las jurisdicciones especiales que poseen los indígenas.

Al momento de hacer su aparición en la ciudad capitalina, los indígenas víctimas de desplazamiento forzado procedentes de diversos departamentos del país, acuden a instituciones como la Procuraduría General de la nación, Defensoría del Pueblo, Personería Distrital, Unidades de Atención Integral a Población Desplazada, entre otras. Donde son orientados algunas veces por funcionarios de la Unidad para la atención y reparación integral de víctimas, UARIV, Alta Consejería para la Atención y la Reparación de Víctimas, Secretaría Distrital de Gobierno, Secretaría de Hábitat, Familias en Acción y la Secretaría de Integración Social, hacia distintos albergues provistos en varias localidades para la atención de los grupos étnicos desplazados por la violencia, debiendo ser inicialmente reconocidos como víctimas de este flagelo 
mediante la valoración de la declaración de los hechos rendida ante el ministerio público, para ulteriormente ser inscritos en el Registro Único de Población Desplazada, RUPD y el Sistema de Información de población Desplazada, SIPOD, con el fin de obtener la asistencia a través del suministro de subsidios en educación, salud, registraduría, seguridad y comedores comunitarios.

De acuerdo con la Ley 1448 de junio 10 de 2011, por la cual se dictan medidas de atención, asistencia y reparación integral a las víctimas del conflicto armado interno, y el Decreto 4800 de 2011 que la reglamenta, se ordena hacer efectivo el pleno goce de los derechos a la verdad, justicia y reparación. El artículo segundo establece que: "Las medidas de atención, asistencia y reparación de los pueblos indígenas [...] harán parte de normas específicas para [...] estos grupos étnicos, las cuales serán consultadas previamente a fin de respetar sus usos y costumbres, así como sus derechos colectivos, [...] ". El Decreto 4800 de 2011, artículos 226 y 218, hace referencia a los informes de los programas de protección dirigidos a los indígenas desplazados que deben rendir semestralmente las instituciones encargadas ante las respectivas autoridades de las entidades territoriales con el fin de evaluar los resultados, medidas y mecanismos para ofrecer protección colectiva a los grupos indígenas. De igual manera, el Decreto Ley 4633 de 2011, especifica las medidas de atención, asistencia y reparación integral a las comunidades indígenas como sujetos colectivos e individualmente a los integrantes de estos grupos que hayan sido víctimas de vulneraciones de los Derechos Humanos.

A pesar de lo contemplado en las normas señaladas referentes al trato diferencial con las que deben ser atendidas dichas comunidades, los indígenas en situación de desplazamiento forzado son ubicados en varias localidades de la capital donde tienen que acomodarse a los usos, costumbres, aparato de justicia y en general al modo de vida 
de los ciudadanos comunes residentes en Bogotá, lo que pone en riesgo de desaparición su capital cultural, sus prácticas y costumbres, mientras que a la par no son atendidos, asistidos ni reparados de acuerdo a su singular cosmovisión, ocasionando el incumplimiento de las leyes colombianas y de los tratados internacionales, la transgresión de sus derechos fundamentales y la victimización secundaria.

Además, para optimizar la atención es necesario replantear los criterios que emplea la Unidad de atención y reparación integral a las Víctimas, UARIV, en cuanto a la inclusión o no de los grupos indígenas víctimas al Registro Único de Población Desplazada.

De igual manera, la Ley 975 de 2005, artículo $6^{\circ}$ manifiesta acerca del derecho a la justicia que [...] "El Estado tiene el deber de realizar una investigación efectiva que conduzca a la identificación, captura y sanción de las personas responsables por delitos cometidos por los miembros de grupos armados al margen de la ley [...] que reparen el daño infligido, $[\ldots]$ ”. Dejando entrever que la justicia colombiana en ocasiones se dedica a restituir algunos derechos sin hacer suficiente énfasis en el daño psicológico y la dignidad de los pueblos indígenas que son revictimizados por el mismo aparato jurídico del Estado, toda vez que, a veces por acción u omisión de algunos deberes que conciernen a los operadores, las víctimas de desplazamiento forzado terminan agravando su difícil situación, trayéndoles consecuencias negativas para sus proyectos de vida, a nivel físico, económico y psicológico.

En este orden de ideas, si la psicología jurídica se entiende como el "Campo especializado de la ciencia psicológica básica y aplicada, relacionada con los conflictos humanos que alcanzan implicación jurídica y que propende por el respeto a los Derechos Humanos y la Salud Mental.” (Tapias, Hernández, Gutiérrez, Sicard, 2009; citado en 
Gutiérrez, 2010, p. 5). Entonces cabe mencionar, que el presente trabajo articula con la psicología jurídica debido a que señala las relaciones entre las representaciones de la ley y los derechos que tienen los operadores jurídicos sobre las etnias afectadas, como los que poseen los indígenas víctimas de desplazamiento forzado.

En este estudio se tuvieron en cuenta los contenidos relativos con las informaciones, imágenes, opiniones y actitudes que presentan algunos operadores jurídicos de Organizaciones No Gubernamentales, ONG, y Centro Dignificar de la Localidad de Suba, que a través de la atención se encargan de gestionar el derecho de acceso a la justicia de indígenas víctimas de desplazamiento forzado procedentes de diversas regiones del país.

Los mencionados operadores jurídicos presentan factibilidad de aplicación de la teoría de las representaciones sociales propuestas por el psicólogo social Serge Moscovici (1961), en la medida que actúan y atienden a los indígenas afectados por el desplazamiento forzado según informaciones, imágenes, opiniones y actitudes que poseen sobre esta población. Por tratarse de un grupo que ostenta características similares debido a la función social y humanitaria que cumplen, es posible realizar exploraciones sobre las representaciones que presentan acerca de los grupos indígenas víctimas de desplazamiento forzado relacionados en procesos de atención, asistencia y/o reparación. Igualmente, analizar las opiniones que poseen algunos miembros de la etnia indígena Wounaan acerca del funcionamiento de los Centros Dignificar y de su acceso al sistema general de atención estatal.

El estudio de las representaciones sociales que poseen los operadores jurídicos acerca de los indígenas, es importante ya que estas pueden incidir de manera positiva o negativa en cuanto a la eficacia con la que los afectados pueden acceder a la justicia, 
influyendo de alguna manera en la salud mental de los indígenas, ya sea como operadores facilitadores de los procesos al ser empáticos frente a las necesidades de las víctimas, o como obstaculizadores al presentarse estigmatización y discriminación. A través del estudio de las representaciones sociales de algunos operadores jurídicos se pueden detectar posibles fallas en la implementación de protocolos, inexistencia de los mismos o falta de formación y capacitación adecuada. En tal sentido, es factible señalar estas situaciones para que posteriormente se puedan realizar aportes con el fin de dinamizar y mejorar la atención y la calidad del acceso a la justicia de los indígenas desplazados por la violencia, ubicados en la ciudad de Bogotá.

Esto es útil para visibilizar la problemática con la finalidad de que se logre optimizar la atención hacia los mismos. Igualmente, la teoría de las representaciones sociales se encuentra vigente dentro de la psicología, la sociología, la antropología y los estudios culturales y ha sido poco estudiada en nuestro país en lo concerniente con los operadores jurídicos que laboran en entidades gubernamentales y no gubernamentales que mantienen alguna clase de contacto con los grupos indígenas desplazados por la violencia y su derecho fundamental de acceso a la justicia. Tema que merece ser indagado en profundidad por la creciente cantidad de indígenas víctimas de este delito a causa del conflicto armado interno, lo que transgrede claramente los Derechos Humanos.

La Ley 599 de 2000 artículo 180, tipifica como perpetradores del delito de desplazamiento forzado a quienes "de manera arbitraria, mediante violencia u otros actos coactivos dirigidos contra un sector de la población, ocasione que uno o varios de sus miembros cambie el lugar de su residencia [...]", causando entre otros, la victimización de los afectados y la violación del Protocolo II de Ginebra que se aplica a 
los conflictos armados internos de los países. Precisamente, las representaciones sociales son un conjunto de conocimientos de sentido común que permiten interpretar y actuar ante la realidad (Moscovici, 1979; citado por Mora, 2002, p. 23). Pero a su vez las representaciones son campos de articulación de modos de producción, consumo y circulación de los conceptos que se convierten en políticas, en prácticas de poder en la vida cotidiana (Hall, 1997, p. 44)

En tal sentido, es importante analizar la presencia de opiniones, imágenes y actitudes existentes de los operadores jurídicos hacia los indígenas, y su acceso a la justicia, y así realizar aportes para mejorar futuros diagnósticos, pronósticos y programas de prevención referentes con la problemática del desplazamiento forzado, detectar falencias en la implementación de políticas públicas referentes a la atención de dicho fenómeno y evaluar la atención que ofrecen algunos operadores jurídicos a los miembros de grupos indígenas desplazados por la violencia situados en la capital del país.

Es importante llamar la atención y tomar consciencia sobre el modo en que algunos grupos indígenas se encuentran en riesgo de extinción, y que algunos cuentan con medidas cautelares proferidas por la Comisión Interamericana de Derechos Humanos, por tanto, es obligación de todos velar por la conservación de la diversidad étnica y cultural garantizando de manera efectiva sus derechos fundamentales, teniendo en cuenta el compromiso de hacer valer lo señalado por la misma Constitución Nacional de 1991, concerniente a que Colombia es una nación pluriétnica y multicultural.

De acuerdo al censo llevado a cabo por el Departamento Administrativo Nacional de Estadística, DANE, en 2005, en el país habitaban 1.392.623 indígenas, muchos de ellos en situación de desplazamiento forzado, que convivían en condiciones 
desfavorables sin acceso al mínimo vital ni garantías de bienestar y justicia. Estas comunidades pueden verse beneficiadas si los operadores jurídicos que laboran en las diferentes entidades son dotados con los suficientes medios logísticos, recursos económicos, la implementación de protocolos eficaces y la voluntad de servicio que les permita desarrollar un alto grado de empatía que estimule la protección del derecho al acceso de la justicia de estos ciudadanos, quienes varias veces se han visto segregados como si fueran invisibles y apátridas.

Mediante el cumplimiento de los deberes asignados en las diferentes entidades es factible brindarles el eficaz acceso a la justicia a través de los procesos de atención, asistencia y/o reparación, esforzándose por alcanzar relaciones más empáticas y equitativas, contribuyendo al mejoramiento de la calidad de vida de los grupos indígenas víctimas de desplazamiento forzado ubicados en Bogotá.

A través del análisis de las representaciones sociales evaluadas en la presente investigación, es posible la aplicación de algunos resultados para la facilitación del acceso a la justicia de las comunidades indígenas que se encuentran en la ciudad capitalina en situación de desplazamiento forzado, teniendo en cuenta que Bogotá es la fuente institucional de la generación e implementación de las leyes, políticas, planes, programas y proyectos de atención a la población desplazada.

El estudio de la información obtenida es útil para el descubrimiento de posibles falencias en la ejecución de las políticas públicas y de algunos operadores jurídicos que se encargan de atender a los indígenas víctimas de desplazamiento forzado, ya que de cierta manera están llamados a garantizar el derecho de acceso a la justicia, permitiendo vislumbrar a futuro la implementación de protocolos adecuados y el fortalecimiento de la empatía de los operadores jurídicos hacia los nombrados destinatarios de la justicia. 
De esta forma, la pregunta específica que encauza este estudio consiste en: ¿cuáles son las representaciones sociales en algunos operadores jurídicos e indígenas acerca del acceso a la justicia estatal de los indígenas afectados por el desplazamiento forzado? 


\section{Marco conceptual}

Acorde con lo descrito en el artículo octavo de la Declaración Universal de los Derechos Humanos (ONU, 1948) los Estados deben "garantizar a todos los habitantes del país, sin distinción de raza, credo, color, idioma [...] el derecho de acceder a la justicia en defensa de sus derechos fundamentales" (citado en Ferrer, 2010, p. 3). Este consiste, en la potestad de concurrir ante un juez para que garantice la protección de los derechos infringidos. Según Soto, (1998) “... de nada sirve pretender poseer un determinado derecho, si carece de la posibilidad de acudir al juez -esto es un órgano plenamente establecido, independiente e imparcial- que lo reconozca y le otorgue el amparo correspondiente... (Pág. 10)” .Igualmente, en la Carta Magna de 1991 los artículos 228 y 229, establecen que "la administración de justicia es una función pública" y se garantiza el derecho de todas las personas al acceso de la misma [...]. De acuerdo con lo establecido por la Corte Constitucional mediante Sentencia T-476/1998, el derecho de administración de acceso a la justicia es la garantía real y efectiva que el Estado le brinda a los ciudadanos para poder acudir ante el juez con el fin de que les solucione los litigios que surjan con otros individuos, con organizaciones y con instituciones del mismo Estado, debiendo el juez resolver las peticiones sin limitarse al simple trámite de solicitudes.

Cabe señalar, que la Corte Interamericana de Derechos Humanos efectúa una visión más amplia de los artículos 8 y 25, contenidos en la Convención Americana de los Derechos Humanos sobre el significado del derecho de acceso a la justicia, indicando que es un derecho el que permite llevar a la práctica otros derechos. Igualmente, menciona las obligaciones suscritas por varias naciones entre ellas Colombia, 
específicamente en los artículos 1.1 y 2 sobre la creación de mecanismos no solamente formales sino efectivos que produzcan efectos concretos, es decir, resultados $\mathrm{y}$ respuestas ante la vulneración de los derechos humanos. Igualmente, señala que el Estado debe proveer instancias de asistencia jurídica gratuita para las personas que por sus condiciones económicas se les dificulte la contratación de abogados que los representen (Informe anual sobre derechos humanos en Chile, 2007, p. 14)

Se define acceso a la justicia, como la existencia de facilidades para que todas las personas sin discriminación alguna puedan gozar de todos los recursos y servicios que garanticen su seguridad, movilidad, comunicación y comprensión de los servicios judiciales, que garanticen una justicia pronta y cumplida (CIDH, 2011, p. 105).

La Sentencia C- 163/1999 indica que para ejercer el derecho fundamental de acceso a la justicia es innecesario que todos los ciudadanos acudan ante los jueces a fin de resolver los conflictos, toda vez que para ello existen mecanismos alternativos que pueden emplear algunos operadores jurídicos, como la conciliación y el arbitraje de acuerdo a lo establecido en el artículo 116 de la Constitución Nacional, lo que coadyuva en la descongestión, la eficacia, efectividad y celeridad de la justicia estatal.

La Corte Constitucional a través de Sentencia 1027/ 02, ha expresado que el acceso a la administración de justicia se constituye para las personas en una necesidad inherente a su condición y naturaleza, porque sin este derecho se carecería de un instrumento para la convivencia armónica de la sociedad. En tal sentido, el acceso a la justicia es un servicio de carácter público, los operadores jurídicos como abogados, psicólogos, sociólogos, politólogos, trabajadores sociales, etc., que laboran en diferentes organizaciones no gubernamentales, ONG y gubernamentales como los 
"Centros Dignificar", son entidades distritales que cuentan con profesionales en áreas de la salud, derecho, educación, comunicaciones, etc., con el fin de brindar atención integral a la población en situación de desplazamiento forzado, las cuales se encuentran comprometidas en procurar el acceso a la justicia de los indígenas víctimas de este delito sociopolítico sin necesidad de tener que recurrir a mecanismos constitucionales como la tutela, para que se les garantice la vida digna (T-025 de 2004).

Es así como inicialmente la ley 387 de 1997, ordena a la administración pública la implementación de políticas y medidas para la atención integral, protección y prevención de desplazamientos forzados a raíz de la violencia existente en el país. Posteriormente, fue actualizada mediante la Ley 1448 de 2011, reglamentada a través del Decreto 4800 del mismo año, estableciendo diversos mecanismos y estrategias para tal fin. Cabe señalar, que el desplazamiento forzado es un delito que se encuentra tipificado en la Ley 599 de 2000 artículo 180, indicando como ejecutor de la conducta penal al que "de manera arbitraria, mediante violencia u otros actos coactivos dirigidos contra un sector de la población, ocasione que uno o varios de sus miembros cambie el lugar de su residencia [...]”. Es de anotar, que la ley 1448 de 2011 no se enfocó en el tema de las comunidades indígenas víctimas del conflicto armado interno, por tal razón, el gobierno nacional expidió el Decreto Ley 4633 de 2011 que trata de la atención, asistencia, reparación integral y restitución de los territorios de los pueblos indígenas, quienes se encuentran cobijados por el enfoque diferencial étnico.

De manera específica, el artículo séptimo de la Carta Magna contempla que: "El Estado reconoce y protege la diversidad étnica y cultural de la Nación Colombiana", naciendo así, el principio constitucional que demanda la expedición de medidas diferenciales que reconozcan la identidad propia de los pueblos indígenas. 
El enfoque diferencial es el reconocimiento de que existen poblaciones que por sus características particulares, en razón de su edad, género, orientación sexual, grupo étnico y situación de discapacidad, deben recibir un tratamiento especial en materia de ayuda humanitaria, atención, asistencia y reparación integral (UARIV, 2014, p. 2)

El enfoque diferencial, pretende restituir los derechos de las víctimas afectadas por el conflicto armado interno, teniendo en cuenta sus particularidades, su diversidad y vulnerabilidad.

Para efectos de este trabajo, los operadores jurídicos están constituidos por aquellos profesionales de diferentes disciplinas tales como abogados, sociólogos, politólogos, psicólogos, trabajadores sociales, etc., que efectúan prácticas asistenciales humanitarias en instituciones gubernamentales y no gubernamentales atendiendo el fenómeno del desplazamiento forzado de los grupos indígenas. Peces- Barba (1987) señala que estos operadores son un "genérico que identifica a todos los que con una habitualidad profesional, se dedican a actuar en el ámbito del Derecho, [...] y se diferencian precisamente por ese papel, que caracteriza su actividad del común de los ciudadanos" (pág. 448). Tal como sucede con los operadores jurídicos que se encargan de la aplicación de las leyes creadas para atender a los diferentes grupos indígenas víctimas de desplazamiento forzado y por ende garantizar su derecho de acceso a la justicia.

Pierre Bourdieu (2002) citado en Jaraba (s.f.), autor de la "teoría de la acción práctica", es un estudioso de la sociología de la cultura, entre otras cosas, afirma que existen estructuras sociales jerarquizadas, evidenciándose relaciones de poder entre dominados- dependientes, con la anuencia de estos últimos; donde los funcionarios 
que ejercen sus prácticas en diferentes campos (político, jurídico, educativo, salud), imponen sus creaciones simbólicas y culturales (Pág. 9). Igualmente, señala que la violencia simbólica es todo poder que impone significaciones como legítimas disfrazando relaciones de fuerza (Gutiérrez, 2004, p. 11), tal como sucede con algunos miembros de los grupos indígenas víctimas de desplazamiento forzado que al tratar de acceder a la justicia estatal se ven sometidos por el sistema judicial al cumplimiento de ciertos requisitos formales contemplados en las leyes.

Bourdieu, (citado por Gutiérrez, 2004) empleó el concepto de Hábitus aludiendo a la manera de sentir, de actuar y de pensar de los individuos en el ámbito social, de acuerdo con la posición que ocupan dentro de la mencionada estructura. De igual manera, manifiesta sobre el capital, que existe una competencia por los recursos simbólicos y materiales; en donde el capital simbólico está constituido por las propiedades personales inherentes a los agentes-en este caso operadores jurídicos- tales como el prestigio, la reputación, la autoridad etc., y que con el trascurrir del tiempo las personas van acumulando conocimientos, creencias y destrezas que hacen parte del capital simbólico, es decir, que este se constituye en poder. "Lejos de ser naturales o inherentes a la persona misma, tales propiedades sólo pueden existir en la medida en que sean reconocidas por los demás” (Giménez, 1997, p.15).

De la misma manera, las representaciones sociales se establecen como una forma de poder debido a que son instrumentos de comunicación y de conocimiento que estructuran la construcción de la realidad implantando orden y sentido al mundo, lo que genera un juego entre quienes poseen el capital simbólico y los que desean obtenerlo ( Gutiérrez, 2004, p.8). 
Hall (1997) en su escrito "El trabajo de la representación" refiere que Foucault, realizó aportes a la teoría de las representaciones, indicando que las relaciones entre el saber y el poder se dan en el conocimiento y las prácticas cotidianas, empleando para ello el concepto de discurso como un referente más amplio que el de lenguaje, señalando la existencia de una relación entre el saber, el discurso y el poder. En la práctica el saber cotidiano y el conocimiento especializado determinan la conducta social (Pág. 26).

Foucault se preocupó aún más con el hecho de cómo el conocimiento opera mediante prácticas discursivas en contextos institucionales específicos para regular la conducta de los otros. Enfocó la relación entre conocimiento y poder, y cómo el poder opera dentro de lo que él llamó un aparato institucional y sus tecnologías (Hall, 1997, P. 30).

Teniendo en cuenta los órdenes discursivos propuestos por Michel Foucault, entre ellos: la construcción de la verdad y la organización disciplinar de los saberes, como los rituales de los miembros que pertenecen a las instituciones y organizaciones discursivas, se puede señalar que las prácticas de asistencia humanitaria que emplean los operadores jurídicos y su discurso, se convierten en un modo de saber que genera poder hacia los grupos indígenas en situación de desplazamiento forzado (Foucault, 1980; citado en Hall, 1997, p. 35).

Aplicar o no la ley es la muestra de cómo se establecen las relaciones de poder dentro de las instituciones en general. En el proceso de atención a los afectados se presenta un choque entre las representaciones de los indígenas y los discursos de los operadores jurídicos, que perduran por medio de protocolos y reformas jurídicas que a 
su vez tienen consecuencias en la subjetividad de las personas aquejadas por dichos crímenes.

Cabe indicar, que conforme con lo establecido en la hoy en boga justicia transicional, las instituciones gubernamentales deben garantizar la continuidad de las políticas de atención, asistencia y reparación integral de los indígenas en situación de desplazamiento forzado, para que se encuentren vigentes las normas que las reglamentan, a fin de que en la práctica exista el Estado, no sólo en la letra.

De esta manera, los operadores jurídicos empleando las representaciones, el saber, el poder y el discurso, pueden respetar o cambiar la cosmovisión de los indígenas víctimas de desplazamiento forzado. Igualmente, los indígenas cambian la visión del mundo de los operadores jurídicos, mediante el empleo de intercambios culturales.

El tema de las representaciones surge con la "Teoría de las ideas" de Platón, término que procede del latín "reapresentare" que significa "hacer presente en cierto sentido, algo que literalmente no está presente" (RAE, 2010). En la actualidad, no existe un consenso acerca de la definición de las representaciones sociales debido a los continuos debates que se presentan entre la psicología social, la sociología y otras ciencias sociales (Jahoda, 1988; citado en Mireles, 2011, p. 13). La teoría de las representaciones sociales se viene estudiando dentro de la psicología social durante los últimos años para tratar de comprender e interpretar la relación entre la subjetividad social e individual de los diferentes grupos. En tal sentido, los individuos construyen sus conocimientos dependiendo de sus contextos sociales. "Las RS son vistas como esquemas mentales o imágenes que la gente utiliza para dar sentido al mundo y para 
comunicarse con los demás. Este concepto ofrece un nuevo marco para comprender la organización de las actitudes, creencias, y atribuciones...” (Moñivas, 1994, p. 418).

La concepción de la representación social surgió en Francia después de la segunda guerra mundial, y fue propuesta por el psicólogo Serge Moscovici (1961), quien presentó como tesis doctoral "El psicoanálisis, su imagen y su público" donde entre otros objetivos, quiso investigar acerca de la manera como los franceses ven el psicoanálisis; "El interés de Moscovici se centra en comprender los modos de conocimiento, entender cómo el saber científico es transformado en saber popular, en conocimiento del sentido común que orienta las comunicaciones y prácticas” (Banchs, 2000; en Rodríguez y García, 2007, p. 87).

Las representaciones sociales son aquí complementadas con las ideas que introducen los estudios genealógicos de Foucault y los estudios culturales de Stuar Hall, donde las representaciones con o sin apellido social o cultural son el medio de circulación de las ideas, de las ideologías y de los poderes, de las prácticas de dominación, de control, de disciplinamiento, de seducción, de consentimiento, de oposición, de resistencia, conflicto y lucha (Ball, 1993, p. 7-10).

De tal manera, para el estudio de las representaciones sociales es necesario tener en cuenta la información que poseen los operadores jurídicos, el contenido de los relatos y las diferentes posturas que toman frente al fenómeno del desplazamiento forzado de los grupos de indígenas. Igualmente, podemos señalar como un elemento relevante de carácter psicosocial y psicojurídico el que Moscovici señala como fue influenciado por el sociólogo Emile Durkheim y su teoría sobre "Las representaciones colectivas" (Moscovici, 1979; citado en Mora, 2002, p. 10). Durkheim, consideraba las leyendas, los mitos populares, las creencias morales y religiosas como representaciones 
colectivas. De igual manera, afirmó que constituyen "el acervo de conocimiento simbólicamente estructurado de una sociedad" (Palacios, 2012, p.12)

Una de las principales diferencias entre la teoría de Moscovici y lo descrito por el sociólogo Emile Durkheim consiste en que este último estudió las representaciones colectivas de forma generalizada y dinámica, mientras la teoría de las representaciones sociales se esfuerza en explicar el comportamiento humano a través de la exploración de las creencias y vivencias de los protagonistas, compartidas por determinados grupos e individualmente de manera fragmentada. A través del estudio de los procesos de carácter simbólico y de las relaciones interpersonales se muestra el discurso del sentido común el cual construye teorías o ramas de conocimiento propias, -saberes apropiados socialmente-, ya que las representaciones sociales constituyen un sistema cognitivo que posee lógica y lenguaje singular, (Moscovici, 1961, p. 16).

Hall (1997) en el texto "El trabajo de la representación” asegura como lo hemos mencionado bajo la tradición de Foucault, que las representaciones son prácticas y “procesos mediante los cuales los significados se producen e intercambian entre quienes conforman una cultura, constituyen la producción de sentido de los conceptos en nuestras mentes a través del lenguaje” (Pág. 2). Prácticas que crean los sistemas conceptuales conformados por dos procesos; un sistema que tenemos en nuestras cabezas que se encarga de establecer semejanzas y diferencias entre los conceptos que poseemos de las situaciones, personas y objetos. El otro denominado "sistema de representación" que permite a los grupos sociales formarse conceptos de cosas que no pueden verse ni tocarse puesto que son abstractas (Hall, 1997, P. 4)

En tal sentido, utilizamos signos y códigos que sirven para organizar la información y la manera de compartirla se hace mediante el empleo del lenguaje. Este 
mismo autor, aludiendo al "enfoque construccionista del sentido" indica que las cosas no significan por sí mismas sino que construimos el sentido empleando el sistema de representaciones que tienen verificación en la acción práctica. Por esta razón, las representaciones son relativas en cuanto que varían de acuerdo a las diferentes culturas, a los contextos, haciéndose necesaria su traducción a medida que nos trasladamos de una cultura a otra, de una nación a otra.

Existen otros autores destacados en la investigación de las representaciones sociales que es necesario mencionar antes de culminar este apartado, y que han realizado aportes significativos tales como: Jodelet 1986; Doise 1984; Abric 2001; Banchs 2000; Ibáñez 1988; Berger y Luckman 2001; Farr 1982. Cabe aclarar, que por su finalidad este estudio desatiende las discusiones y las diversas críticas efectuadas a la teoría de las representaciones sociales propuesta por Serge Moscovici.

Para delimitar los usos de este término en el presente trabajo, se define como representaciones sociales:

A la modalidad particular del conocimiento -conocimiento del sentido común-, cuya función es la elaboración de los comportamientos y la comunicación entre los individuos. Así como un "corpus" organizado de conocimientos y una de las actividades psíquicas gracias a las cuales los hombres hacen inteligible la realidad física y social, se integran en un grupo o en una relación cotidiana de intercambios, liberando los poderes de su imaginación (Moscovici, 1979, P. 1718; citado en Mora, 2002, p.7).

Las representaciones sociales de Moscovici son sistemas cognitivos con una lógica y un lenguaje propio. No representan simplemente opiniones acerca de 
"imágenes de", "actitudes hacia", sino que representan "teorías o ramas del conocimiento" (Zamora, 2007, P. 25).

Las representaciones sociales, RS, como sistemas sociales de valores, ideas y prácticas, cumplen dos funciones: orden y comunicación. En la concepción de Moscovici se plantean cuatro elementos constitutivos de las RS: La información, que se relaciona con lo que "yo sé"; la imagen que se relaciona con lo que "veo"; las opiniones, con lo que "creo"; las actitudes, con lo que "siento", elementos que tomamos como guía para el análisis de las representaciones sociales (Zamora, 2007, p. 25). A lo que sumamos, intercambios de poder en las relaciones sociales a la luz de Stuart Hall, Michel Foucault y Pierre Bordieu anteriormente presentados.

Apoyado en esta definición se pretende examinar los relatos de sentido común en busca de informaciones, imágenes, opiniones y actitudes en los niveles individuales y sociales de ciertos operadores jurídicos que laboraron en instituciones gubernamentales (Centro Dignificar de la Localidad de Suba) y entidades no gubernamentales ubicadas en Bogotá, brindando atención y asistencia para garantizar el acceso a la justicia de los miembros de pueblos indígenas víctimas de desplazamiento forzado.

Para reafirmar la concepción del proyecto, Jodelet (1986) afirma que las representaciones sociales son "formas de conocimiento social", donde los individuos aprehenden la realidad (Citado en Rodríguez y García, 2007, p. 102). Estas autoras señalan que el conocimiento es comunicado a los otros a través de imágenes, creencias y otras expresiones que se comparten socialmente por los grupos sin necesidad de que se conozcan personalmente, siendo un conocimiento heredado que salta del plano individual al grupal y luego al social. Las representaciones sociales están regidas por 
procesos de anclaje y objetivación que sirven para su formación y organización; el anclaje es un proceso mediante el cual se categorizan los individuos y las cosas permitiendo transformar lo desconocido en algo propio que es comunicado en el sentido común, la objetivación es un proceso que permite convertir las entidades abstractas en algo definido que predomina en la cotidianidad haciéndolo habitual (Moscovici, 1984, p. 34)

Consideramos como supuesto de la reflexión que los operadores jurídicos pertenecientes a las organizaciones gubernamentales y no gubernamentales, son grupos de profesionales que no escapan a las representaciones sociales propuestas por Moscovici, a los conocimientos heredados, a los hábitus planteados por Bordieu, a las representaciones culturales propuestas por Stuart Hall o al orden discursivo señalado por Michell Foucault. Estos operadores trabajan mancomunadamente con la finalidad de alcanzar objetivos similares, cumpliendo disposiciones contempladas en la ley, y de paso llevan consigo ciertos prejuicios sociales históricamente constituidos que cargan los "blancos" o mestizos sobre los indígenas, en medio de un choque histórico y cultural que no se ha resuelto.

De igual manera, dichos operadores al haber laborado en la capital y algunos de ellos en las zonas de conflicto, han presenciado las condiciones en que se encuentran algunos pueblos indígenas en situación de desplazamiento forzado ubicados en Bogotá, ya que muchos de estos deambulan o ejercen actividades como la mendicidad, lo que los convierte en testigos oculares de las consecuencias del fenómeno nombrado.

Es necesario aclarar, que en esta investigación no se hace referencia a la migración interna voluntaria que se realiza dentro del país o la movilización externa hacia otras naciones que realizan ciertas personas con el fin de buscar mejores 
condiciones de vida, sino al fenómeno del desplazamiento forzado descrito en Ley 387 de 1997 , artículo $1^{\circ}$, que consiste en "toda persona que se ha visto forzada a migrar dentro del territorio nacional $[\ldots]$ porque su vida, su integridad física, su seguridad o libertad personales se encuentran directamente amenazadas $[\ldots]$ por el conflicto armado interno, disturbios y tensiones interiores $[\ldots]$ ". Tal como sucede con varios pueblos indígenas que se ven obligados a huir de sus resguardos por amenazas de diferentes grupos armados, desterrados a fin de preservar sus vidas; desplazándose inicialmente hacia las cabeceras municipales y luego terminan en las principales ciudades del país como Bogotá, ya que son varios los que creen que les van a dar respuesta a sus problemas en la ciudad capital. Lo que configura el delito por desplazamiento forzado descrito en la Ley 599 de 2000, artículo 180. Cabe resaltar, que se considera indígena "aquella persona que hace parte de una comunidad o pueblo indígena, se identifica con sus costumbres, lengua y tradiciones, reconoce las autoridades tradicionales y formas de gobierno propio" (Del Popolo, 2005; citado en Montero, s.f., p. 27)

De acuerdo con informes de pobreza (2004) revelados por la Organización de las Naciones Unidas, ONU, en Latinoamérica residen entre 40 a 50 millones de indígenas lo que equivale al 10\% de los habitantes de la región, en Perú y Bolivia constituyen el 50\% de su población total (Montero, s.f., 18). Según el Departamento Administrativo Nacional de Estadística, (DANE, 2005) en Colombia todos los departamentos conservan comunidades indígenas, durante el último censo realizado en el año 2005, la población nombrada constaba de 1.392 .623 personas correspondientes al $3.43 \%$ de la población total del país, los departamentos donde mayor población indígena se aglutinaba eran Vaupés 66. 65\%, Guainía 64.90\%, La guajira 44.94\%, Vichada 44.35, Amazonas $43.43 \%$, Cauca $21.55 \%$ y Putumayo son $20.94 \%$.En total existían 87 etnias y 
710 resguardos distribuidos en 27 departamentos. Para efectos de realizar el censo de manera práctica y confiable conformaron seis regiones ver (Tabla 1)

Tabla 1.

División etnográfica indígena en el censo 2005.

\begin{tabular}{|c|c|}
\hline Región etnográfica & Grupos étnicos en los territorios \\
\hline Región Norte & Waviu, arhuaco, wiva. koqui, kankuamo, chimilas, yukos, zenú \\
\hline Región Noroccidental & $\begin{array}{l}\text { Zenú, embera katio, embera chami, embera waunan, tule, kuna, eperara } \\
\text { siapirara. }\end{array}$ \\
\hline Región Centroriental & Uwa, motilón bari, quahibo, sicuani, piapoco, auba y macahuan. \\
\hline Región Suroccidental & $\begin{array}{l}\text { Waunan, paez, guambianos yanaconas, awa, pastos, ingas, quillacinga, } \\
\text { kam'tza, siona, kofan, eperara siapirara, embera. }\end{array}$ \\
\hline Región Centroccidental & Embera Chami, Pijao. \\
\hline Región Oniental & $\begin{array}{l}\text { Sikuani, piapoco, piaroa, salivas, curripaco, puinave, guayabero, tucano } \\
\text { desano, kubeo, mintiti - parana - matapi, yukuna, tikuna, coreguaje, } \\
\text { muinane, tanimuca, cocama, witoto, inga, paez, andoque, cuba, saliva, } \\
\text { nukak makj. }\end{array}$ \\
\hline
\end{tabular}

Fuente: Documento de trabajo. Censo en territorios étnicos DANE, 2005.

De acuerdo con las cifras registradas en el DANE, durante el censo de 2005, la población indígena que habitaba en Bogotá era de 15.032 personas, los cabildos más significativos pertenecían a la comunidad de los Muiscas que se encuentran radicados en la localidad de Suba, conformada por 5.000 indígenas y en la localidad de Bosa con aproximadamente 3.000. Cabe anotar, que las cifras de indígenas víctimas de desplazamiento por la violencia residentes en Bogotá, varían constantemente debido a que está conformada por población nómada, móvil o "flotante”.

Conforme a lo descrito por Sánchez (2007) la etnia de los indígenas Wounaan se encuentra en peligro de extinción a causa de la presencia de los diferentes actores armados, habitan en la zona limítrofe del Darién entre el departamento del Chocó y la 
república de Panamá, se dedican a la agricultura, caza y pesca. Conviven en casas hechas de paja circulares en forma de cono. Las mujeres se encargan de la recolección de los cultivos de arroz, yuca, fríjol, maíz, plátano y caña de azúcar. Estas hablan poco, manteniendo un rol subordinado ante la prevalencia de los hombres. Su población se calcula en 14.500 habitantes, los cuales migran entre Colombia y Panamá, se expresan en dialecto Maach meu, algunos de ellos hablan el idioma español. En cuanto a su cosmovisión consideran que los espíritus permanecen directamente conectados con la naturaleza y controlan los sufrimientos físicos y el bienestar personal (Pág. 13-19)

Según La Unidad de Atención y Reparación Integral a la Víctimas, UARIV, entidad adscrita al Departamento para la Prosperidad Social, DPS, y el Registro Único de Población Desplazada, RUPD, a febrero de 2011 se encontraban registrados en Bogotá 7.288 indígenas desplazados por la violencia. Es oportuno señalar, que los indígenas en situación de desplazamiento forzado, para ser incluidos en el Registro Único de Víctimas, ordenado mediante Ley 387 de 1997, deben seguir una ruta de atención cumpliendo con ciertos requisitos contemplados en el Decreto 2569 de 2000.

El artículo 154 de la Ley 1448 de 2011, manifiesta que la Unidad Administrativa Especial para la Atención y Reparación de Víctimas, es la responsable del funcionamiento del registro Único de Víctimas. Los desplazados han de acudir al ministerio público; la Defensoría del Pueblo, Procuraduría General de la Nación o Personerías que en la actualidad funcionan dentro de los "Centros Dignificar" para efectuar la declaración de modo, tiempo y lugar de los hechos del desplazamiento forzado, recibiendo mientras tanto ayuda humanitaria de emergencia, después de cuarenta y cinco días de valoración por parte de los operadores jurídicos que laboran en el Departamento para la Prosperidad Social, DPS, deben asistir a cualquiera de los 
Centros Dignificar ubicados en las localidades de Ciudad Bolívar, Bosa-Kennedy, Puente Aranda, Suba, Ciudad Bolívar, Rafael Uribe Uribe y Terminal de Transportes, para conocer el resultado de la valoración, donde les comunicarán si han sido incluidos en el Sistema de Información de Población Desplazada (SIPOD).Convirtiéndose en receptores de diferentes ayudas, como entrega de bonos alimentarios que pueden ser reclamados en varios centros comerciales y supermercados de cadena, estadía en albergues temporales y varios subsidios hasta que les sean restituidos los derechos vulnerados.

En Colombia existe teóricamente, un ordenamiento jurídico y la denominada justicia transicional la cual determina la aplicación de diversas medidas con el fin de reparar a las víctimas de las transgresiones de los derechos humanos, entre ellos se encuentran los indígenas víctimas de desplazamiento forzado, pero a continuación señalaremos que es común observar como son continuamente victimizados de manera individual y colectiva, recibiendo atención inadecuada en aspectos de vivienda, salud, educación, alimentación y tardanza en la ejecución de los procesos judiciales. Estos procesos en nuestro país son dilatorios, enredados y victimizantes, los cuales pueden terminar en detrimento de las víctimas de desplazamiento, ya que no brindan las suficientes garantías de acceso a la justicia (Tapias, 2011; citado en Hernández, 2011, p.26), dando la percepción de que las víctimas se encuentran desprotegidas y olvidadas por parte de las instituciones del Estado, desconociendo la práctica del enfoque diferencial que hace referencia a que se debe tener en cuenta las características socioculturales especiales de los grupos étnicos, referidas en los artículos primero y séptimo de la Carta Magna. 
La Constitución Nacional (1991) artículo 246, respecto al derecho de autonomía, indica que "las autoridades de los pueblos indígenas podrán ejercer funciones jurisdiccionales dentro de su ámbito territorial, de conformidad con sus propias normas y procedimientos, siempre que no sean contrarios a la Constitución y leyes de la República [...]”. De igual manera, los artículos 286 y 329 establecen que los territorios indígenas son entidades territoriales, de carácter jurídico y colectivo, "los resguardos son de propiedad colectiva y no enajenable". El artículo 330 señala que los territorios indígenas serán gobernados por los concejos conformados de acuerdo a las costumbres de sus comunidades, los cuales tienen varias funciones como velar por el mantenimiento del orden público, conservación de los recursos naturales, percibir y distribuir los recursos.

De esta forma, la Ley 387 de 1997 trata de la implementación de "medidas para la prevención del desplazamiento forzado; la atención, protección, consolidación y estabilización socioeconómica de las personas víctimas de este flagelo a causa del conflicto armado en la República de Colombia”, en su artículo primero hace alusión a la atención especial para los indígenas teniendo en cuenta sus usos, costumbres y el retorno a sus territorios. También, la sentencia T-025 de 2004, con sus respectivos autos de seguimiento, en especial el auto 004 de 2009, ordena la adopción de medidas para la protección de los derechos fundamentales de los indígenas víctimas del desplazamiento forzado, haciendo énfasis en la atención integral diferencial y garantía de los derechos a la verdad, justicia, reparación y garantía de no repetición. Del mismo modo, la Ley 975 de 2005 artículo 5 define víctima como "la persona que individual o colectivamente haya sufrido daños lesiones transitorias o permanentes [...] menoscabo de sus derechos fundamentales. [...] consecuencia de acciones que hayan transgredido la legislación penal, realizadas por grupos armados organizados al margen de la ley". Esta misma 
norma en el artículo $6^{\circ}$ manifiesta sobre el Derecho a la justicia que "el Estado tiene el deber de realizar una investigación efectiva que conduzca a la identificación, captura y sanción de las personas responsables de delitos cometidos por los miembros de grupos armados al margen de la ley" asegurándoles la no repetición de los hechos y la reparación integral por los daños causados.

Conforme con la ley 975 de 2005 artículo $7^{\circ}$, las víctimas tienen derecho a conocer la verdad sobre delitos cometidos por grupos al margen de la ley como secuestro y desapariciones forzadas. En cuanto al Derecho a la reparación el artículo $8^{\circ}$ indica que "la reparación comprende las acciones que propendan por la restitución, indemnización, rehabilitación, satisfacción; y las garantías de no repetición de las conductas". Igualmente, la Ley 1448 de 2011 hace referencia a las "medidas de atención, asistencia y reparación integral a las víctimas del conflicto armado interno”, en el artículo $2^{\circ}$ establece el respeto a los usos, costumbres y colectividad de los indígenas, al igual que el artículo 205, hace alusión a la restitución de tierras pertenecientes a los grupos indígenas y la implementación de una política pública diferencial para las víctimas pertenecientes a las nombradas comunidades víctimas de desplazamiento forzado. También, el Decreto Ley 4633 de 2011, en el artículo $3^{\text {o }}$ indica que "se consideran víctimas a los pueblos y comunidades indígenas como sujetos colectivos y a sus integrantes individualmente, que hayan sufrido daños como consecuencia de violaciones graves y manifiestas de normas internacionales de Derechos Humanos, derechos fundamentales y colectivos [...]". Este mismo decreto ley en el capítulo segundo, trata sobre el enfoque diferencial al interior de los pueblos indígenas, otorgando prevalencia a los derechos de los niños, adolescentes, discapacitados, mujeres embarazadas y personas de la tercera edad. 
Actualmente, en Bogotá existen siete Centros Dignificar y varias organizaciones no gubernamentales de asistencia humanitaria, algunas conformadas por voluntarios que tienen entre otros objetivos gestionar la atención, la defensa de los derechos fundamentales y el acceso a la justicia de las comunidades indígenas en situación de desplazamiento forzado, algunas de ellas reciben apoyo económico de la comunidad internacional, de empresas privadas o de parte del gobierno (Pérez, 2006, p. 8). En este orden de ideas, las Organizaciones No Gubernamentales, ONG, por tratarse de organizaciones sociales se encuentran jurídicamente amparadas en el libre derecho de asociación descrito en los artículos 38 y 39 de la Constitución Nacional (1991), las cuales pueden obtener su personería jurídica acudiendo a las Cámaras de Comercio existentes en toda la nación. Las diferentes -ONG-son organizaciones privadas sin ánimo de lucro, de carácter autónomo e independiente del Estado, las cuales son instituidas por personas jurídicas o naturales encargadas de efectuar actividades de apoyo social, que contribuyen con el progreso y mejoramiento de la calidad de vida de la sociedad (Revilla, 2002, p. 73). Sin embargo, las diversas -ONG- no reemplazan las acciones del Estado en cuanto a la implementación de políticas públicas, en teoría, se encargan de ejercer presión fiscalizando y proponiendo nuevas leyes que promuevan la rendición de cuentas y la participación ciudadana de acuerdo con los principios democráticos (Pérez, 2006, p. 39).

Bajo estos referentes institucionales, jurídicos, conceptuales e histórico culturales, el presente estudio tiene como objetivo analizar las representaciones sociales de algunos operadores jurídicos gubernamentales y no gubernamentales que laboraron en Bogotá, como de indígenas, frente al acceso a la justicia de los grupos étnicos en situación de desplazamiento forzado. 


\section{Categorías de análisis}

La presente investigación fue de tipo descriptivo en el nivel de la recolección. Para la construcción de las categorías preestablecidas, se recurrió a los antecedentes consignados en el marco teórico, teniendo en cuenta los tópicos más sobresalientes que deberían ser investigados, con la finalidad de alcanzar el objetivo de la investigación.

Inicialmente, se determinaron las siguientes categorías preestablecidas: derecho de acceso a la justicia, desplazamiento forzado, víctima, implementación de las leyes, atención, asistencia y reparación de indígenas y derecho a la justicia. Posteriormente, con el apoyo del programa Atlas.Ti, se realizó la codificación axial, abierta y selectiva de los relatos de los participantes, emergiendo a partir de la categoría central "Representaciones sociales de operadores jurídicos e indígenas sobre el acceso a la justicia de los grupos étnicos", las siguientes categorías: derecho de acceso a la justicia, enfoque diferencial, atención a indígenas, vulneración de derechos y victimización secundaria. A continuación se describe el contenido de referencia de cada una de ellas:

\section{Categoría 1: Representaciones sociales}

Las RS constituyen la modalidad particular del conocimiento -conocimiento del sentido común-, cuya función es la elaboración de los comportamientos y la comunicación entre los individuos. Así como un "corpus" organizado de conocimientos y una de las actividades psíquicas gracias a las cuales los hombres hacen inteligible la realidad física y social, se integran en un grupo o en una relación cotidiana de intercambios, liberando los poderes de su imaginación (Moscovici, 1979, P. 17-18; citado en Mora, 2002, p.7). 
Las representaciones sociales de Moscovici son sistemas cognitivos con una lógica y un lenguaje propio. No representan simplemente opiniones acerca de "imágenes de", "actitudes hacia", sino que representan "teorías o ramas del conocimiento" (Zamora, 2007, P. 25).

\section{Categoría 2: Derecho de acceso a la justicia}

“Toda persona tiene derecho, en condiciones de plena igualdad, a ser oída públicamente y con justicia por un tribunal independiente e imparcial, para la determinación de sus derechos y obligaciones [...]" (Declaración Universal de los Derechos Humanos, artículo 10)

“Las víctimas serán tratadas con compasión y respeto por su dignidad. Tendrán derecho al acceso a los mecanismos de la justicia y a una pronta reparación del daño que hayan sufrido, conforme lo dispuesto en la legislación nacional” (ONU, Resolución, 4034).

La Corte Interamericana de Derechos Humanos efectúa una visión más amplia de los artículos 8 y 25, contenidos en la Convención Americana de los Derechos Humanos sobre el significado del derecho de acceso a la justicia, indicando que es un derecho que permite llevar a la práctica otros derechos. Igualmente, menciona las obligaciones suscritas por varias naciones entre ellas Colombia, específicamente en los artículos 1.1. Y 2 sobre la creación de mecanismos no solamente formales sino efectivos que produzcan efectos concretos, es decir, resultados y respuestas ante la vulneración de los derechos humanos (Informe anual sobre derechos humanos en Chile, 2007)

Se define acceso a la justicia, como la existencia de facilidades para que todas las personas sin discriminación alguna puedan gozar de todos los recursos y servicios que garanticen su seguridad, movilidad, comunicación y comprensión 
de los servicios judiciales, que garanticen una justicia pronta y cumplida (CIDH, 2011, p. 105).

\section{Categoría 3: Enfoque diferencial}

Surge a partir de la Constitución Nacional de 1991, ya que en el artículo séptimo hace referencia a la pluralidad de personas existentes dentro del territorio colombiano.

El enfoque diferencial es el reconocimiento de que existen poblaciones que por sus características particulares, en razón de su edad, género, orientación sexual, grupo étnico y situación de discapacidad, deben recibir un tratamiento especial en materia de ayuda humanitaria, atención, asistencia y reparación integral (UARIV, 2014, p. 2)

El enfoque diferencial, pretende restituir los derechos de las víctimas afectadas por el conflicto armado interno, teniendo en cuenta sus particularidades, su diversidad y vulnerabilidad.

\section{Categoría 4: Atención a indígenas}

El Estado colombiano informará y asesorará a las víctimas [...] sobre los derechos, recursos y de todos los servicios jurídicos, médicos, psicológicos, sociales, administrativos y de otra índole a los que pueden tener derecho, teniendo en cuenta las características ancestrales de cada pueblo, así como el idioma de las víctimas. Los pueblos indígenas accederán a los medios de información para divulgar los derechos... (Decreto Ley 4633 de 2011, art. 40)

\section{Categoría 5: Vulneración de los Derechos Humanos}

"Los Derechos Humanos son derechos inherentes a todos los seres humanos, sin distinción alguna de la nacionalidad, lugar de residencia, sexo, origen nacional o étnico, color, religión, lengua o cualquier otra condición" (ONU, 2010) entre ellos se encuentra 
el derecho a la vida, a la libertad, a la diversidad étnica y cultural, a la justicia, al territorio, acceso a la justicia etc. En tal sentido, la vulneración de los mismos consiste en contravenir o incumplir lo establecido en la Constitución Nacional, en convenios y tratados internacionales suscritos por Colombia

\section{Categoría 6: Victimización secundaria}

Según Echeburúa, Corral y Amor (2004) es toda acción u omisión que empeore el estado físico y/o psíquico de la víctima cuando busca ayuda y se relaciona con el sistema legal, instancias en las que puede encontrar insensibilidad, incomprensión, nuevas agresiones, que se le ponga en tela de juicio, dilaciones, falta de información (Tapias, 2011; citado en Hernández, 2011, p. 26)

Todas las categorías fueron evaluadas a través de la entrevista semiestructurada (Ver anexo 1) 


\section{Objetivo general}

\section{Objetivos}

Analizar las representaciones sociales de algunos operadores jurídicos que laboraron en diferentes entidades gubernamentales y no gubernamentales de Bogotá, e indígenas, sobre el acceso a la justicia estatal de los grupos étnicos en situación de desplazamiento forzado.

\section{Objetivos específicos}

1. Ilustrar representaciones sociales de operadores jurídicos que laboraron en entidades gubernamentales y no gubernamentales de Bogotá, e indígenas en situación de desplazamiento forzado, acerca del acceso a la justicia estatal.

2. Relacionar elementos de representaciones sociales en algunos operadores jurídicos que laboraron en entidades gubernamentales y no gubernamentales de Bogotá, e indígenas en situación de desplazamiento forzado, acerca del acceso a la justicia estatal. 


\section{Método}

\section{Tipo de investigación y diseño}

Esta investigación de tipo cualitativa, descriptiva, se enmarcó dentro de la teoría fundamentada (Grounded Theory, 1967) propuesta por Glaser y Strauss, diseño sistemático cuyo procedimiento se lleva a cabo a través de la codificación axial, abierta y selectiva de los datos (Hernández, Fernández y Baptista; 2010, p.688). Cabe aclarar que: "Los diseños cualitativos son flexibles y abiertos, y su desarrollo debe adaptarse a las circunstancias del estudio. [...] Cada estudio cualitativo es por sí mismo un diseño de investigación” (Hernández y cols, 2010, p. 685). De esta manera, se pretendió analizar las representaciones sociales de algunos operadores jurídicos que laboraron en varias ONG de Bogotá, y operadores gubernamentales pertenecientes al "Centro Dignificar" de la Localidad de Suba, e indígenas víctimas de desplazamiento forzado miembros de la etnia indígena Wounaan, procedentes de diversos resguardos ubicados en el departamento del Chocó, que en la actualidad residen en la Localidad de Ciudad Bolívar, acerca del acceso a la justicia de los grupos étnicos nombrados.

\section{Participantes}

La muestra intencional de esta investigación fue constituida por doce (12) participantes hombres y mujeres adultos, de los cuales ocho (8) son profesionales de diferentes ciencias y disciplinas tales como abogados, politólogos, psicólogos, trabajadores sociales, etc., que orientaron o atendieron miembros de grupos indígenas víctimas de desplazamiento forzado en procesos de atención, asistencia y/o reparación, en Organizaciones No Gubernamentales y en el Centro Dignificar de la Localidad de Suba. Y cuatro (4) indígenas hombres adultos pertenecientes a la etnia Wounaan 
procedentes de diferentes resguardos del departamento del Chocó que hablan español, víctimas de desplazamiento forzado, residentes en el barrio "el tesoro" localidad de Ciudad Bolívar, con la aclaración de que estos últimos no son profesionales.

Como dijimos anteriormente, según Peces-Barba (1987) operador jurídico se refiere a "un genérico que identifica a todos los que con una habitualidad profesional, se dedican a actuar en el ámbito del derecho, sea como creadores, como intérpretes, como consultores o aplicadores del derecho..." (Pág. 448). Los operadores jurídicos participantes decidieron hacer parte del presente estudio de manera voluntaria, bajo consentimiento informado, de acuerdo con las normas éticas para la investigación con seres humanos (American Psychological Association; 2002, Ver anexo 3). Por consiguiente, el muestreo fue no probabilístico, toda vez que la muestra "en el proceso cualitativo, $[\ldots]$ es un grupo de personas, comunidades $[\ldots]$ etc., sobre el cual se habrán de recolectar los datos, sin que necesariamente sea representativo del universo o población que se estudia" (Hernández, Fernández \& Baptista; 2010, p. 394), puesto que antes que ser representativo del universo, la selección pone su énfasis en que sea representativo del problema a tratar.

La recolección de los datos se efectuó a través de las entrevistas semiestructuradas realizadas a los participantes de acuerdo con lo anteriormente descrito. A medida que se realizaron los análisis comparativos de los contenidos de las mismas, los hallazgos fueron emergiendo fundamentados en los datos recogidos. De esta manera, es factible analizar las representaciones sociales de algunos indígenas en situación de desplazamiento forzado y operadores jurídicos que laboraron en entidades gubernamentales y no gubernamentales, quienes por medio de la ejecución de prácticas asistenciales humanitarias, procuraron el acceso a la justicia de los 
mencionados grupos étnicos. Cabe señalar, que en la investigación cualitativa es común el uso del muestreo teórico que para efectos del presente trabajo tomó como referencia la teoría de las representaciones sociales propuesta por Moscovici (1961) y los complementos aportados por Hall, Foucault y Bordieu.

Para la aplicación de dicho muestreo se codificaron las entrevistas a medida que se realizaron hasta llegar a la saturación. La entrevista semiestructurada se aplicó de manera individual a doce participantes adultos, hombres y mujeres que cumplieron con las características antes señaladas.

\section{Técnica de recolección de información}

Se utilizó como técnica de recolección de información una entrevista semiestructurada (la transcripción de las entrevistas se anexan en el CD-ROM), que exploró las categorías preestablecidas: derecho de acceso a la justicia, desplazamiento forzado, víctima, implementación de las leyes, atención, asistencia y reparación de indígenas y derecho a la justicia (Ver anexo 1), la cual estuvo conformada por preguntas abiertas, profundas y flexibles de tipo: general, para ejemplificar, estructural y de contraste según el modelo propuesto por Grinnell, Williams y Unrau (2009); citado en Hernández, Fernández \& Baptista (2010, p. 419). "El propósito de las entrevistas es obtener respuestas sobre el tema, problema o tópico de interés en los términos, el lenguaje y la perspectiva del entrevistado" (Hernández y cols; 2010, p. 420). En esta se indagó acerca de las representaciones sociales, experiencias y hechos relacionados con el delito socio político del desplazamiento forzado y acceso a la justicia de indígenas en procesos de atención, asistencia y/o reparación. Con base en la temática señalada se construyeron cincuenta preguntas predeterminadas de guía, las cuales se fueron 
complementando a medida que transcurrieron las entrevistas, con el objeto de profundizar, ampliar la información y precisar los conceptos requeridos.

\section{Procedimiento}

Para la consecución de la muestra se recurrió al abordaje directo en la ciudad de Bogotá de doce participantes hombres y mujeres adultos. Luego de realizar la inmersión inicial para reconocer y observar el contexto, se procedió a la aplicación de la entrevista semiestructurada utilizando diversos espacios abiertos y cerrados ubicados en la ciudad de Bogotá. Esta se administró de forma individual con duración máximo de una hora, donde se informó a cada participante acerca del motivo del estudio y el uso posterior de los resultados obtenidos.

El procedimiento del presente trabajo de investigación se efectuó en tres fases:

Fase I: Diseño de la entrevista semiestructurada. Diseño de la entrevista semiestructurada Representaciones sociales de algunos indígenas en situación de desplazamiento forzado y operadores jurídicos que laboraron en instituciones gubernamentales y no gubernamentales de la capital, atendiendo los nombrados grupos étnicos, procurando su acceso a la justicia. Se tuvo en cuenta que la entrevista reuniera requisitos básicos de redacción, pertinencia y construcción apropiada de los reactivos de acuerdo con las categorías preestablecidas, en función de indagar acerca de las representaciones sociales de los operadores jurídicos e indígenas tratados en el presente estudio. "Las entrevistas semiestructuradas, se basan en una guía de preguntas y el entrevistador tiene la libertad de introducir preguntas adicionales para precisar conceptos u obtener mayor información sobre los temas deseados, es decir, no todas las preguntas están predeterminadas” (Hernández, Fernández y Baptista; 2010, p. 418) 
Fase II: Aplicación de la entrevista semiestructurada a los participantes. En esta fase, se aplicó la entrevista semiestructurada Representaciones sociales de algunos operadores jurídicos e indígenas en situación de desplazamiento forzado, acerca del acceso a la justicia estatal, a doce participantes que reunieron los criterios previamente establecidos de inclusión; cuatro operadores jurídicos hombres y mujeres adultos pertenecientes a varias ONG, cuatro operadores jurídicos hombres y mujeres adultos pertenecientes al Centro Dignificar de la Localidad de Suba y cuatro indígenas hombres adultos víctimas de desplazamiento forzado pertenecientes a la etnia Wounaan procedentes de diversos resguardos del departamento del Chocó, que en la actualidad perviven en la Localidad de Ciudad Bolívar, quienes bajo consentimiento informado decidieron participar en el presente estudio (ver anexo 3).

Fase III: Análisis de los datos. Luego de efectuar la transcripción de la información recogida, se realizó la codificación abierta, axial y selectiva de los datos, con el objeto de fragmentarlos, conceptualizarlos y categorizarlos. Empleando para ello, el programa sistematizado Atlas. Ti (Hernández, Fernández \& Baptista; 2010, p. 470)

Es de anotar, que a partir de la categoría central "Representaciones sociales de los operadores jurídicos e indígenas acerca del acceso a la justicia de los grupos étnicos" emergieron las siguientes categorías: derecho de acceso a la justicia, enfoque diferencial, atención a indígenas, victimización secundaria y vulneración de derecho humanos. 


\section{Resultados y discusión entre el marco conceptual y los hallazgos}

A continuación se muestran las categorías emergentes, partiendo de la categoría central "Representaciones sociales de operadores jurídicos e indígenas sobre el acceso a la justicia de los grupos étnicos", las cuales se analizarán en el siguiente orden: derecho de acceso a la justicia, enfoque diferencial, atención de indígenas, vulneración de derechos humanos y victimización secundaria.

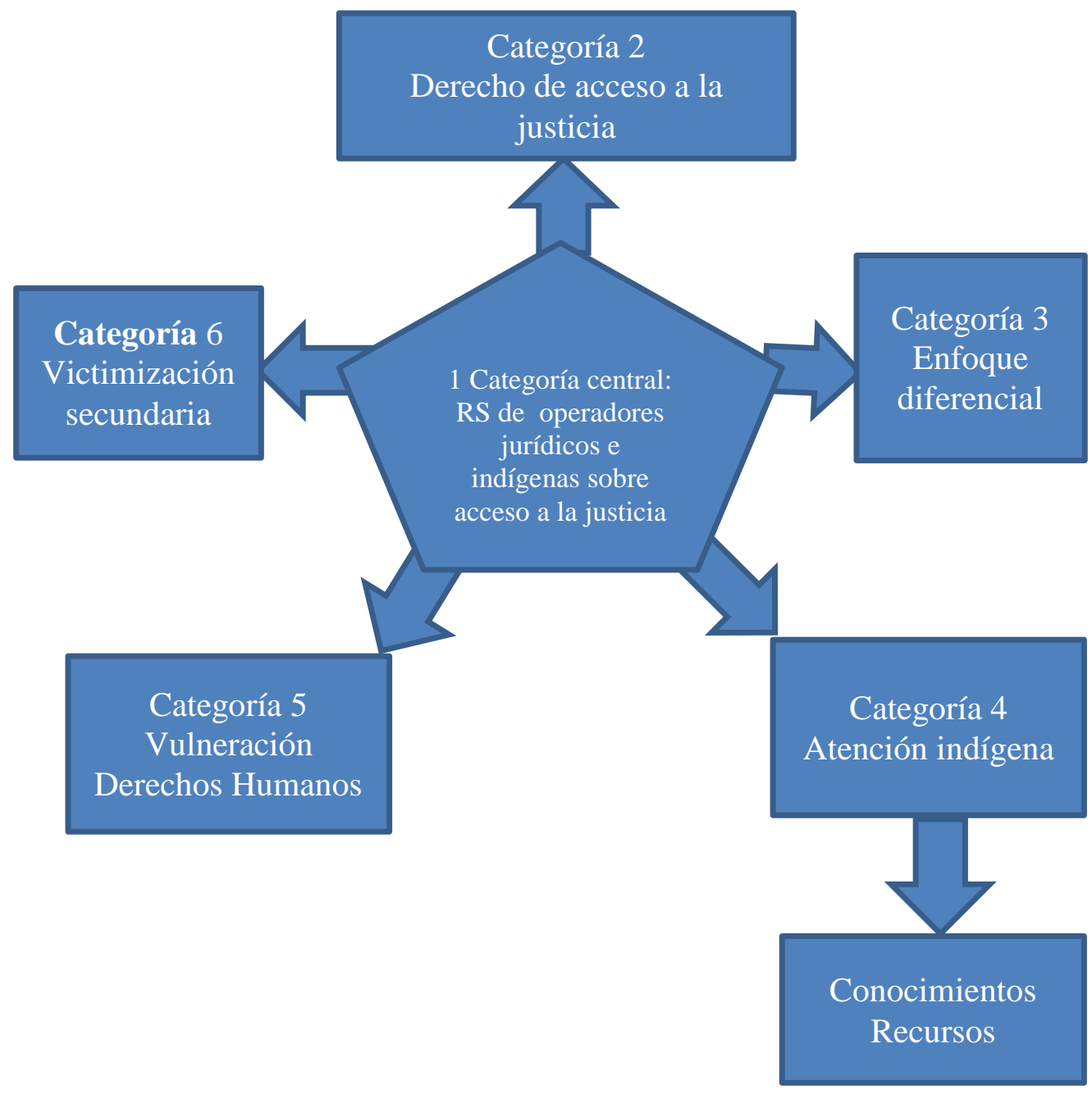

Figura 1. Categorías emergentes a partir de la categoría central "Representaciones sociales de operadores jurídicos e indígenas sobre el acceso a la justicia de los grupos étnicos"

Fuente: autor 
Después de realizadas las entrevistas y de procesada la información con el apoyo del programa sistematizado atlas ti, emergieron las categorías señaladas en la figura 1. Las cuales se analizan a partir de la categoría central "Representaciones sociales de operadores jurídicos e indígenas sobre acceso a la justicia de los grupos étnicos”, a saber: derecho de acceso a la justicia, enfoque diferencial, vulneración de los derechos humanos, victimización secundaria y atención a indígenas en situación de desplazamiento forzado.

\section{Representaciones sociales de operadores jurídicos e indígenas}

Las representaciones sociales, RS, son un "corpus" organizado de conocimientos y una de las actividades psíquicas gracias a las cuales los hombres hacen inteligible la realidad física y social, se integran en un grupo o en una relación cotidiana de intercambios, liberando los poderes de su imaginación (Moscovici, 1979, P. 17-18; citado en Mora, 2002, p.7). Para el análisis de la información se tuvieron en cuenta los elementos de las representaciones sociales nombrados por Moscovici; imágenes, informaciones, opiniones y actitudes.

Los operadores jurídicos opinan que la atención que se brinda a los indígenas en situación de desplazamiento forzado es relativamente buena. Informan que se han realizado acciones importantes en Bogotá y Medellín para atenderlos. Esto significa que los operadores reconocen la existencia de algunos aspectos que deben ser mejorados en cuanto a la atención y acceso a la justicia de los indígenas.

...Se ha hecho un trabajo importante en Bogotá y sé que Alcaldías también como las de Medellín, heee, tienen acciones importantes y específicas para indígenas y 
eso sobre todo en estas dos ciudades que tienen como atención fuerte, relativamente buena (S.C. Entrevista No. 1, abril 26 de 2013; 03:05 pm).

Los operadores carecen de información precisa acerca de los bienes que los indígenas se ven obligados a abandonar a causa del desplazamiento forzado. Esto significa que presentan déficits de conocimientos e información acerca del desplazamiento forzado: “...en realidad los bienes, no sé si sean bienes, ellos lo que sí han abandonado sobre todo, son tierras remotas en el país en las que hay difíciles condiciones de acceso..." (S.C. Entrevista No. 1, abril 26 de 2013; 03:05 pm).

Sin embargo, los indígenas Wounaan informan que al ser desplazados del Departamento del Chocó, se vieron obligados a abandonar sus pertenencias, presentándose la vulneración de sus derechos. Lo cual significa una grave afectación, ya que de acuerdo con su cosmovisión, estos relacionan territorio y cultura.

...yo tenía mi finquita de banano, papa china, ¿de pronto ha escuchado papa china?, la yuca, todos esos, a nosotros nos duele, porque heee no hay quién compre, incluso la casa tenemos también, todas mis lanchitas están allá, no hay quién compre y dejamos así abandonadamente sin dejar a quien recomendarse (T. Cabezón. Entrevista No. 6, Junio 8 de 2013; 12:20 pm).

Los operadores carecen de información acerca del Decreto Ley 4633 de 2011, el cual se enfoca específicamente en la atención, asistencia y reparación integral de los grupos indígenas: “...no conozco el Decreto tal vez, o tal vez sí, supongo que debe ser posterior a la Ley de Víctimas, pero no sé”... (S.M. Entrevista No. 3, mayo 14 de 2013; 2:40 pm). En este orden de ideas, el desconocimiento de las leyes que regulan los derechos de los indígenas, significa falta de idoneidad para desempeñar el cargo y desinterés por mantenerse actualizado en cuanto a las normas vigentes. Factores que 
influyen negativamente en la calidad de la atención ofrecida a los indígenas y su acceso a la justicia.

Los indígenas de la etnia Wounaan, informan sobre la vulneración de los derechos humanos que se viene presentando en el Departamento del Chocó, a causa del conflicto armado interno: “.... en Chocó es muy complicaísimo, ¿ya? la gente que no sabe llega allá, eso lo cogen no sé, lo torturan, lo que ellos hacen. ¿ya? Eso allá es muy complicaísimo (D.C. Mercasa. Entrevista No. 8, junio 8 de 2013; 2:35 pm)

En tal sentido, se demuestra la incapacidad del Estado para garantizar la protección de los indígenas en sus territorios y resguardos de origen. Así como el estado de indefensión y de desamparo en que se encuentran, viéndose sometidos a toda clase de atropellos por parte de los diferentes grupos armados que detentan el poder en las zonas alejadas del país.

Igualmente, los indígenas afectados se encuentran desinformados y manifiestan no recibir apoyo del Estado. Indican que los operadores no les ofrecen información precisa acerca de las rutas de atención ni de los derechos que les asisten como víctimas del desplazamiento forzado, lo que se convierte en revictimización secundaria.

“...todavía no les vistos nada de colaboración, en la parte de apoyo de arriendo tampoco no me han dado, porque como le he dicho que todavía, me han, llevo apenas diez días, me faltan para cumplir los noventa días y todavía no tengo la claridad todavía, no sé después de cumplir eso que va a pasar a mí, ¿sí? Pero actualmente no he recibido ningún apoyo del desplazamiento" (T. Cabezón. Entrevista No. 6, Junio 8 de 2013; 12:20 pm).

Lo anterior, significa que los procesos de atención, asistencia y reparación que brinda el Estado son insuficientes y dilatorios. Los indígenas permanecen en situación de 
incertidumbre e inestabilidad, desorientados acerca de los trámites, tiempos y las instituciones donde deben acudir a fin de solicitar la asistencia a la que tienen derecho, por hacer parte de grupos étnicos en situación de desplazamiento forzado. De igual modo, son vulnerables, toda vez que se encuentran en una ciudad desconocida, en un contexto diferente, no poseen el manejo adecuado del idioma, carecen de todo tipo de recursos para subsistir, sin medios de transporte para desplazarse, por tanto, se encuentran en situaciones adversas que son difíciles de enfrentar sin la ayuda estatal.

La imagen que poseen los indígenas es que el apoyo que brinda el Gobierno Nacional es insuficiente: “...yo veo a mi tío (gobernador del cabildo wounaan) no le están dando muchas cosas, aquí lo que conseguimos como hay muchos, a nosotros es compartir, si otro consiguió pues es para compartir" (T. Cabezón. Entrevista No. 6, Junio 8 de 2013; 12:20 pm).

Por tal motivo, los indígenas sobreviven a través de los recursos que perciben por la elaboración y posterior venta de artesanías. Esto significa que el Estado se queda corto para suplir las necesidades básicas de los grupos étnicos. Igualmente, significa que el sistema establecido por el gobierno para la atención, asistencia y reparación integral de los indígenas, presenta múltiples fallas de cobertura.

Los indígenas se sienten desatendidos, rechazados e incomprendidos debido a las actitudes de incredulidad y desinterés que muestran algunos operadores jurídicos durante la atención a los mismos, generándoles revictimización secundaria.

...uno se va al "Dignificar", ellos casi no atienden a uno, le dejan como rechazado, a veces no creen de uno, uno lo explica bien: yo vengo desplazado, vengo de tal parte pero a veces ellos no, no creen ¿ya? No sé, es por mal 
entendimiento, o por, por no atender (D.C. Mercasa. Entrevista No. 8, junio 8 de $2013 ; 2: 35 \mathrm{pm})$

Por medio de este relato, se puede demostrar la discriminación que ejercen algunos operadores jurídicos hacia los indígenas, significa que a estos los representan como personas inferiores. Los operadores al asumir actitudes de rechazo y exclusión empeoran la precaria situación de los afectados, revictimizándolos.

Más aún, la imagen que poseen los operadores jurídicos consiste en que los indígenas tendrían que permanecer en sus territorios y no en la ciudad, desconociendo las consecuencias del conflicto armado interno, enseñando una actitud de incredulidad frente el fenómeno del desplazamiento.

...yo cuando veo un desplazamiento de indígenas en Bogotá y digo pero ¿qué pasó? o sea, ¿qué hizo que esos indígenas llegaran hasta acá? es una locura, porque la mayoría de los pueblos indígenas que sufren desplazamiento forzado están en zonas muy retiradas de Bogotá... (E.J. Entrevista No. 11, septiembre 5 de 2013; 07:00 pm).

Los indígenas Wounaan, poseen la imagen de que es difícil acceder a la justicia estatal, debido a la cantidad de trámites y documentos que les exigen para ello. Lo cual significa que las víctimas tienen poca credibilidad en la eficacia de las instituciones y los procesos que estas adelantan. De igual modo, los indígenas representan a los operadores jurídicos como sujetos que se resisten a prestarles la ayuda requerida.

...vemos muy difícil por lo que veo, que hasta que no tengamos los papeles bien claramente en la mano, los censos, la fecha de nacimiento de los niños, bueno, cuando se habla de los censos se habla es la edad, qué día nació, de dónde es, qué lugar vive, qué... bueno todas las direcciones ellos nos exigen, hasta que 
nosotros no presentamos eso ellos no lo creen (T. Cabezón. Entrevista No. 6, Junio 8 de $2013 ; 12: 20$ pm).

De esta manera, los indígenas tienen la imagen de que el Estado no les ofrece respuestas concretas frente a los problemas originados por el desplazamiento forzado: “...muchas reuniones, y usted diga qué es lo que le pasa, cuénteme su historia y ya. Respuestas concretas a esos problemas yo no los veo" (D.V. Entrevista No. 12, septiembre 6 de 2013; 3:00 pm).

Peor aún, es que los indígenas opinen que los operadores jurídicos sólo se limitan a devengar un sueldo pero no los apoyan como es debido. Significa que los indígenas se encuentran inconformes con la atención que ofrecen los operadores jurídicos.

...ellos piensan más que todo en su dinero, no son de capaz de ayudarle al otro, por lo menos que ahorita nosotros estamos, nosotros estamos buscando que nos apoyen, nos apoyen, apoyen como tal, estamos diciendo, muchas gentes llegan, salen con la mentira, dicen que los vamos a ayudar que sí les vamos a colaborar con tal cosa, pero a la hora de verdad no (T. Cabezón. Entrevista No. 6, Junio 8 de $2013 ; 12: 20 \mathrm{pm})$.

Algunos operadores jurídicos opinan que los indígenas en situación de desplazamiento forzado, permanecen en la ciudad porque las condiciones de vida son funcionales para ellos.

...indígenas que se desprenden de sus grupos y se quedan en Bogotá y familias que se quedan en Bogotá deambulando, también lo hacen porque empiezan a ser muy funcionales las condiciones que esta ciudad empieza a darles, a pesar de que 
uno los ve como en la calle pidiendo y no sé qué. Al parecer, eso se va volviendo un estilo de vida (E.J. Entrevista No. 11, septiembre 5 de 2013; 07:00 pm).

También, los operadores jurídicos opinan que el Estado carece de una estructura real de respuesta para la aplicación del enfoque diferencial.

...A pesar de que la ley es toda sofisticada en eso, en la vida práctica, la estructura real de respuesta del Estado no es una estructura diseñada para atender con un enfoque diferencial a nadie. La verdad, sinceramente uno tiene que decir que los indígenas o los afrocolombianos se tienen que acomodar a lo que hay la mayoría de las veces (E.J. Entrevista No. 11, septiembre 5 de 2013; 07:00 pm).

Estos operadores opinan, que existen barreras culturales para entender el enfoque diferencial: “...yo creo que en Colombia tenemos unas barreras culturales entre nosotros mismos, raciales, y de distintos órdenes que nos dificulta mucho entender lo que significa realmente un enfoque diferencial" (E.J. Entrevista No. 11, septiembre 5 de 2013; 07:00 pm).

De acuerdo con las opiniones expresadas por los indígenas, se observa que desconocen o no tienen claro el concepto de justicia occidental: “...sobre de la justicia, creo que si hay, no sé pues yo no sé bien, bien la verdad no sé bien, para que yo le digo, lo que yo no sé" (T. Cabezón. Entrevista No. 6, Junio 8 de 2013; 12:20 pm). En tal sentido, a los indígenas sólo les interesa que les restituyan sus derechos.

El hallazgo fundamental de la investigación, nos muestra que las categorías emergentes en torno a las representaciones sociales del acceso a la justicia de la población desplazada indígena, se encuentran relacionadas y articuladas de manera consecutiva, de tal forma que una es causa y consecuencia de la otra: el derecho de acceso a la justicia se encuentra relacionado con la atención ofrecida por los operadores 
jurídicos a los indígenas víctimas de desplazamiento forzado, la cual está mediada por el cumplimiento de las funciones, los recursos logísticos que poseen y la información que brindan de acuerdo con los conocimientos que poseen acerca de las rutas de atención, para que los indígenas acudan a las diversas entidades en busca de asistencia jurídica, salud, educación, vivienda, alimentación etc., que les garantice un mínimo vital durante su estadía en la ciudad. De acuerdo con los relatos suministrados a través de las entrevistas, los miembros de la etnia Wounaan en situación de desplazamiento forzado, señalan que no son escuchados. "...Yo digo que los funcionarios escucharan todo lo que nosotros realmente sintiéramos, creo que algunas cosas ya estarían resueltos para lo que es de beneficio para la gente víctima como desplazados" (A.C. Piras. Entrevista No.5, junio 8 de 2013; 11:10 am), debido a que ciertos operadores jurídicos tanto gubernamentales como no gubernamentales desconocen el derecho de acceso a la justicia de los indígenas o no creen que sean víctimas de desplazamiento forzado a causa de los grupos armados sino que son desplazados económicos. “...los criterios siempre son como filtrar a ver sino son desplazados económicos como los llaman o ese tipo de cosas” (E.J. Entrevista No. 11, septiembre 5 de 2013; 07:00 pm), mostrando con ello actitudes de incredulidad y de rechazo que empeora el vínculo empático necesario para la atención y apoyo al desplazado, y en consecuencia agravan las condiciones físicas y psicológicas de los indígenas.

Igualmente, se presentan trabas debido a que la Ley 1448 de 2011 en el artículo tercero establece como víctimas únicamente a quienes hayan sufrido daños con ocasión del conflicto armado interno, señalando como grupos armados a los guerrilleros y autodefensas, que según el gobierno, estas últimas se desmovilizaron. En este orden de ideas, estructuras criminales armadas como los denominados urabeños, paisas, águilas, 
rastrojos etc., son consideradas bandas criminales emergentes, BACRIM, conforme lo referido en la Sentencia C-253 A /2012. De tal manera, se obstruye el acceso a la justicia de los indígenas víctimas de desplazamiento forzado a mano de estos grupos, toda vez que al ser desplazados por las señaladas bandas organizadas deben interponer recursos como el derecho de petición y acciones de tutela a fin de que sean considerados víctimas del desplazamiento forzado, invocando la Sentencia 052/2012 sobre definición de víctimas entre otras.

Más aún, encontramos en el nivel procedimental, que entre los documentos solicitados a los miembros de los grupos indígenas en situación de desplazamiento forzado, se encuentra la libreta militar: "llevamos un año sin trabajo de empleo porque para nosotros buscar un trabajo comienzan a pedir la libreta militar y ninguno de nosotros no tenemos libreta militar, entonces por eso no hemos podido conseguir el empleo del trabajo" (A.C. Piras. Entrevista No.5, junio 8 de 2013; 11:10 am). En tal sentido, el artículo 27 de la Ley 48 de 1993 los exime de hacerlo, desconociendo la condición diferencial étnica, su jurisdicción especial por lo que son representados como cualquier otro poblador colombiano, "blanco-mestizo".

De igual manera, para la restitución de tierras les exigen los títulos correspondientes a fin de demostrar que son los legítimos dueños del territorio que ocupaban, lo que es en la mayoría de veces imposible puesto que no todos los resguardos se encuentran legalizados ante la ley, a pesar de que durante varios siglos han convivido en ellos siendo los genuinos tenedores desde épocas ancestrales.

Estamos en un país en el que nos gobiernan las leyes primordialmente, una comunidad indígena no tiene una propiedad formal sobre la tierra, sino es una propiedad fáctica ancestral que pues está anterior a todas las leyes que se han 
inventado acá, (tos) digamos que siempre se les va a imponer algún tipo de requisito por más mínimo que sea se les va a imponer a las personas indígenas, ya sea que tienen, sino tienen certificado de tradición tienen que generar que se les haga un certificado, o si no hay un certificado y no se puede conseguir, por lo menos tiene que llegar una sentencia de un juzgado ordinario civil que diga que esa tierra si es de ellos...(S.M. Entrevista No. 3, mayo 14 de 2013; 2:40 pm).

Lo cual demuestra la tensión existente entre el paradigma del derecho positivo y el derecho natural, entre el enfoque romano-occidental y el de la ley o normatividad étnico-andina que se ha basado en la memoria ancestral y en la palabra como pacto, no en el documento escrito como contrato. Esta exigencia está fundamentada en una representación del indígena como sujeto occidentalizado, dicho de otra forma, la ley de reparación sigue operando como un instrumento colonial de la cultura y la subjetividad indígena, como si su voz dijera: compórtate bajo las prácticas y costumbres romanooccidentales para poder ser reconocido en tus derechos, lo que de paso tiene un contenido de dominación y poder radical: deja de ser tú, sé como yo para poder reconocerte el derecho.

En este mismo sentido, también se les exige a los indígenas un censo pormenorizado de los integrantes de la etnia a la que pertenecen.

A nosotros nos exigen de primer punto es el, los censos, los censos de todos de nosotros, para el apoyo, bueno para cualquier apoyo siempre nos exigen es eso, y escritas las cartas, bien escritas las cartas, hecho con mano o bien puede ser en sistemas ¿sí? Hay que entregar, y tenemos que tener una cita también para poder entregar ese día, eso es lo que yo veo aquí una parte nosotros vemos muy difícil, por lo que veo que hasta que no tengamos los papeles bien claramente en 
la mano, los censos, la fecha de nacimiento de los niños, bueno, cuando se habla de los censos se habla es la edad, que día nació, de dónde es, qué lugar vive, qué, bueno todas las direcciones ellos nos exigen, hasta que nosotros no presentamos eso, ellos no lo creen...(T. Cabezón. Entrevista No. 6, Junio 8 de 2013; 12:20 pm). Se les exige que piensen como sujetos modernos, gobernados por la gestión de la población, por el conteo estadístico del pueblo.

Según lo indicado por los operadores jurídicos, los registros de las comunidades indígenas se encuentran "desactualizados", ya que sólo se han caracterizado aproximadamente tres etnias indígenas en el país, los Awa, Embera Chamí y los Nasa.

...El proceso de caracterización dentro de los territorios colectivos no se ha logrado, sólo se ha logrado en dos o tres comunidades Awa, la que desplazaron ahorita los Embera Chamí... y algunos pueblos Nasa no más, caracterizaciones es como determinar qué pasó, pero las medidas de atención diferencial en salud, en educación, y ni hablar sobre la reparación a territorios colectivos... (D.F.L. Entrevista No. 9, julio 17 de 2013; 2:25 pm).

Dejando ver en ello, tanto un choque cultural como una modalidad de resistencia de las comunidades a ser subsumidas por la lógica administrativa de la población, de la tierra y de la vida.

De otro lado, para poder acceder a la justicia estatal se requiere interponer la respectiva denuncia ante las autoridades competentes, lo que generalmente a las víctimas indígenas les produce temor a causa de las amenazas que les profieren los integrantes de los actores armados, teniendo en cuenta que algunos de sus familiares se encuentran aún en los territorios confinados en lugares apartados del país con restricciones de movilidad para cazar, pescar y realizar sus prácticas habituales. 
Para acceder a este tipo de servicios o de derechos, se les exige generalmente, interponer denuncias ante la justicia ordinaria, la justicia occidental, que es la que manejamos nosotros en estos centros en estas oficinas y pues digamos que en la mayoría de los casos, sino en todos digamos, que no siempre se tiene en cuenta la concepción de, de la, de estas comunidades, de este tipo de personas (S.M. Entrevista No. 3, mayo 14 de 2013; 2:40 pm)

También sucede que la mayoría de las víctimas emplean sus propios dialectos nativos, y a pesar de que el Decreto Ley 4633 de 2011 ordena disponer de intérpretes de dichas lenguas, conforme lo referido por los operadores gubernamentales si en la capital cuentan con muy pocos traductores en el resto del país probablemente sean inexistentes. Algunos traductores están ubicados en la Alta Consejería de la Alcaldía Mayor de Bogotá y únicamente para la atención de los indígenas de los grupos Emberas, desconociendo que en Colombia existen alrededor de 102 grupos indígenas de los cuales varios hacen presencia en la capital del país. Razón por la cual, en el momento que las víctimas de desplazamiento forzado acuden ante el ministerio público para rendir la declaración de los hechos, esta versión no sólo no es traducida sino que queda tergiversada debido a las barreras del lenguaje, impidiendo el adecuado acceso a la justicia. Esta situación es reflejo no tanto de la desatención del sistema para con el indígena como de una práctica etnocéntrica en la que el Estado y sus funcionarios nunca se ocuparon de tener suficientes antropólogos y lingüistas formados para mediar, traducir y sobre todo, escuchar a las poblaciones indígenas vulnerables y vulneradas.

Igualmente, se pudo observar que varios de los operadores jurídicos gubernamentales que laboran en el Centro Dignificar de la Localidad de Suba, se ven obligados a proporcionar sus propios equipos de cómputo para atender a las víctimas, 
no todos cuentan con servicio de internet para consultar las bases actualizadas de datos de las víctimas del desplazamiento forzado o realizar los enlaces con las instituciones como el ICBF, Fiscalía General de la Nación, Ministerio Público y fuerza pública.

Algunos operadores gubernamentales afirman: "debería nutrirse más, falta personal, faltan psicólogos, trabajadores sociales porque somos dos equipos, pero falta más personal y talento humano" (J.D.Q. Entrevista No. 4, mayo 15 de 2013;12:15 pm), no cuentan con el recurso humano suficiente para la atención de las víctimas de desplazamiento forzado, toda vez que se requieren más profesionales expertos en el conocimiento de la cultura de los diferentes grupos indígenas tales como antropólogos, psicopedagogos y trabajadoras sociales. En cuanto a los integrantes de grupos indígenas víctimas de desplazamiento forzado manifiestan: “[...] nosotros no tenemos dinero para estar recorriendo pallá y pacá y eso es andar así a pie, no ve que toca es andar a carro, y pa andar, para pagar esos pasajes dónde conseguimos, no tenemos cómo pagar" (T. Cabezón. Entrevista No. 6, Junio 8 de 2013; 12:20 pm)

Los operadores jurídicos no gubernamentales entrevistados señalan que los operadores gubernamentales cuentan con mayores recursos logísticos para trasladarse a los territorios donde se presentan los desplazamientos forzados de los indígenas tales como viáticos, medios de transporte, estadía y alimentación; mientras que sólo algunas ONG sobre todo de carácter internacional poseen dichas facilidades, incluso cuentan con medidas de seguridad especiales proporcionadas por la ONU tales como seguimiento satelital de las operaciones en terreno. En este sentido, la misma intervención y apoyo a las comunidades indígenas refleja la disparidad entre el capital económico y simbólico existente entre operadores internacionales, gubernamentales y locales. 
Pero más grave aún es poder observar que los sistemas de representación y clasificación social sugieren pensar que para algunos operadores jurídicos existen unos indígenas que son mejores que otros, que hay unas víctimas étnicas más dignas de atención que otras. Los miembros de los grupos indígenas en situación de desplazamiento forzado afirman que existen privilegios en la atención, asistencia y reparación de algunas etnias. Por ejemplo: “[...] algunas comunidades o algunos territorios que hayan desplazados tienen más apoyo, por lo menos han tenido más apoyo son los Embera, los Katío, los Kankuamos y otras etnias que han tenido más apoyo del Estado" (A.C.Piras. Entrevista No. 5, junio 8 de 2013; 11: 10 am).

También, aseveran que ciertas etnias poseen representantes o compañeros que laboran en diferentes entidades gubernamentales y no gubernamentales los cuales les prestan apoyo y les privilegian; “[...] nosotros queremos un compañero que está allá o en un oficina para que atiendan bien ¿sí? como nosotros no tenemos un compañero hay veces nos atienden, vengan mañana o pal otro como no tenemos representante en la oficina" (H.O. Ismari. Entrevista No. 7, junio 8 de 2013; 11:30 pm). Es así como otros grupos étnicos poseen personas que los acompañan en las gestiones para la asignación de vivienda, salud y educación, líderes que los representan en las mesas de concertación con el gobierno de acuerdo con lo descrito en el convenio OIT (Organización Internacional del Trabajo) No. 169 de 1991, donde el gobierno debe consultar a los diferentes grupos indígenas acerca de las medidas legislativas o administrativas que afecten su cultura y calidad de vida. Por lo anterior, se hace necesario un trato equitativo en el que los indígenas cuenten con personas que conozcan las rutas de atención y se encuentren dispuestas a servirles, más allá del etnocentrismo o de las disputas por los escasos recursos entre etnias, de enlace ante las diferentes entidades 
para acelerar los correspondientes procesos de restitución de sus derechos, tarea que puede ser cumplida por los profesionales de las ciencias sociales, pero en especial por los profesionales en psicología jurídica.

Respecto a la categoría del enfoque diferencial contemplado en el artículo séptimo de la Carta Magna y en el Título III del Decreto Ley 4633 de 2011, tanto los indígenas como los operadores gubernamentales y no gubernamentales entrevistados manifestaron que se incumple en aspectos de alimentación debido a que les son suministrados enlatados que les produce trastornos digestivos, reciben el mismo trato que otras personas afectadas por el desplazamiento.

Debido a que en sus territorios estaban acostumbrados a consumir carne fresca, producto de la pesca y de la caza en abundantes proporciones, como desplazados deben renunciar a sus prácticas alimentarias.

En tal sentido, el Distrito les suministra tres mercados básicos cada tres meses, donde cada uno debe alcanzar para un mes, pero este es precario y es consumido aproximadamente en ocho días. Los indígenas explican que son insuficientes porque generalmente ellos conviven en familias numerosas, por su cosmovisión colectiva comparten sus pertenencias con todos los miembros integrantes del cabildo Wounaan. En tal sentido enuncian: “[...] yo veo a mi tío Américo (gobernador cabildo wounaan) no le están dando muchas cosas, aquí lo que conseguimos como hay muchos, a nosotros es compartir si otro consiguió pues es para compartir, por ejemplo: en mercados..." (T. cabezón. Entrevista No. 6, junio 8 de 2013; 12:20 pm).

Las raciones son pequeñas frente a lo que acostumbraban consumir en sus territorios, motivo por el cual estos suministros son insuficientes y consumidos rápidamente. Al respecto los operadores manifiestan: "[...] lo que nosotros le 
entregamos para 30 días ellos se lo comen en una semana, y para nosotros un grupo familiar está constituido por cinco personas, para ellos un grupo familiar puede estar constituido por diez personas" (D.F.L. Entrevista No. 9, julio 17 de 2013; 2:25 pm). Además, los operadores no gubernamentales afirman que en los territorios alejados les suministran bultos de fríjoles, siendo inadecuado porque no cuentan con los accesorios para la cocción de los mismos (E.J. Entrevista No. 11, septiembre 5 de 2013; 7: 0 pm).

Otro aspecto a mejorar en el trato y enfoque diferencial es el concerniente al vestuario, confirman que el Estado no les proporciona los elementos necesarios para elaborar los trajes emblemáticos de cada etnia. Usualmente, los indígenas se muestran muy conservadores y orgullosos de sus costumbres ancestrales, manifiestan su inconformidad por tener que usar zapatos, pantalones y chaquetas para protegerse del clima frío de la capital (T. cabezón. Entrevista No. 6, junio 8 de 2013; 12:20 pm) recibiendo el mismo trato que los mestizos, ciudadanos y campesinos, mostrando falencias acerca de la adecuada implementación del enfoque diferencial.

También, los indígenas wounaan manifiestan su descontento por tener que emplear el idioma español en la ciudad, refiriéndose así: “[...] no hablamos bien claramente en español, siempre es, el español es prestado para nosotros es prestado o (ríe) alquilado" (T. cabezón. Entrevista No. 6, junio 8 de 2013; 12:20 pm), estos se ven obligados a usarlo ya que en las entidades estatales no cuentan con suficientes intérpretes. Para los wounaan es muy importante que los hijos conserven sus tradiciones culturales (bailes, lengua, ritos etc.) pero indican que los niños asisten a colegios y jardines del Distrito Capital donde adquieren malas costumbres como el hurto de los útiles escolares y la violencia existente entre sus compañeros de estudio. O sea, que al desconocer sus diferencias y forzarlos a dejar su lengua y sus costumbres, siguen siendo 
objeto de una colonialidad contemporánea, que arrasa sus tradiciones, su identidad, su modo de ser y les obliga a comportarse del modo en que el contexto los forma, les da forma, los modela.

Los operadores jurídicos entrevistados afirmaron que varios indígenas en situación de desplazamiento forzado se encuentran temporalmente ubicados en albergues totalmente hacinados, permaneciendo encerrados cuando estos conviven en espacios abiertos, por tal motivo algunos prefieren salir a las calles a mendigar. En estos albergues deben ceñirse a determinados manuales de convivencia a fin de evitar conflictos entre las diferentes etnias y otros grupos étnicos desplazados, razón por la cual algunas víctimas optan por salir de estos sitios para solicitar ayuda económica y alimentaria en las calles de la ciudad. Esta práctica de hacinarlos y ubicarlos a todos en un mismo lugar implica que el operador jurídico como agente del Estado se representa a los indígenas como una unidad generalizada, como un indígena indiferenciado, desconociendo las diferencias entre los más de cien grupos étnicos existentes en el territorio y de paso negando los conflictos y disputas ancestrales entre los mismos grupos.

Otro aspecto a tratar es el tema de salud que es manejado a través de la red de hospitales públicos de la ciudad, sobre esto han referido los indígenas que la atención es dilatoria, y además no son atendidos o acompañados por sus médicos tradicionales. “[...] porque como cultura indígena nuestro territorio tenía nuestro médico tradicional, y entre los médicos tradicionales pues la atención no es de tanto tiempo" (A.C. Piras. Entrevista No. 5, junio 8 de 2013; 11: 10 am). Nuevamente quedan al descubierto fallas en la atención que conducen a la victimización de los desplazados por cuanto los 
afectados sufren deterioro de su salud física y mental, daños que pueden ser evaluados a través de peritajes psicosociales o psicojurídicos efectuados por el psicólogo jurídico.

Igualmente, frente al fracaso de la existencia y uso del enfoque diferencial los operadores gubernamentales ratifican que la capacitación recibida no se encuentra enfocada a atender a los grupos indígenas sino a todas las víctimas de desplazamiento forzado en general. Por ello declaran que: “[...] acceso a capacitaciones tal vez, en lo que tiene que ver con atención psicosocial pero así no, indígenas específicamente indígenas no”. Cabe señalar, que la atención ofrecida a los grupos de indígenas carece de enfoque diferencial en cuanto a su cosmovisión, toda vez que para ello requieren expertos en culturas ancestrales que los “Centros Dignificar" de la capital ni el resto del país poseen o psicólogos jurídicos con capacidad de observar las particularidades de la identidad individual y colectiva de los indígenas ante la justicia occidental. En la medida que la identidad colectiva es negada, no reconocida, también su identidad psicológica es obstruida. Y es aquí donde creemos que el psicólogo jurídico puede articular su intervención.

Para que los operadores jurídicos puedan brindar una adecuada atención a los grupos de indígenas en situación de desplazamiento forzado, es necesario que cumplan con las funciones establecidas en los protocolos, contar con los recursos (logísticos, económicos, humanos etc.) y poseer los conocimientos necesarios que faciliten un desempeño adecuado en los respectivos cargos. En tal sentido, se evidencian fallas en cuanto a la representación, el conocimiento y aplicación de los protocolos de atención, los cuales se encuentran diseñados para atender a todos los grupos étnicos como si fueran campesinos o mestizos en general. De igual modo, observamos que varios operadores jurídicos entrevistados desconocen ciertas leyes entre ellas el Decreto Ley 
4633 de 2011 que se enfoca específicamente a la atención, asistencia, reparación integral y restitución de los territorios de los grupos indígenas en situación de desplazamiento forzado. Al respecto un operador expresó: “...no me acuerdo de esa, busquemos, espérate la busco por google ¿te parece?” (J.D. Entrevista No. 4, mayo 15 de 2013; 22:15 pm).

Al encontrarnos en un país donde continuamente se expiden leyes nuevas, es menester que los operadores se mantengan actualizados en el ámbito legal, recibiendo asesoría y capacitación de profesionales en derecho y psicología jurídica. También, se desconoce la cantidad exacta de indígenas víctimas de desplazamiento forzado y de las diferentes etnias existentes en el país. Según lo manifestado por los indígenas Wounaan, algunos operadores jurídicos gubernamentales no tramitan los documentos sino que ocasionalmente los rompen o archivan, desconocen la cosmovisión de los pueblos indígenas y los diferentes tipos de desplazamientos existentes (colectivo, individual, forzado y voluntario).

...Llenamos ese formato $y$ fuimos a entregarlo a un funcionario, yo personalmente se lo entregué, le dije: mire este documento me puede entregar a tal lugar. Pero que pasa después, otro compañero se fue a pedir a ver si habían entregado a la otra funcionaria, pero a pesar que a mí me dio fue un dolor, cuando él me dijo: mire cuando yo fui a recoger me rompieron fue los papeles (E.J. Entrevista No. 11, septiembre 5 de 2013; 7: 00 pm).

Ante algunos hechos anteriormente señalados, se observa la vulneración de los derechos humanos de los integrantes de los grupos indígenas víctimas de desplazamiento forzado, como el derecho fundamental a la vida. Toda vez, que los indígenas Wounaan y los operadores jurídicos confirman la ejecución de asesinatos de varios indígenas 
durante el desplazamiento y la ocurrencia de masacres emblemáticas, entre ellas la ejecutada en Bahía Portete 2004, en el departamento de la Guajira donde los grupos paramilitares ultimaron a doce indígenas de la tribu Wayuu y desplazaron varios centenares de los mismos hacia Venezuela.

En el mismo sentido, refiere un operador jurídico que durante el cumplimiento del "Plan patriota" desarrollado en la década del año 2000, en el medio Atrato chocoano, la fuerza pública accedió a los resguardos indígenas hasta los sitios donde efectuaban los rituales sagrados, dejando despojos mortales sin sepultar en los territorios, lo que causó el suicido de varios indígenas porque consideraban que la tierra resultaba enferma. "[...] Ellos empezaron como a tener unos desordenes como muy complejos en su vida emocional y en su vida espiritual y empezaron a suicidarse, se llegaron a suicidar más de veinte personas en esa comunidad en menos de un año" (E.J. Entrevista No. 11, septiembre 5 de 2013; 7: 00 pm).

De idéntica forma, se vulnera el derecho a la vida y habitación digna, debido a que no cuentan con vivienda propia, pasaron de su sentido de pertenencia ancestral a habitar en casas arrendadas donde permanecen hacinados, presentando filtraciones de agua que les ocasiona afecciones respiratorias y de las que pueden ser desalojados en cualquier momento.

Los indígenas confirman que se encuentran desempleados, derivan su sustento diario a través de la elaboración de artesanías, carecen de paz y tranquilidad por lo que solicitan que les restituyan y los dejen tranquilos en sus territorios. "[...] yo no fuera desplazado yo estaba tranquilo en mi casa, en mi tierra cultivando con mis niños y no estaba sufriendo de este frío de los niños" (H.O. Ismari. Entrevista No. 7, junio 8 de 2013; 11:30 pm). 
Igualmente, testimonian que los actores armados violan a las mujeres en los resguardos ubicados en el departamento del Chocó, otros tantos han sido víctimas de las minas antipersonales instaladas en sus territorios. Es de anotar, que mediante la ejecución de estos delitos se incrementa el exterminio y la extinción de las etnias indígenas colombianas, lo que significa la pérdida de la vida, de la identidad y de la diversidad cultural. Es así, como la Comisión Interamericana de Derechos Humanos ha proferido medidas cautelares para la protección de algunas etnias indígenas que se encuentran en peligro de desaparecer como los Nukak, los Kankuamos y los Wiwas.

Los operadores jurídicos señalan que especialmente los niños indígenas son explotados laboralmente en la capital por personas inescrupulosas que los obligan a mendigar en diferentes sitios de la ciudad. "[...] se han configurado unas dinámicas y unas estructuras directivas que también los explotan... sí, hay personas inescrupulosas que están utilizando esta situación para enriquecerse, y utilizan generalmente los niños para ese fin” (D.F.L. Entrevista No. 9, julio 17 de 2013; 2:25 pm). De este modo, el indígena es representado como un esclavo, como un ser de poca valía, su condición dignificada es su relación con su territorio es degradada y humillada dentro del mercado de los desechos de la economía: la limosna. Cabe señalar, que los niños y mujeres indígenas son más vulnerables entre otras razones porque conforme lo declarado por un integrante de la comunidad Wounaan los hombres suelen hablar mejor el idioma español, mientras que las mujeres se limitan a escucharlo. "[...] mire los wounaan, los hombres hablan bien los españoles, también lo poquito las mujeres que casi no hablan, pero entienden, entienden pero para hablar no" (H.O. Ismari. Entrevista No. 7, junio 8 de 2013; 11:30 pm). Lo cual deja entrever la reproducción en la ciudad de las vulnerabilidades de género al interior de las etnias. 
La justicia es muy blanda o premia a los...la justicia premia a los malos ¿sí? Es decir usted...imagínese sale de reparación a víctimas, se crean instrumentos, pero esos que cometen esos delitos se entran en un proceso de negociación con el gobierno y se perdona todo (D.V. Entrevista No. 12, sept. 6 de 2013; 3:00 pm).

Se vulnera el derecho a la justicia ya que relatan algunos operadores jurídicos que el Estado premia a los infractores de la ley como guerrilleros y paramilitares, las condenas son cortas y laxas, los organismos del Estado no investigan lo suficiente para dar con los responsables del delito de desplazamiento forzado hacia los grupos indígenas, no hay justicia ni paz, ni verdad, ni reparación integral porque, como dicen ellos, no ven ninguna persona indígena que haya conseguido alcanzar estos derechos señalados por las leyes estatales, aduciendo que se convierten sólo en promesas. “[...] por eso ¿Cuál es la reparación integral? deme un ejemplo, ¿Cuál ha sido reparado integralmente? para ver si ese modelo me sirve (ríe)" (D.V. Entrevista No. 12, septiembre 6 de 2013; 3:00 pm). Los grupos indígenas víctimas de desplazamiento forzado y los operadores jurídicos confirman la inexistencia de reparación integral, en ocasiones sólo reciben escasas indemnizaciones pero ninguna rehabilitación física, ni psicológica, ni la devolución o ampliación de sus territorios incumpliendo lo pactado en diferentes reuniones efectuadas con integrantes del gobierno. Ante estos acontecimientos, el psicólogo jurídico se encuentra en la capacidad de ofrecer asesoría y acompañamiento para que las víctimas interpongan los recursos legales establecidos por la ley como tutelas y derechos de petición, con la finalidad de que les sean restablecidos los derechos vulnerados. 
Varias situaciones de las aquí descritas empeoran el estado físico y/o psicológico de los grupos indígenas en situación de desplazamiento forzado, convirtiéndose en victimización secundaria (Echeburúa, Corral y Amor, 2004; citado en Tapias y Hernández, 201, p. 26).

El hecho de que sean ubicados en albergues inapropiados, encerrados y hacinados, puede ocasionar consecuencias para la salud física y mental, el suministro de alimentación inadecuada les produce afecciones gastrointestinales, el desplazamiento forzado acelera un choque cultural que puede causarles, en nuestro lenguaje: trastornos del ánimo y trastornos de estrés postraumático, en el de ellos: maldad de los espíritus.

Algunos operadores jurídicos entrevistados expresan que los indígenas en situación de desplazamiento forzado son vistos por la gente -ciudadanos del común-, como indigentes, evidenciándose la existencia de aislamiento, racismo y prejuicios, pero en especial la representación social del diferente como inferior, lo cual hace que algunos "blancos-mestizos" aprovechen la situación para reproducir con ellos prácticas de explotación.

Los operadores jurídicos entrevistados han criticado el que no se promueva el empoderamiento y desarrollo de sus habilidades personales. “[...] por el componente asistencialista se vuelven mendigos institucionales, ¿sí? y ojo que aclaro -mendigos institucionales- que reconocen, que dicen que no les han dado, pues alguien les da, más no los empoderan frente al proceso de reparación” (D.F.L. Entrevista No. 9, julio 17 de 2013; 2:25 pm). También, refieren los indígenas del cabildo Wounaan que los operadores jurídicos no les informan adecuadamente acerca de las rutas de atención para acceder a los servicios que brindan las instituciones y se presentan dilaciones en los procesos de retorno y devolución de sus territorios ancestrales (D.C. Mercasa. Entrevista 
No.8, junio 8 de 2013; 2:35 pm). Este tipo de informaciones, opiniones, imágenes, actitudes y prácticas, evidencia un conflicto entre la forma como los indígenas son representados por los operadores y el modo como los indígenas se representan el Estado y a sus operadores, de tal forma el conflicto armado que los hizo desplazarse se convierte para ellos en un conflicto social, cultural, institucional y legal que afecta sus modos de ser, sus personalidades y proyecto de vida, daños que podrían ser determinados a través de peritajes realizados por psicólogos jurídicos.

\section{Derecho de acceso a la justicia}

Se define acceso a la justicia, como la existencia de facilidades para que todas las personas sin discriminación alguna puedan gozar de todos los recursos y servicios que garanticen su seguridad, movilidad, comunicación y comprensión de los servicios judiciales, que garanticen una justicia pronta y cumplida (CIDH, 2011, p. 105).

Según la ONU, resolución, 4034, el derecho de acceso a la justicia consiste en que las víctimas sean escuchadas acerca de los problemas que los aquejan, con igualdad de trato ante la ley y sin ningún tipo de discriminación, esto se encuentra relacionado con la atención y asistencia de los grupos indígenas víctimas de desplazamiento forzado. El cumplimiento de las funciones, las actitudes, los recursos logísticos y los conocimientos que posea el operador jurídico hacen parte de la adecuada o inadecuada atención que brindan a las víctimas de desplazamiento forzado. Es decir, el incumplimiento de los componentes mencionados están asociados con falencias en la atención convirtiéndose en causas de victimización, como es la dilación en los

procesos, la insuficiente información, insensibilidad e incomprensión (Echeburúa, Corral y Amor 2004; citado en Tapias y Hernández, 2011, p. 26) 


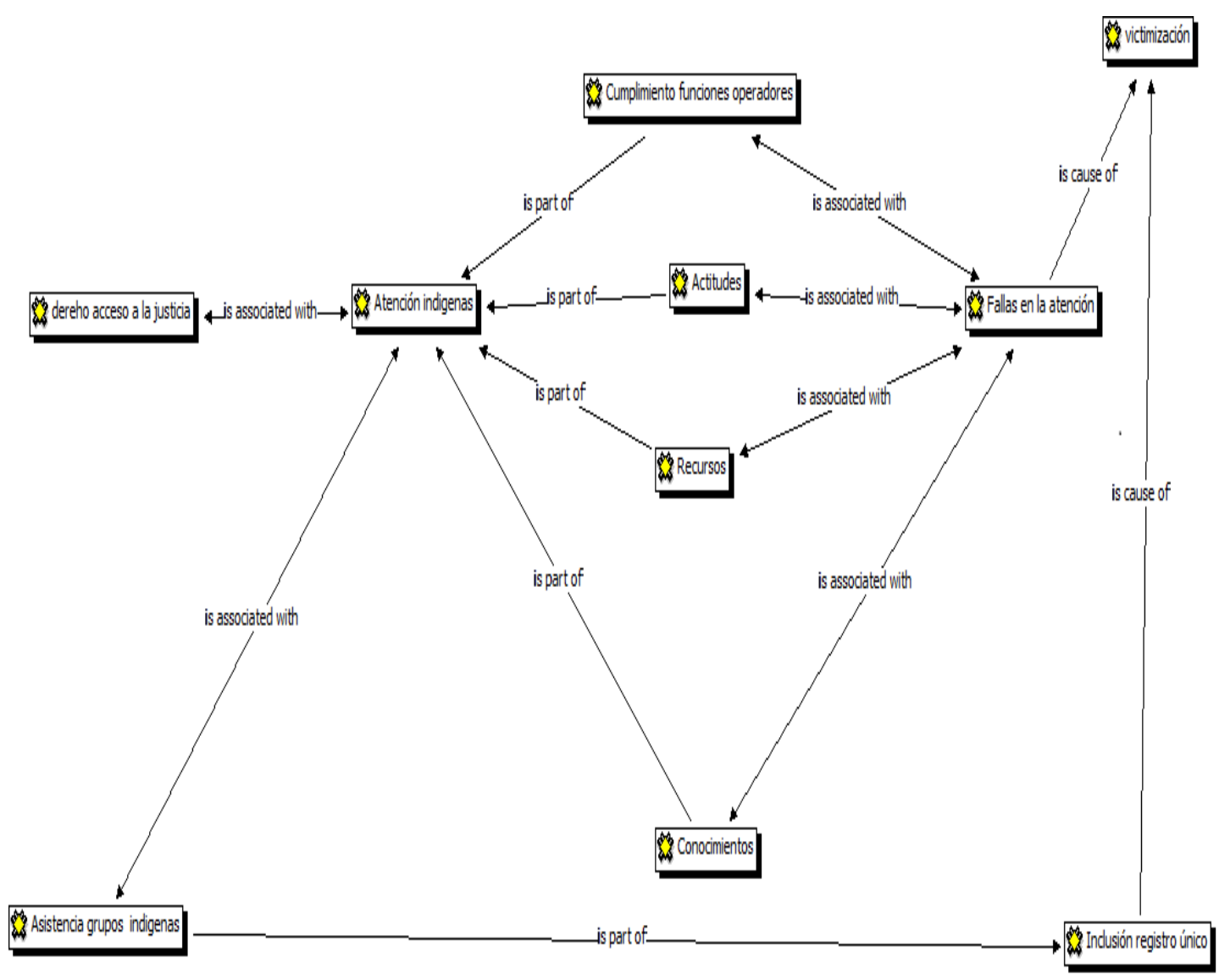

Figura 2. Categoría derecho de acceso a la justicia Fuente: Elaborado con Atlas Ti

De igual manera, la inclusión al registro único de víctimas hace parte de la asistencia a los indígenas y en el momento en que algunos de ellos son excluidos se convierten en personas victimizadas por el aparato estatal. "[...] las personas que, y grupos indígenas que siguen siendo víctimas de grupos paramilitares, no están siendo reconocidas por cuanto se tiene la visión que desde el 2000, desde la Ley de Justicia y Paz los paramilitares no existen” (S.M. Entrevista No. 3, mayo 14 de 2013; 2:40 pm).

\section{Enfoque diferencial}

El enfoque diferencial es el reconocimiento de que existen poblaciones que por sus características particulares, en razón de su edad, género, orientación sexual, 
grupo étnico y situación de discapacidad, deben recibir un tratamiento especial en materia de ayuda humanitaria, atención, asistencia y reparación integral (UARIV, 2014, p. 2)

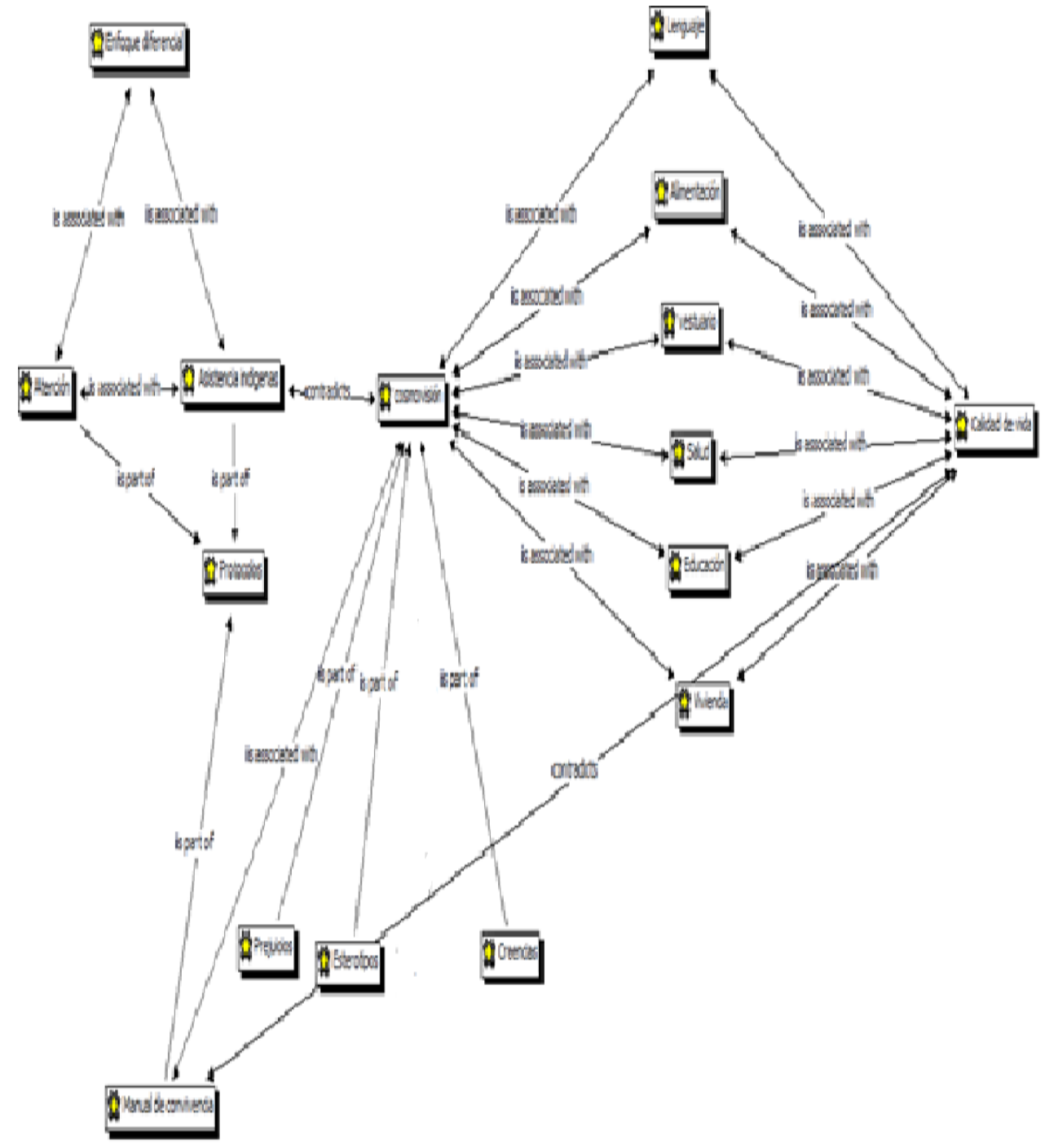

Figura 3. Categoría enfoque diferencial

Fuente: Elaborado con Atlas Ti

De esta manera, el enfoque diferencial enunciado en el artículo séptimo de la Carta Magna y en la Ley 1448 de 2011 artículo 13, consiste en reconocer que hay poblaciones con características particulares en razón de su edad, género, orientación 
sexual y situación de discapacidad. [...] El Estado ofrecerá especiales garantías y medidas de protección a los grupos expuestos a mayor riesgo de las violaciones [...] y víctimas de desplazamiento forzado.

Es así como el enfoque diferencial está asociado con la atención y asistencia que ofrecen los operadores jurídicos a los grupos indígenas víctimas de desplazamiento forzado. De acuerdo con las entrevistas realizadas a estos, se evidencia que los operadores jurídicos desconocen la cosmovisión de los indígenas, a través de la atención que ofrecen se observan fallas en la información y prácticas occidentalizadas. “[...] como le digo, aquí no hay distinción de ninguna índole, de, tanto de indígenas, no sólo de indígenas sino de todas, tanto afros como cualquier persona que venga con ese desplazamiento forzado" (C.A. Entrevista No. 2, abril 30 de 2013; 3:30 pm). Precisamente, la cosmovisión de los indígenas Wounaan hace referencia a la concepción colectiva e individual que tienen sobre el mundo físico, espiritual y el entorno en que se desarrollan, manteniendo el equilibrio ambiental y la continuidad de su patrimonio cultural, relacionados en aspectos de alimentación, educación, salud, lenguaje, vestuario, vivienda, etc., que al quedar fuera de su contexto y al desatenderse influyen en el deterioro de la calidad de vida en la que se encuentran los indígenas ubicados en Bogotá. Cabe señalar, que para brindar atención y asistencia a las mencionadas comunidades existen protocolos generales no diferenciales y manuales de convivencia que deben acatar los indígenas al encontrarse en albergues provisionales, los cuales van en contravía de su cosmovisión, contribuyendo a incrementar la problemática que padecen los indígenas en situación de desplazamiento forzado. “[...] eso ha generado muchos conflictos entre los hombres y las mujeres incluso los niños, porque están todos encerrados en unas bodegas que son los albergues donde están 
durmiendo, habitando las 24 horas del día” (L.G. Entrevista No. 10, agosto 8 de 2013; 6:45 pm).

En tal sentido, los operadores jurídicos aseveran que en Colombia existen aproximadamente 102 etnias indígenas que mayoritariamente padecen el flagelo del desplazamiento forzado, en cada una de ellas sus integrantes hablan, visten y poseen costumbres singulares, lo cual significa que para atenderlos satisfactoriamente se requiere que el Estado implemente mecanismos efectivos para acceder a la justicia, tales como suprimir los costos, formalismos y demoras para acceder a esta, fortalecer los mecanismos alternativos de justicia y la destinación de recursos suficientes por parte del gobierno. Entre otros, es necesaria la adecuada dotación de los “centros dignificar" que funcionan en la capital, mediante la asignación de mayor talento humano calificado, recursos logísticos y la construcción de protocolos que se ajusten a las necesidades de cada una de las etnias indígenas del país.

\section{Atención a indígenas}

El Estado colombiano informará y asesorará a las víctimas [...] sobre los derechos, recursos y de todos los servicios jurídicos, médicos, psicológicos, sociales, administrativos y de otra índole a los que pueden tener derecho, teniendo en cuenta las características ancestrales de cada pueblo, así como el idioma de las víctimas. Los pueblos indígenas accederán a los medios de información para divulgar los derechos... (Decreto Ley 4633 de 2011, art. 40)

De esta manera, el Decreto Ley 4633 de 2011 artículo 40 señala que la atención a los indígenas víctimas de desplazamiento forzado consiste en proporcionarles información y asesoría acerca de todos los derechos, recursos jurídicos, servicios médicos, psicológicos, administrativos y sociales que les asisten como víctimas del 
conflicto armado interno. Cabe resaltar, que la atención se relaciona con la asistencia y hace parte de la garantía del acceso a la justicia.

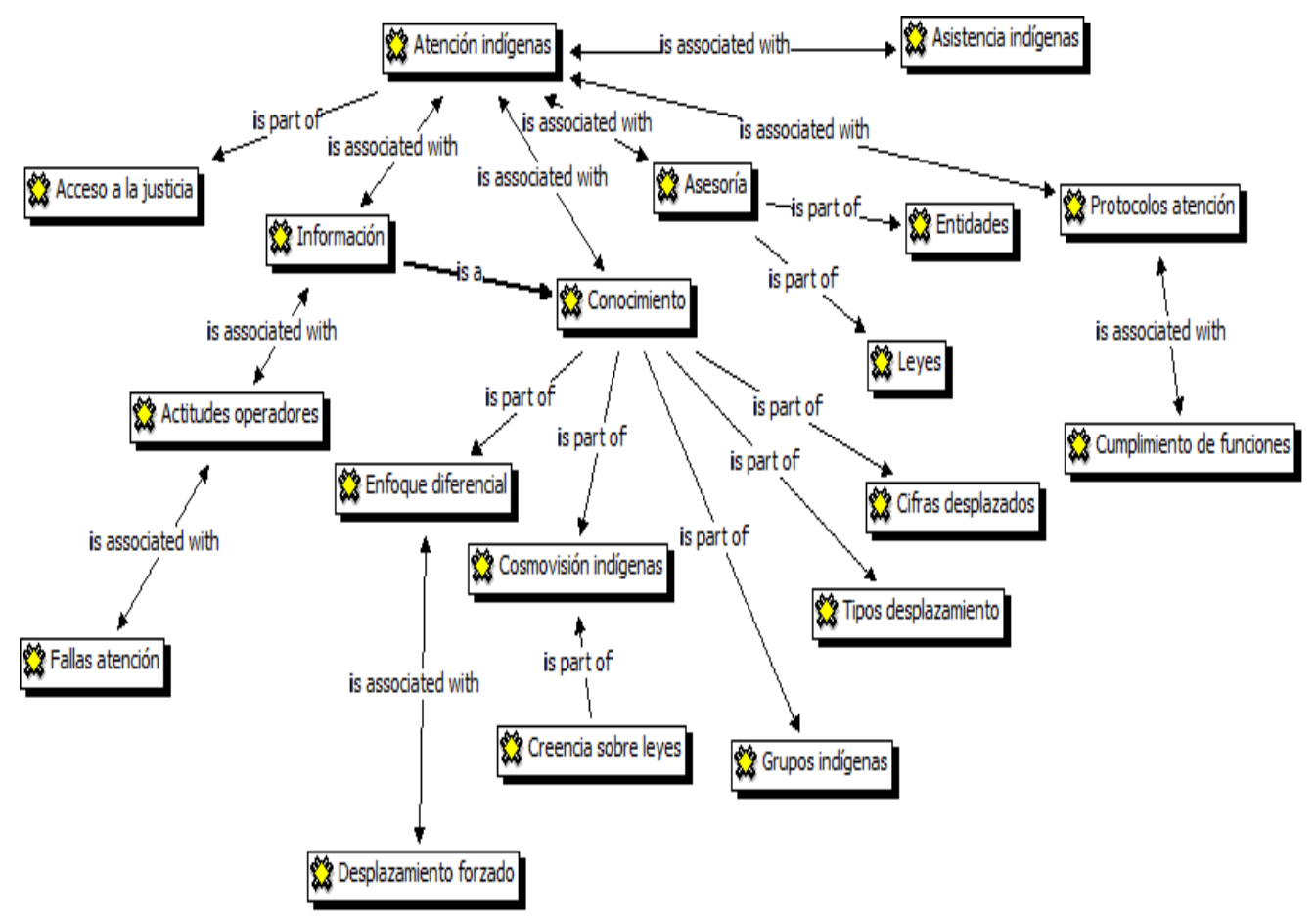

Figura 4. Categoría atención indígenas

Fuente: Elaborado con Atlas Ti

En este orden de ideas, para que los operadores jurídicos ofrezcan información y asesoría adecuada requieren poseer conocimientos sobre el enfoque diferencial, la cosmovisión de los indígenas, la existencia de las diferentes etnias, las zonas del país donde se encuentran ubicadas, las cifras de desplazados, los tipos de desplazamiento que existen, y en especial reconocer y conocer el conflicto ancestral e intergeneracional que ha existido entre los hombres "blancos-mestizos" y los indígenas, conflicto manifiesto en la estereotipa que se hace del sujeto etnizado y en la resistencia del indígena a entrar en las lógicas modernizadas que reproduce la institucionalidad. Pero sobre todo, destacar 
la diferencia en el modo como se relacionan con la justicia, aspecto en el que pueden profundizar sus investigaciones y acciones los psicólogos jurídicos.

Justamente, la atención debe ser guiada siguiendo las pautas establecidas en los protocolos que según los operadores jurídicos se encuentran en construcción en algunas entidades, los cuales son necesarios para el cumplimiento efectivo de las funciones asignadas. También, las actitudes de rechazo y desinterés que muestran algunos operadores jurídicos hacia las víctimas de desplazamiento forzado se constituyen en fallas en la atención que deben ser subsanadas y resignificadas por los operadores en trabajos de apoyo grupal por parte de profesionales como el psicólogo jurídico, en los que se les escuche frente al choque cultural al que también han sido expuestos al tratar con poblaciones histórica y culturalmente diferenciadas, labor para la que no han sido formados.

\section{Vulneración de los derechos humanos}

La ONU (2010) señala que "los Derechos Humanos son inherentes a todos los seres humanos, sin distinción alguna de nacionalidad, lugar de residencia, sexo, origen nacional o étnico, color, religión, lengua o cualquier otra condición".

En este sentido, las entrevistas realizadas a los operadores jurídicos e indígenas Wounaan, contienen relatos donde se destaca la continua vulneración de los Derechos Humanos hacia los grupos étnicos en situación de desplazamiento forzado: “[...] ese "plan patriota" entró a las costas de esta parte del medio Atrato en el Chocó y como nunca antes la guerra se metió en los territorios indígenas, en sus territorios sagrados" (E.J. Entrevista No. 11, septiembre 5 de 2013; 7:00 pm).

Es así como el derecho a la vida se encuentra continuamente vulnerado ya que varios operadores jurídicos e indígenas indican que los actores armados han llevado a 
cabo masacres en resguardos ubicados en varias zonas del territorio nacional, confirman el asesinato de algunos de sus familiares en el departamento del Chocó. "Mi cuñado de mi esposa mataron dentro de ahí, llegaron la guerrilla y los mataron, y ahí yo me vine, yo me vine para acá" (H.O. Ismari. Entrevista No. 7, junio 8 de 2013; 1:30 pm).

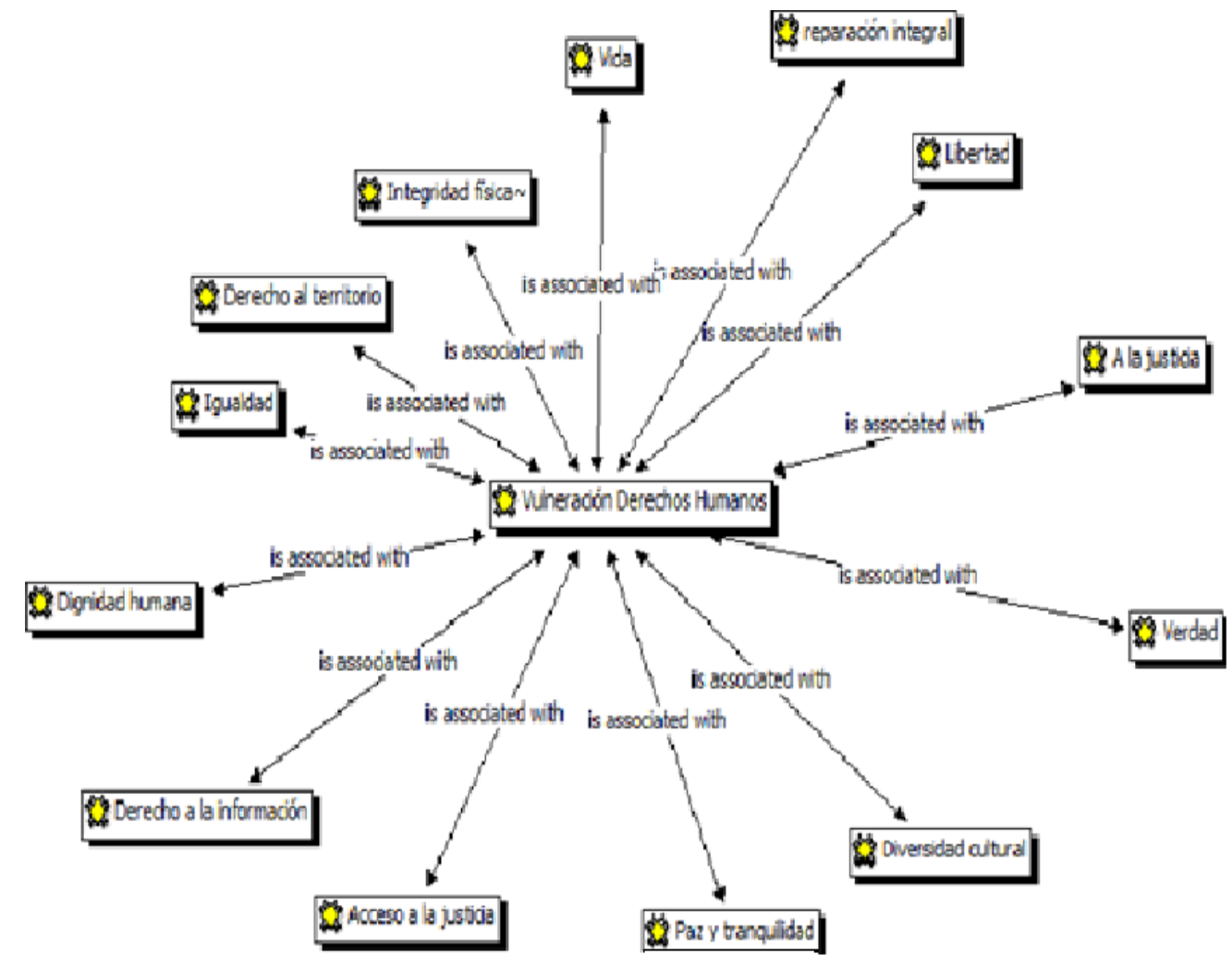

Figura 5. Categoría vulneración Derechos Humanos Fuente: Elaborado con Atlas Ti

El derecho a la libertad y libre locomoción se vulnera debido a que los actores armados restringen la movilidad de los grupos indígenas dentro de sus territorios, en ocasiones exigiéndoles un documento especial para poder dirigirse a los ríos a fin de efectuar labores de caza y pesca. El derecho a la justicia se quebranta porque narran los operadores jurídicos que la justicia penal ordinaria "no tiene la capacidad económica o logística para llevar a cabo las investigaciones de todos los casos" (S.M. Entrevista 
No. 3, mayo 14 de 2013; 2:40 pm). Igualmente, indican que existen entidades como los hospitales y el INCODER que poco cooperan en la atención de los desplazados.

Algo similar sucede con el derecho a la verdad toda vez que si la justicia no investiga, nunca se va a lograr develar los verdaderos autores intelectuales de los delitos de desplazamiento forzado cometidos en contra de los grupos indígenas. Conforme con lo referido tanto por los indígenas entrevistados como por los operadores jurídicos la reparación integral no existe, al respecto uno de ellos manifiesta: “...empiezan a mamar gallo, muchos trámites. O sea, usted horas y horas esperando a la entrada a una oficina para que lo atiendan. No, eso es... eso es falta de respeto" (D.V. Entrevista No. 12, septiembre 6 de 2013; 3:00 pm), dicen que sólo suministran indemnizaciones sin tener en cuenta la restitución de los territorios, la satisfacción, la rehabilitación y la garantía de no repetición de las conductas. Igualmente, algunos indígenas muestran desinterés en participar en los procesos de atención, asistencia y reparación brindados por el Estado, sólo piden “...Si le quitaron las tierras que se lo devuelvan y que los que cometieron los delitos que los sometan a la cárcel, pero ni eso pasa ni nada" (D.V. Entrevista No. 12, septiembre 6 de 2013; 3:00 pm).

El derecho al territorio se ve claramente infringido según lo establecido en el convenio No. 169/1991 de la OIT (Organización Internacional del Trabajo) el cual determina que el territorio de los indígenas comprende la totalidad del hábitat que estos ocupan de alguna manera. El artículo 14 del convenio 169 de 1991, señala que son propietarios y poseedores de los territorios quienes tradicionalmente los han ocupado, teniendo el gobierno la obligación de delimitarlos.

El derecho a un regreso seguro también ha sido obstaculizado por el conflicto armado, de acuerdo a lo señalado por ciertos operadores jurídicos, en los territorios 
indígenas los actores armados instalan minas antipersonales produciendo traumas físicos y psicológicos a los habitantes de los resguardos, lo que es una clara violación del derecho a la integridad física y personal de los grupos indígenas que habitan dichos territorios. "[...] por ejemplo las minas antipersona, el hecho de que un indígena vaya caminando por su territorio como fue, como lo hizo ancestralmente sus antepasados y de repente pise algo que explotó y él no sabe ni porqué" (L.G. Entrevista No. 10, agosto 8 de 2013; 6:45 pm).

En cuanto al derecho a la diversidad étnica y cultural enunciado en la Constitución Política de Colombia en el artículo séptimo, son algunas instituciones del Estado las que lo incumplen debido a que se omite la aplicación del enfoque diferencial para los indígenas víctimas de desplazamiento forzado, algunos operadores jurídicos que laboran en los "Centros Dignificar" señalan que: "atienden a todos los grupos desplazados por igual” (C.A. Entrevista No. 2, abril 30 de 2013; 3:30 pm).

Es en algunas de estas instituciones gubernamentales donde se brinda información inadecuada a los grupos indígenas víctimas de desplazamiento forzado, toda vez que los operadores jurídicos manifiestan que las bases de datos se encuentran caídas o desactualizadas y algunos no cuentan con servicio de internet para realizar los respectivos seguimientos de los procesos.

Respecto del derecho a la igualdad los indígenas Wounaan indican que reciben menos apoyo del gobierno que los afrodescendientes en cuanto a capacitación y proyectos productivos. "[...] la etnia de las negritudes hay una diferencia, trato muy distinto, porque humm hablan de lo que es el apoyo del Estado, que a veces tienen más apoyo que la etnia de los indígenas" (A.C. Piras. Entrevista No. 5, junio 8 de 2013; 11:10 am). Igualmente, señalan que algunos operadores jurídicos no los escuchan "a 
pesar de que uno les dice tres o cuatro veces hacen como el sordo" (A.C. Piras. Entrevista No. 5, junio 8 de 2013; 11:10 am), obstaculizando el derecho de acceso a la justicia.

El derecho a la dignidad humana ha sido delimitado por la Corte Constitucional a través de la sentencia T-881/02 estableciendo que posee varios ámbitos, entre ellos hace referencia a las condiciones materiales para desarrollar el proyecto de vida, donde se observa que los indígenas víctimas de desplazamiento forzado carecen de vivienda digna, generalmente habitan en albergues completamente hacinados o en casas arrendadas que se encuentran en deplorables condiciones físicas. Es así como los indígenas Wounaan entrevistados se encuentran ubicados en la localidad de ciudad Bolívar, distribuidos, según el caso, aproximadamente sesenta personas en tres casas arrendadas que físicamente están en riesgo de derrumbarse, de esta manera conviven entre quince y veinte personas hacinadas en una sala durmiendo la mayoría de ellos en pisos húmedos debido a filtraciones de agua que presentan (A.C.Piras. Entrevista No. 5, junio 8 de 2013; 11:10 am)

\section{Victimización secundaria}

Según Echeburúa, Corral y Amor (2004) es toda acción u omisión que empeore el estado físico y/o psíquico de la víctima cuando busca ayuda y se relaciona con el sistema legal, instancias en las que puede encontrar insensibilidad, incomprensión, nuevas agresiones, que se le ponga en tela de juicio, dilaciones, falta de información (Tapias, 2011; citado en Hernández, 2011, p. 26)

Por tal motivo, la inadecuada atención y asistencia a los miembros de los grupos indígenas víctimas de desplazamiento forzado, genera victimización secundaria, la cual se encuentra relacionada con la vulneración de los derechos de justicia y acceso a la 
justicia. Cabe reiterar, que la victimización secundaria agrava las enfermedades de tipo físico y psicológico de los indígenas en situación de desplazamiento forzado.

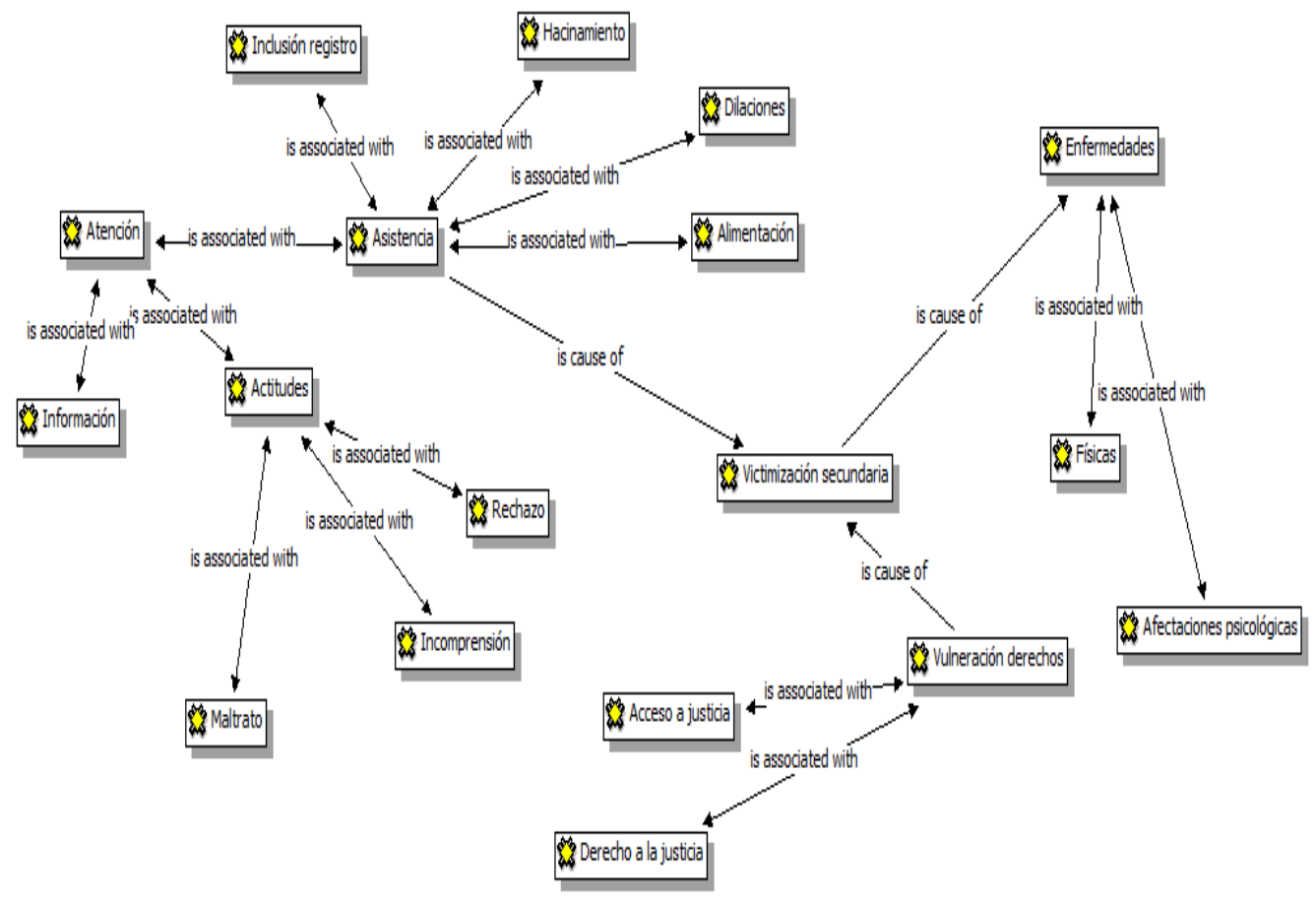

Figura 6. Categoría victimización secundaria Fuente: Elaborado con Atlas Ti

Conforme refieren varios operadores jurídicos, los indígenas "se ven muy tristes, se notan afectados, les duele mucho la situación, tienen muchos problemas psicológicos, tienen muchos problemas de alcohol, muchos de ellos se han enviciado y se dedican a la bebida" (L.G. Entrevista No. 10, agosto 8 de 2013; 6:45 pm). Algunos sufren afectaciones psicológicas que pueden convertirse en trastornos del ánimo, como sugieren otros operadores al indicar que "Generan... situaciones de mucha desesperación, de mucha angustia, de mucha tristeza, se deprimen mucho, se ponen muy tristes los indígenas cuando están fuera de su territorio por la guerra" (L.G.A. Entrevista No. 10, agosto 8 de 2013; 6:45 pm). 
Más aún, manifiestan que "se enferman porque los indígenas cuando están fuera de sus territorios, y comen mucho azúcar, los enferma enormemente...las comidas procesadas los enferman porque no es como el contexto en el que ellos históricamente han vivido y han comido" (E.J. Entrevista No. 11, septiembre 5 de 2013; 7:00 pm). Igualmente, narran que los miembros de los grupos indígenas víctimas de desplazamiento forzado "uno los ve como con esa desesperación que ellos digamos en su núcleo vivían muy bien, aquí llegan y no saben ni qué hacer” (C.A. Entrevista No. 2, abril 30 de 2013; 3:30 pm)

En cuanto al derecho a la justicia, señalan que los grupos indígenas "buscan justicia pero no la encuentran con las instituciones, las instituciones a veces nos tornamos lentas, en la atención" y algunos justifican su accionar indicando que "la justicia ordinaria penal es lenta, por cuanto tampoco tiene la capacidad económica o logística para llevar a cabo las investigaciones de todos los casos, entonces eso genera también una desesperanza en las personas". Los indígenas esperan que "los que cometieron los delitos los sometan a la cárcel, pero ni eso pasa ni nada. Y uno sale a denunciar termina señalado y terminan matándolo" (D.V. Entrevista No. 12, septiembre 6 de 2013; 3:00 pm).

Los indígenas en situación de desplazamiento forzado expresan que la atención en salud es dilatoria: “...por lo menos en los hospitales, que también se demora la atención cuando llevamos un paciente se demoran dos, tres horas esperando que ayga la atención..." (A.C. Piras. Entrevista No. 5, junio 8 de 2013; 11:10 am). De acuerdo con los relatos anteriores se muestra la continua victimización institucional que padecen los indígenas afectados por el desplazamiento forzado. 


\section{La dimensión psicosocial y psicojurídica de estas representaciones}

Es de anotar, que en la concepción de Moscovici, se plantean cuatro elementos constitutivos de las representaciones sociales: La información, la imagen, las opiniones y las actitudes, estos elementos se tomaron como guía para el análisis de la información (Zamora, 2007, p. 25).

Las RS constituyen conocimientos del sentido común que emplean algunos grupos para explicar la realidad. Es así como se evidencian similitudes entre algunos conceptos que poseen los indígenas víctimas de desplazamiento forzado y los operadores jurídicos acerca de la aplicación de las leyes: los indígenas entrevistados opinan que las leyes se incumplen "el gobierno los quiere engañar" prometiéndoles ayudas que no proporcionan como la vivienda, los proyectos productivos, la capacitaciones y talleres sobre Derechos Humanos. En el mismo sentido, los operadores jurídicos opinan que: "las leyes son ideales no funcionales, que el gobierno falla en la implementación de las mismas reflejando la ausencia del Estado" (D.V. Entrevista No. 12, septiembre 6 de 2013; 3:00 pm).

Igualmente, comparten el concepto de que la reparación integral no existe, los indígenas entrevistados manifiestan que desean volver a sus territorios pero sienten temor de ser asesinados o que se vuelva a repetir el desplazamiento forzado, debido a que los actores armados continúan vulnerando los Derechos Humanos en los resguardos del departamento del Chocó, lugar de donde proceden los indígenas Wounaan. Al respecto los operadores jurídicos opinan que el Estado no puede garantizar la reparación integral hasta que no finalice el conflicto armado interno.

De otro lado, existe una representación del indígena en medio de la función y responsabilidad que se les ha encomendado, algunos operadores jurídicos 
gubernamentales y no gubernamentales no creen que los indígenas sean víctimas de desplazamiento forzado sino que "les gusta permanecer en la ciudad, es su estilo de vida, son dependientes del Estado, son asistencialistas, la ciudad es funcional para ellos, debido a esto no desean regresar a sus territorios de origen" (D.V. Entrevista No. 12, septiembre 6 de 2013; 3:00 pm).

Al momento de mantener intercambios de lenguaje, a la mayoría de los operadores jurídicos se les dificulta comprender la cosmovisión que poseen los indígenas acerca del funcionamiento del sistema de atención estatal por cuanto las víctimas buscan respuestas efectivas y los operadores jurídicos sólo les pueden brindar información. En tal sentido, algunos de los miembros de los grupos étnicos nombrados desconocen el significado de ciertos términos empleados en el ámbito jurídico debido a que para ellos son entidades o nociones abstractas; tales como la reparación integral, el desplazamiento forzado, víctimas, justicia etc., entonces tanto los operadores jurídicos como los indígenas organizan y categorizan la información recibida para explicar la realidad, transformando lo desconocido en algo propio que es comunicado en el sentido común, éste es el anclaje expuesto por Moscovici. El anclaje se determina cuando transforman las entidades abstractas en conceptos concretos que continúan empleando en la cotidianidad, haciéndolo habitual, convirtiéndose en representaciones sociales. De tal manera, podemos afirmar que los prejuicios sobre los indígenas y la resistencia de ellos fruto del choque cultural pone en evidencia los anclajes de los conceptos que a cada uno les son necesarios para definir su lugar respecto del otro.

Teniendo en cuenta lo descrito por Hall (1997) sobre los "sistemas de representación" se muestra un intercambio de conceptos y sentidos que se efectúa a través del empleo del lenguaje, ya que es por medio de este que se construye el sentido, 
donde los operadores jurídicos y los indígenas emplean semejanzas y diferencias para relacionar, organizar y clasificar determinados conceptos con el fin de dar sentido a las cosas, objetos, personas y situaciones que surgen a través del intercambio simbólico los cuales conforman el sistema conceptual que opera como representaciones mentales que derivan en disputas por el significado, el reconocimiento y el poder. En tal sentido, los psicólogos jurídicos a través de investigaciones pueden estudiar los sistemas de representación que poseen los indígenas acerca de la justicia estatal, estableciendo la manera como se relacionan con la misma, contribución que conllevaría a establecer diálogos de saberes entre culturas, a mejorar los procesos de atención y acceso a la justicia de los indígenas víctimas del fenómeno de desplazamiento forzado.

En este orden de ideas, al realizar la codificación de las entrevistas quedó demostrado que los indígenas mantienen el concepto de que los operadores jurídicos no los atienden en debida forma y no reciben los apoyos que requieren porque estos desconocen la cultura indígena, desconocen algunas leyes y creen que todos ellos no saben hablar español. De la misma forma, los operadores jurídicos reconocen que carecen de expertos para la comprensión de la cosmovisión de los grupos indígenas, muchos quisieran solucionar los diferentes problemas que les acarrea el delito del desplazamiento forzado pero se muestran impotentes por la falta de recursos técnicos, humanos, logísticos, capacitación en enfoque diferencial y actualización en algunas leyes expedidas relacionadas con dicho tema. Además algunos añaden que son evaluados por la cantidad de personas que atienden sin tener en cuenta la calidad del servicio que ofrecen.

La sumatoria de las representaciones negativas que poseen los operadores jurídicos, como los indígenas, acerca del acceso a la justicia que se les debe a los 
indígenas en el marco de la Justicia Transicional ilustra la presencia de hábitos de pensamiento, de representaciones y de ordenes discursivos -en el sentido como lo plantea Foucault-, de disputas entre significados, poderes, institucionales y culturales que obstaculizan el acceso a la justicia y a los derechos que tienen los indígenas, máxime cuando es un conflicto que les es ajeno por cuanto la mayoría de ellos lo han considerado un conflicto que refleja la disputa entre los mismos mestizos que se creen y obran como blancos. 


\section{Conclusiones}

El presente estudio deja al descubierto la importancia y necesidad que representa para las entidades gubernamentales y no gubernamentales conocer y comprender las representaciones sociales de los operadores jurídicos e indígenas afectados por el desplazamiento forzado, a fin de facilitar su acceso a la justicia. Dado que algunos operadores jurídicos muestran actitudes de rechazo hacia los indígenas y desinterés durante la atención que ofrecen a las víctimas de desplazamiento forzado, dificultando con ello el derecho de acceso a la justicia estatal. También se observa la necesidad de implementar el enfoque diferencial que rige la atención de los grupos étnicos.

El núcleo de representaciones articulado en las categorías que emergieron en el estudio cualitativo: derecho de acceso a la justicia, enfoque diferencial, atención al indígena, vulneración de los derechos humanos y victimización secundaria, muestran un encadenamiento de significados que crea un entramado de violencia simbólica en el sentido propuesto por Pierre Bordieu. Toda vez que el sistema de justicia estatal se encuentra establecido para ser cumplido por la totalidad de los pobladores colombianos, sin tener en cuenta las diferencias culturales que caracterizan a las comunidades indígenas. Lo que significa que estos deben subordinarse a las lógicas jurídicas estatales, desconociendo su autonomía y por ende vulnerando sus derechos fundamentales.

El desconocimiento del acceso a los derechos y de la especificidad de la realidad del indígena conduce necesariamente a aplicar eficazmente el enfoque diferencial que puede orientar el trato, la atención y respuesta a las demandas y derechos de la población vulnerada, así sin enfoque diferencial la atención al indígena es de baja calidad o si se quiere, los indígenas en lugar de encontrarse con la atención que les es debida, se 
encuentran con una atención inadecuada del Estado que quiere por medio de sus funcionarios y operadores que se comporten como "blancos-mestizos".

En este sentido, la atención inadecuada, la falta de formación de los operadores jurídicos se traduce en violencia simbólica, en vulneración de sus derechos y en consecuencia en victimización secundaria, el remedio resulta tan nocivo como la enfermedad.

El disponer de psicólogos jurídicos en sus equipos de trabajo, con el fin de que asesoren, capaciten y acompañen a los operadores jurídicos como a los grupos indígenas víctimas de desplazamiento forzado, podría propiciar el mejoramiento de los procesos de atención, asistencia, reparación integral y acceso a la justicia. Toda vez, que estos pueden integrar en su formación el cuidado del otro, la escucha, el conocimiento de normas jurídicas, elaboración de duelos, de peritajes psicosociales y la aplicación del enfoque diferencial.

Precisamente, un punto crítico se refiere a la falta de conocimiento del enfoque diferencial, ya que presentan déficits en la capacitación que reciben los operadores jurídicos, desconociendo ciertas condiciones particulares que poseen las personas que componen las diversas etnias indígenas, concernientes a la alimentación, vestuario, vivienda, lenguaje, información que ofrecen y nivel de escolaridad. Situación que se exacerba cuando algunas de las víctimas indígenas poseen títulos profesionales. Se exacerba porque en el imaginario del operador está anclada la representación del indígena como ignorante, primitivo.

Cabe señalar, que al momento de la realización del presente estudio, el Centro Dignificar de la Localidad de Suba, carecía de protocolos adecuados para la atención de las etnias indígenas. Según lo referido por los operadores jurídicos entrevistados, para la 
atención de todas las personas víctimas de desplazamiento forzado utilizaban el mismo enfoque psicosocial, sin pensar en un posible enfoque integral para estos casos que demanda la intersección de lo étnico-jurídico-psico-social.

Encontramos que existen diferencias y marcadas distancias entre la representación de justicia que tienen los indígenas respecto de la concepción que poseen los operadores jurídicos, aquí es donde es posible y se hace necesario que los psicólogos jurídicos investiguen acerca de los sistemas de representación empleados por las víctimas a fin de mejorar la atención y acceso a la justicia occidental de dichas comunidades étnicas.

En esta brecha entre la representación inadecuada del indígena, la ausencia del enfoque diferencial y la falta de comprensión de la cosmovisión de los pueblos afectados por estos hechos, es donde el psicólogo jurídico puede proponer un puente entre la representación de la ley y del indígena en la subjetividad de los operadores y los indígenas mismos, dando pie a pensar los aportes de una etnopsicología jurídica que se ocupe de las relaciones entre la identidad, la subjetividad y la justicia para y con los pueblos indígenas.

En cuanto a los operadores jurídicos que laboran en organizaciones no gubernamentales, si bien no es finalidad de esta investigación evaluar la coordinación interinstitucional, se encontró que debería existir mayor acoplamiento entre las diversas ONG y las instituciones estatales a fin de optimizar la atención y evitar la duplicidad que fortalece el asistencialismo.

También, los operadores dejaron entrever una ambigüedad, si bien indicaron que la responsabilidad de la atención a las personas desplazadas recae en las instituciones gubernamentales, muchas veces son las ONG las que asumen esta labor. Generalmente, 
las diferentes ONG ofrecen orientación jurídica a fin de que los indígenas víctimas de desplazamiento forzado interpongan derechos de petición y tutelas para el restablecimiento de los derechos de las personas afectadas.

En tal sentido, los integrantes de los grupos indígenas también denunciaron que las diferentes ONG se dedicaban a captar recursos económicos en beneficio propio, razón por la cual muchos de ellos prefirieron dejarlas de lado, aduciendo que la poca asistencia que recibieron fue brindada por parte de los "Centros Dignificar" o en ocasiones fue brindada por personas y empresas particulares.

Igualmente, los operadores jurídicos de las entidades gubernamentales indican que los funcionarios de las diferentes ONG asesoran a las víctimas para que interpongan demandas en contra del Estado, otros afirman desconocer a qué se dedican o incluso ponen en duda la existencia de las mismas en la capital de la república. Estos operadores jurídicos, manifestaron la falta de cooperación existente entre las diversas instituciones para la atención de las víctimas de desplazamiento forzado, señalando expresamente al INCODER y la Red Pública de Hospitales de Bogotá por la tardanza en las respuestas.

Así, encontramos que en torno a la representación del indígena en situación de desplazamiento forzado y su acceso a la justicia, existe una disputa entre los operadores jurídicos gubernamentales y los no gubernamentales; entre los indígenas y los operadores jurídicos gubernamentales; y entre los indígenas y los operadores jurídicos no gubernamentales; de tal manera que la representación del proceso de acceso a la justicia implicó e implica una representación del otro, del diferente, como representantes de políticas e instituciones ineficientes, ineficaces, estigmatizantes, también como corruptas, asistencialistas o dependientes; un conjunto de representaciones que 
presupone la mala fe, la mala voluntad en los actores del sistema de Justicia Transicional creado para producir verdad, justicia, reparación y no repetición.

La dinámica de dichas representaciones provee a la vez un sistema de violencia simbólica que se convierte en violencia institucional en medio de la cual queda atrapado el sujeto étnico, victimizado por segunda vez bajo la generación de condiciones que podrían propiciar la consecuente revictimización en la medida que sean desacertados los procesos de restitución y las garantías de no repetición.

Respecto de las representaciones sociales, los operadores jurídicos de las entidades gubernamentales y no gubernamentales entrevistados generalmente se dedican a ofrecerles información y orientación a los grupos indígenas en situación de desplazamiento forzado, en otros términos, hacen labores de mensajería, a fin de que acudan a diferentes instituciones en busca de asistencia, toda vez que carecen de la capacidad para tomar decisiones eficaces, que realmente se encuentran a cargo de los altos funcionarios estatales. Mientras que los miembros de los grupos indígenas indicados, inicialmente mantienen el concepto y como corresponde la exigencia de que estos se encuentran instalados en dichos sitios para ofrecerles soluciones efectivas a sus necesidades reales ya que se requieren resultados concretos, pero finalmente, al encontrarse con diferentes barreras culturales, con prejuicios y procesos burocráticos como el exceso de trámites y requisitos para acceder a la justicia consideran que los operadores jurídicos los desatienden, les incumplen y desconocen su cultura. En estas condiciones, el sistema de Justicia Transicional antes que una solución incrementa la problemática de los indígenas desplazados y empeora la relación del estado con el indígena, como la representación negativa que estos han tenido del estado "blancomestizo" que siempre ha buscado expropiarlos, colonizarlos, desconocerlos. 
De acuerdo a lo expresado por los indígenas, los operadores jurídicos consideraron que la atención y reparación de las nombradas comunidades se sigue efectuando mediante la entrega de folletos con información acerca de los derechos humanos, permitiéndoles que narren historias sobre el desplazamiento forzado, asistiendo a reuniones, o tomándoles fotografías; lo que catalogaron como una falta de respeto, una burla en la que son objeto del registro de indicadores de gestión sin acciones concretas, reales. Toda vez, que lo que realmente solicitan dichas comunidades étnicas es la delimitación de sus territorios, la ampliación de los resguardos, y que los responsables de los desplazamientos forzados sean castigados y encarcelados, que las tierras despojadas les sean devueltas, que los dejen tranquilos y les garanticen la convivencia pacífica en sus resguardos indígenas. 


\section{Recomendaciones}

Teniendo en cuenta los resultados de la investigación, se hace necesaria la asesoría y capacitación de los diferentes operadores jurídicos en cuanto al conocimiento, el cumplimiento de las normas y la aplicación del enfoque diferencial, labor que podría ser realizada por los psicólogos jurídicos que poseen dichas competencias.

Los psicólogos jurídicos pueden vincularse en este escenario realizando aportes en cuanto a la mediación en los conflictos jurídicos que se presentan entre las víctimas y victimarios, creando y aplicando modelos alternativos de justicia que en nuestro país tienen mucho camino por explorar. Igualmente, podrían orientar a las víctimas en cuanto al suministro de rutas de atención efectivas incluyendo el respectivo acompañamiento integral de las mismas. También, efectuando peritajes que coadyuven a la restitución y el restablecimiento de los derechos vulnerados de los integrantes de las comunidades indígenas en situación de desplazamiento forzado.

Se hace necesario que los psicólogos jurídicos investiguen acerca de los sistemas de representación empleados por las víctimas a fin de mejorar la atención y acceso a la justicia occidental de los grupos indígenas víctimas de desplazamiento forzado. 


\section{Referencias}

Acción Social (2011) Registro único de población desplazada. Recuperado el 12 de octubre, de 2012, de www. Accionsocial.gov.co/

ACNUR. Alto comisionado de las Naciones Unidas para los Refugiados (2009). Pueblos indígenas en Colombia. Recuperado el 20 de abril de 2014, de http://www.acnur.org/t3/pueblos-indigenas/pueblos-indigenas-en-colombia/

ACNUR. Alto comisionado de las Naciones Unidas para los Refugiados (2012). Situación Colombia indígenas. Recuperado el 22 de abril de 2014, de: http://www.acnur.org/t3/fileadmin/scripts/doc.php?file=t3/fileadmin/Documento s/RefugiadosAmericas/Colombia/2012/Situacion_Colombia_-_indigenas_2012

Aguilera, A. (2001) Análisis de la Ley 387 de 1997: su Impacto psicosocial en la población desplazada. Reflexión Política, 5, 0124-0781. Recuperado el 5 de mayo. De 2012, de http://redalyc.uaemex.mx/redalyc/src/inicio/ArtPdfRed.jsp?iCve=11000508

Aguilar, A. (2008) Marco Teórico y Aspectos Generales Relativos al Fenómeno de Desplazamiento Interno Forzoso Capítulo III. Desplazamiento interno forzoso en Colombia. Eleuteria, 1. Recuperado el 7 de jun. De 2012, http://dialnet.unirioja.es/servlet/oaiart?codigo=2596341

Alcaldía Mayor de Bogotá, Plan de acción Distrital de prevención, protección y reparación integral a las víctimas 2013-2016; Alta Consejería para los Derechos de las Víctimas, la Paz y la Reconciliación. Recuperado el 22 de abril de 2014, de:http://www.alcaldiabogota.gov.co/sisjur/adminverblobawa?tabla=T_NORMA 


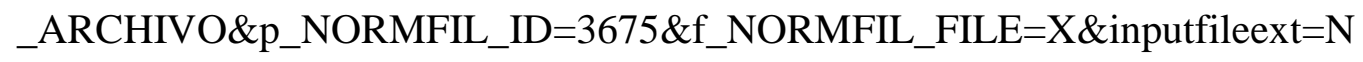

ORMFIL_FILENAME

Alcaldía Mayor de Bogotá (2012). Proyecto de Presupuesto 2013 Bogotá, Distrito Capital. Anexo 4 Secretaría Distrital de Hacienda Dirección Distrital de Presupuesto. Recuperado el 22 de abril de 2014, de: http://impuestos.shd.gov.co/portal/page/portal/portal_internet_sdh/presupuesto/pr oyectos_pre/Proyecto\%20Presupuesto\%202013/Conflicto_Armado.pdf

Amar, J., Abello, R., Madariaga, C., \& Ávila, J. (2010). Relación entre redes personales y calidad de vida en individuos desmovilizados del conflicto armado colombiano. Universitas Psychologica, 10, 1657-9267. Recuperado el 3 de jul. De 2012, de http://revistas.javeriana.edu.co/sitio/psychologica/sccs/resultados_busqueda.php? pagina $=3 \&$ criterio $=$ resumen $\&$ valor $=$ desplazamiento $\% 20$ afrodescendientes $\% 20 \mathrm{c}$ olombia

Ball, S. (1993) Foucault y la educación. Disciplinas y saber. España: Ediciones Morata. S.L. Recuperado el 24 de 2014, de: http://patriciolepe.files.wordpress.com/2009/12/s-j-ball-foucault-y-la- cion_3.pdf

Banchs, M (2001) Jugando con las ideas entorno a las representaciones sociales, Revista venezolana de sociología y antropología, 11, 30. Recuperado el 13 de octubre de 2012, de http://redalyc.uaemex.mx/pdf/705/70512127003.pdf

Benavides, F. (2009) La movilización de los pueblos indígenas y la lucha por sus derechos en Colombia. Institut Catalá Internacional per la Pau, 2013.5793. Recuperado el 9 de jun. De 2012, de http://www.recercat.cat//handle/2072/152122 
Beristaín, C. (2008) Diálogos sobre la reparación experiencias en el sistema interamericano de derechos humanos, Tomo 2. San José, C. R.: Instituto Interamericano de Derechos Humanos

Castrillón, A. (2009). Reseña de "El desplazamiento forzoso en Colombia: un camino sin retorno hacia la pobreza" de Ana María Ibáñez Londoño. Revista de Economía Institucional, 11, 20. Recuperado el 6 de mayo. De 2012, de http://redalyc.uaemex.mx/src/inicio/ArtPdfRed.jsp?iCve=41911877019

Chávez, Y., \& Falla, U. (2005). Representaciones sociales acerca del retorno en población en situación de desplazamiento asentada en el municipio de Soacha. Tabula Rasa Revista de Humanidades, 003, 1794- 2489. Recuperado el 9 de jun. De 2012 , de http://redalyc.uaemex.mx/redalyc/src/inicio/ArtPdfRed.jsp?iCve=39600314

Colombia (1998) Ley 387 de 1997 por la cual se adoptan medidas para la prevención del desplazamiento forzado; la atención, protección, consolidación y esta estabilización socioeconómica de los desplazados internos por la violencia en la República de Colombia. Bogotá: Temis S. A.

Comisión Interamericana de Derechos Humanos, CIDH. (2011) Acceso a la justicia para mujeres víctimas de violencia sexual en Mesoamérica. OEA/Ser.L/V/II. Doc. 63. Recuperado el 24 de abril de 2014, de: http://www.cidh.oas.org/pdf\%20files/MESOAMERICA\%202011\%20ESP\%20FI NAL.pdf

Constitución política de Colombia (2000) Bogotá: Temis S.A.

Colombia. Corte Constitucional. Sentencia C- 1027/02. Recuperado el 30 de noviembre de 2012, de http://www.corteconstitucional.gov.co/relatoria/2002/C-1027-02 
Colombia. Corte Constitucional. Sentencia C- 163/99. Recuperado el 29 de septiembre de 2013 de www.corteconstitucional.gov.co/

Colombia. Código Penal Colombiano. Ley 5599/00. Bogotá: Temis S. A.

Colombia. Corte Constitucional. Sentencia T-476/98. Recuperado el 25 de agosto de 2013 de www. corteconstitucional.gov.co/relatoría/

Colombia. Convenio No. 169/1991 OIT (Organización Internacional del Trabajo). Recuperado el 12 de agosto de 2013 de www.oit.org/

Cuchumbé, N., \& Vargas, J. (2008). Reflexiones Sobre el sentido y génesis del desplazamiento forzado en Colombia. Universitas Humanística, 65, 0120- 4807 $\begin{array}{lllllll}\text { Recuperado el de } & \text { de }\end{array}$ http://redalyc.uaemex.mx/redalyc/src/inicio/ArtPdfRed.jsp?iCve=79106509

Declaración Universal de los Derechos Humanos (s.f.). Recuperado el 12 de enero de 2013, de www.un.org/

Decreto 4800 de 2011. Recuperado el 12 de enero de 2013 de http://www.alcaldiabogota.gov.co/sisjur/normas/Norma1.jsp?i=45063

Departamento Administrativo Nacional de Estadística (s.f.) La visibilizaría estadística de los grupos étnicos colombianos. Recuperado el 8 de octubre, de 2012, de http://www.dane.gov.co/files/censo2005/etnia/sys/visibilidad_estadistica_etnicos

El Tiempo. 25 de abril de 2014. "Así fue el cara a cara de Santos con los indígenas del Cauca”. Colombia. Recuperado el 23 de abril de 2014, de: http://m.eltiempo.com/colombia/occidente/as-fue-el-cara-a-cara-de-santos-conlos- indgenas-del-cauca/12132767.

Farr, R. (1986). Las representaciones sociales. En Moscovici, S. (Ed.). Psicología Social II. Barcelona: Paidós. 
Fernández, H., y Sánchez, J. (2010). Características del desplazamiento forzado en Colombia. Revista Lebret, 2. Recuperado el 6 de jul. De 2012, de http://200.21.227.132/inicio/publicaciones/div_econo/pdflebret2/caracteristicas_ desplazamiento.pdf

Ferrer, N. (2010) El acceso a la justicia como elemento indispensable del ejercicio de la ciudadanía femenina. Opinión jurídica, 9, 17. Recuperado el 4 de noviembre de 2012, de http://www.redalyc.org/buscador/search.jsp?query=acceso+a+la

Giménez, G. (1997) La sociología de Pierre Buordieu. UNAM. Recuperado el 24 de abril de 2014, de: http://observatoriosocial.udenar.edu.co/?page_id=702

González, A. (2010). Viajeros de ausencias: desplazamiento forzado y acción colectiva en Colombia. Tesis Doctoral. Universidad Complutense de Madrid. Recuperado el 9 de jun. De 2012, de http://eprints.ucm.es/11073/ Guevara, R. (2003). La nueva colonización urbana. El desplazamiento forzado. Anuario americanista europeo, 1, 1729-9004. Recuperado el 9 de jun. De 2012, de http://dialnet.unirioja.es/servlet/oaiart?codigo=3166039

Guevara, D. (2011). Discursos y disciplinamiento de la pobreza en la población desplazada por la violencia en Colombia. Obets. Revista de Ciencias Sociales, 6, 2. Recuperado el 9 de jun. De 2012, de http://rua.ua.es/dspace/handle/10045/20545

Gutiérrez, C. (2010) Revisión sobre la definición de psicología jurídica. Revista Diversitas -Perspectiva Psicológica, 6, 2. Recuperado el 10 de abril de 2013, de mail-attachment.googleusercontent.com/attachment/?ui=2\&ik=010680

Gutiérrez, A (2004) Poder, hábitus y Representaciones: recorrido por el concepto de violencia simbólica en Pierre Bourdieu. Revista complutense de educación. 15, 1. 
Recuperado el 20 de mayo de 2013, de http://revistas.ucm.es/index.php/RCED/article/view/RCED0404120289A/16345

Hall, S. (1997) El trabajo de la representación. Instituto de estudios peruanos. Recuperado el 4 de marzo de 2013, de http://metamentaldoc.com/14_El_trabajo_de_la_representacion_Stuart_Hall.pdf

Hernández, G. (2011) Psicología jurídica iberoamericana. Bogotá: Manual Moderno

Hernández, R., Fernández, C. \& Baptista, P. (2010). Metodología de la investigación. México: McGraw- Hill

Hernández, A., \& Gutiérrez, M. (2008) Vulnerabilidad y exclusión: condiciones de vida, situación de salud y acceso a servicios de salud de la población desplazada por la violencia asentada en Bogotá -Colombia 2005. Gerencia y Políticas de Salud, 7, 014. Recuperado el 9 de jul. De 2012, de http://redalyc.uaemex.mx/redalyc/src/inicio/ArtPdfRed.jsp?iCve=54571407

Ibáñez, A., \& Querubín, P. (2004). Acceso a tierras y desplazamiento forzado en Colombia. CEDE, 23, 1657-5334. Recuperado el 9 de jun. De 2012, Recuperado el 9 de jun. De 2012, de http://economia.uniandes.edu.co/publicaciones/d2004-2

Ibáñez, A., \& Velásquez, A. (2008). El Impacto del desplazamiento forzoso en Colombia: Condiciones socioeconómicas de la población desplazada, vinculación a los mercados laborales y políticas públicas. CEPAL. Publicación de las Naciones Unidas, 1564-4162. Recuperado el 4 de jun. De 2012, de http://www.eclac.org/publicaciones/xml/2/35022/sps145-

Informe anual sobre derechos humanos en Chile (2007). Hechos 2006. Recuperado el 20 de septiembre de 2013, de http://www.derechoshumanos.udp.cl/wpcontent/uploads/2009/07/justicia_ddhh_200811.pdf 
Jaraba, B (s.f.) El individuo refutado. La teoría de la práctica de P. Bourdieu como alternativa de integración entre la psicología y la historia. Recuperado el 20 de mayo de 2013, de http://unal.academia.edu/BrunoJaraba

Jodelet, D. (1986). La Representación social: fenómenos, concepto y teoría. En López, M. (2007). Efectos de la regionalización de la política de seguridad democrática para el desplazamiento en las fronteras de Colombia. Colombia Internacional, 65. Recuperado el 9 de jun. De 2012, de http://dialnet.unirioja.es/servlet/oaiart?codigo=2345402

Lair, E. (2000). Colombia: una guerra contra los civiles. Revista internacional, 49-50. $\begin{array}{llllll}\text { Recuperado } & \text { el } & 23 & \text { de } & \text { abril } & \text { de }\end{array}$ http://colombiainternacional.uniandes.edu.co/view.php/375/index.php?id=375

Lora, M. (2011) la representación de la violencia política, en tres novelas colombianas de la segunda mitad del siglo xx. Tesis doctoral. Recuperado el 23 de abril de 2014,de: //www.colombianistas.org/Portals/0/Publicaciones/Tesis_Marta_Cecilia

Melo, J. (1996) Historia de Colombia la dominación española. Presidencia de la República; Imprenta Nacional de Colombia. Recuperado el 23 de abril de 2014, de: http://www.banrepcultural.org/blaavirtual/historia/hicol/hico3.htm

Mireles, O. (2011) Representaciones sociales: debates y atributos para el estudio de la educación. Sinéctica, 36, 1665-109x. Recuperado el 18 de octubre de 2012, de: http://www.scielo.org.mx/scielo.php?pid=S1665-\&script=sci_arttext

Moscovici, S. (Ed.). Psicología social, II. Barcelona: Paidós.

Meertens, D. (2002) Desplazamiento e identidad social. Revista de estudios sociales, 011. Recuperado el 5 de jun. De 2012, de http://redalyc.uaemex.mx/redalyc/src/inicio/ArtPdfRed.jsp?iCve=81501113 
Mendoza, A., \& González, J. (2010). El desplazamiento forzado en Colombia y la intervención del Estado: una mirada desde el goce efectivo de derechos y los factores asociados a su realización. Centro de Estudios sobre Desarrollo Económico CEDE, 44. Recuperado el 9 de may. De 2012, de http://economia.uniandes.edu.co/publicaciones/dcede2010-44.pdf

Montealegre, R. (2004) La comprensión del texto: sentido y significado. Revista latinoamericana de psicología, 36,002. Recuperado el 25 de septiembre,de 2012, de http://redalyc.uaemex.mx/src/inicio/ArtPdfRed.jsp?iCve=80536205\#

Montero, R. (s.f.) Los pueblos indígenas en Colombia y su inmersión en el proceso censal. Revista de la información básica, 1, 1. Recuperado el 13 de octubre, de $2012 \mathrm{de}$ http://www.dane.gov.co/revista_ib/html_r1/articulo8_r1.htm

Mora, M. (2002) La teoría de las representaciones sociales de Serge Moscovici. Athenea digital, 2. Recuperado el día 10 de octubre de 2012, de http://www.academia.edu/214897/La_Teoria_de_las_Representaciones_Sociales _de_Serge_Moscovici

Moscovici, S. (1986). Psicología Social, I. Barcelona: Paidós.

Moñivas, A (1994) Epistemología y representaciones sociales: concepto y teoría. Revista de psicología general y aplicada, 47 (4), 409-419. Recuperado el día 06 de octubre de 2012, de dialnet.unirioja.es

OIDHACO, (2013). En Colombia el año 2013 empieza con desplazamiento masivo. Recuperado el 20 de abril de 2014, de http://www.oidhaco.org/?art=1531\&lang=es

O.M.S. (2002) Organización Mundial de la Salud. Informe mundial sobre violencia y la salud. Recuperado el 2 de enero de 2013, de http://www.who.int/es/ 
ONU (1985) Resolución 4034. Recuperado el 10 de enero de 2013, de http://www2.ohchr.org/spanish/law/delitos.htm

Oslender, U. (2010). La Banalidad del desplazamiento: de peleas estadísticas y Vacíos en la representación étnica del desplazamiento forzado en Colombia. Universitas Humanística, 69. Recuperado el 6 de jun. De 2012, de http://www.redalyc.org/src/inicio/ArtPdfRed.jsp?iCve=79118943008

Páez, D. \& Carbonero, A. (1993) Afectividad, cognición y conducta social. Psicothema, 5, 0214- 9915. Recuperado el 8 de octubre de 2012, de http://www.unioviedo.es/reunido/index.php/PST/article/view/7185/7049

Palacios, A (2012) Representaciones sociales de grupos culturales diversos. Ciencias sociales Unisinos, 48,3. Recuperado el 12 de mayo de 2013, de http://www.redalyc.org/articulo.oa?id=93824899001

Parales, C., \& Vizcaíno, M. (2007) Las relaciones entre actitudes y representaciones sociales: elementos para una integración conceptual. Revista latinoamericana de psicología, 39, 002. Recuperado el 07 de octubre, de 2012, de http://redalyc.uaemex.mx/pdf/805/80539210.pdf

Peces-Barba, G. (1987) Los operadores jurídicos. Revista de la Facultad de Derecho de la Universidad Complutense, 72. Recuperado el 2 de marzo de 2013, dehttp://earchivo.uc3m.es/bitstream/10016 Archivo abierto institucional de la $\begin{array}{llll}\text { Universidad } & \text { Carlos } & \text { III } & \text { de }\end{array}$ /10453/1/operadores_Peces_RFDUC_19861987.pdf

Perera, M. (s.f.) A propósito de las representaciones sociales. Apuntes teóricos, trayectoria y actualidad. Recuperado el 12 de octubre de 2012, de 
http://biblioteca.clacso.edu.ar/ar/libros/cuba/cips/caudales05/Caudales/ARTICU

\section{$\underline{\text { LOS/ArticulosPDF/02P075.pdf }}$}

Pérez, G (2006) Las organizaciones No Gubernamentales-ONG- conceptualización y contextualización. Medellín: Universidad Nacional

Piña, J. \& Cuevas, J. (2004) La teoría de las representaciones sociales su uso en la investigación educativa en México. Perfiles educativos, 26, 105-106. Recuperado el 15 de octubre, de 2012, de WWW. Scielo.org/

Quintero, M., \& Vasco, E. (2007) Justificaciones y sentimientos morales de jóvenes universitarios y jóvenes desplazados acerca de las acciones justas e injustas. Acta Colombiana de Psicología, 10. Recuperado el 9 de jun. De 2012, de http://redalyc.uaemex.mx/redalyc/src/inicio/ArtPdfRed.jsp?iCve=79810110

Rivera, Maturana, G., Guzmán, J. (2009) Sisdeon: Un sistema de información sobre el desplazamiento forzado en Colombia mediante el uso de ontologías. Avances en Sistemas e Informática,6. Recuperado el 9 de jun. De 2012, de http://dialnet.unirioja.es/servlet/oaiart?codigo=3708509

RAE (2010) Diccionario de la Real Academia de la Lengua Española. Recuperado el 4 de febrero de 2013, de http://xn--realacademiaespaola-b4b.es/rae.html

Revilla, M (2002) Las ONG y la política. Madrid: ediciones Istmo

Rodríguez, T. (2003) El debate de las representaciones sociales en la psicología social.

Revista del colegio de Michoacán, 24, 93. Recuperado el 11 de octubre, de 2012, de http://redalyc.uaemex.mx/pdf/137/13709303.pdf

Rodríguez, T., \& García, M. (2007) Representaciones sociales: Teoría e investigación. México: Universidad de Guadalajara 
Ruiz, N. (2007). El Desplazamiento Forzado en el Interior de Colombia: caracterización sociodemográfica y pautas de distribución territorial 2000-2004. Tesis Doctoral. Universidad Autónoma de Barcelona. Recuperado el 9 de jun. De 2012, de http://www.tdx.cat/handle/10803/4975

Sacipa, S. (2003). Lectura de los Significados en Historias del Desplazamiento y de una Organización Comunitaria por la Paz. Universitas Psychologica, 2. Recuperado el 4 de jun. De 2012, de http://redalyc.uaemex.mx/redalyc/src/inicio/ArtPdfRed.jsp?iCve=64720107

Sánchez, K. (2007) Migración transfronteriza indígena en Darién. Eca Estudios Centroamericanos, 62. Recuperado el 4 de junio de 2013, de www. uca.edu.sv/publica/ued/eca-proceso/ecas

Silva, A., \&Guataquí, J. (2008). Caracterización instrumental del desplazamiento forzado en Colombia: hechos estilizados y la Encuesta Continua de Hogares (2001-2006). Revista de Ciencias Sociales, 14. Recuperado el 9 de may. De 2012, de http://www.scielo.org.ve/scielo.php?pid=S1315$5182008000300002 \&$ script=sci_arttext

Soto, E. (1998) El derecho fundamental de acceso a la justicia. Revista Chilena de derecho, número 1, Recuperado el 10 de enero de 2013, de dialnet.unirioja.es/descarga/articulo/264pdf

Treviño, R. (2007). Actualidad de la fenomenología en psicología. Diversitas, 3. $\begin{array}{lllllll}\text { Recuperado el } & 9 & \text { de } & \text { ag } & \text { De }\end{array}$ http://www.scielo.unal.edu.co/scielo.php?script=sci_arttext\&pid=S179499982007000200007\&lng=es\&nrm= 
Trindade, M. (2009) Cooperación internacional y desplazamiento interno en Colombia: Desafíos a la mayor crisis humanitaria de América del Sur. Revista. Internacional de direitos humanos, 6. Recuperado el 8 de ag. De 2012, de http://www.scielo.br/scielo.php?pid=S1806-

6444520090000100008\&script=sci_arttext

UARIV. Unidad para la Atención y la Reparación Integral a las Víctimas (2014) Enfoques diferenciales. Recuperado el 23 de abril de 2014, de: http://www.unidadvictimas.gov.co/index.php/en/438-enfoques-diferenciales

Velandia, A. (2004) Atención a la población en desplazamiento forzado interno en Colombia. Revista Cultura de los Cuidados, 2. Recuperado el 7 de jun. De 2012, de http://rua.ua.es/dspace/handle/10045/1023

Zamora Ramírez, M.E.R. (2007) El control subjetivo del proceso de trabajo. Tesis doctoral. Recuperado el 22 de abril de 2014, de http://148.206.53.84/tesiuami/UAMI14345.pdf 


\section{Anexo (1)}

Preguntas de la entrevista semiestructurada en cada una de las categorías preestablecidas

Derecho de acceso a la justicia

\begin{tabular}{|l|l|}
\hline \multicolumn{1}{|c|}{ Pregunta } & \multicolumn{1}{|c|}{$\begin{array}{c}\text { Categoría } \\
\text { preestablecida }\end{array}$} \\
\hline ¿Qué entiende por acceso a la justicia? & $\begin{array}{l}\text { Derecho de acceso a la } \\
\text { justicia }\end{array}$ \\
\hline $\begin{array}{l}\text { ¿Cómo se presentan ante los operadores jurídicos los } \\
\text { indígenas en situación de desplazamiento forzado? }\end{array}$ & $\begin{array}{l}\text { Derecho de acceso a la } \\
\text { justicia }\end{array}$ \\
\hline $\begin{array}{l}\text { ¿Cuáles son las dificultades que presentan los indígenas } \\
\text { en situación de desplazamiento forzado para acceder } \\
\text { a la justicia? }\end{array}$ & $\begin{array}{l}\text { Derecho de acceso a la } \\
\text { justicia }\end{array}$ \\
\hline $\begin{array}{l}\text { ¿Qué diferencias existen entre los desplazados de otros } \\
\text { grupos de personas (campesinos, negritudes) y los } \\
\text { indígenas en situación de desplazamiento forzado? }\end{array}$ & $\begin{array}{l}\text { Derecho de acceso a la } \\
\text { ¿Se diferencian las ayudas que reciben los grupos } \\
\text { indígenas y los no indígenas? ¿En qué? }\end{array}$ \\
\hline $\begin{array}{l}\text { ¿Cree que hay diferencias entre el trato que reciben los } \\
\text { grupos indígenas desplazados de parte de los operadores } \\
\text { de instituciones gubernamentales y no gubernamentales? } \\
\text { ¿Cuáles son esas diferencias? }\end{array}$ & $\begin{array}{l}\text { Derecho de acceso a la } \\
\text { justicia }\end{array}$ \\
\hline Desplazamo de acceso a la \\
\hline
\end{tabular}

Desplazamiento forzado

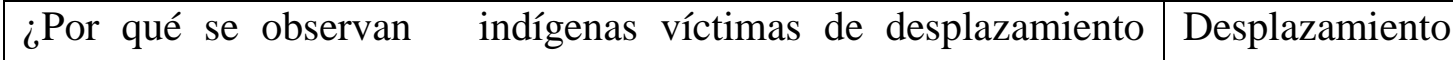
forzado deambulando en las calles de Bogotá?

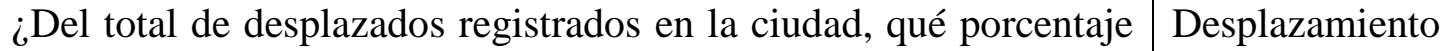
son indígenas?

¿Cómo se presenta el fenómeno del desplazamiento forzado de Desplazamiento indígenas en la capital? 


\begin{tabular}{|l|l|}
\hline $\begin{array}{l}\text { ¿Cuáles son las causas del desplazamiento forzado de } \\
\text { indígenas? }\end{array}$ & Desplazamiento \\
\hline ¿En qué casos el desplazamiento es forzado? & Desplazamiento \\
\hline $\begin{array}{l}\text { ¿De qué departamentos, ciudades y municipios proceden los } \\
\text { indígenas desplazados por la violencia? }\end{array}$ & Desplazamiento \\
\hline $\begin{array}{l}\text { ¿Cuáles son las etnias que presentan mayor número de desplazados } \\
\text { a causa de la violencia? ¿Provenientes de qué regiones o lugares? }\end{array}$ & Desplazamiento \\
\hline $\begin{array}{l}\text { ¿Cuáles son las etnias de indígenas desplazados que mejor se } \\
\text { adaptan a las condiciones de vida de la ciudad? }\end{array}$ & Desplazamiento \\
\hline $\begin{array}{l}\text { ¿En qué localidades de Bogotá son ubicados los indígenas } \\
\text { víctimas de desplazamiento forzado? }\end{array}$ & Desplazamiento \\
\hline $\begin{array}{l}\text { ¿A qué se debe que los indígenas en situación de } \\
\text { desplazamiento forzado, no se desplazan o buscan apoyo de otros } \\
\text { grupos indígenas? }\end{array}$ & Desplazamiento \\
\hline Víctima & \\
\hline
\end{tabular}

\section{Víctima}

\begin{tabular}{|l|l|}
\hline $\begin{array}{l}\text { ¿Qué piensa acerca de la vulneración de los Derechos Humanos de } \\
\text { los indígenas en situación de desplazamiento forzado? }\end{array}$ & Víctima \\
\hline $\begin{array}{l}\text { ¿Qué opina sobre la situación de los niños, discapacitados, mujeres } \\
\text { en embarazo, adolescentes y ancianos indígenas en situación de } \\
\text { desplazamiento forzado? y ¿Usted qué siente frente a este delito? }\end{array}$ & Víca \\
\hline $\begin{array}{l}\text { ¿Qué piensa acerca de los bienes que tienen que abandonar los } \\
\text { indígenas a causa del desplazamiento forzado? }\end{array}$ & Víctima \\
\hline $\begin{array}{l}\text { ¿Los indígenas en situación de desplazamiento forzado se consideran } \\
\text { víctimas o sólo desplazados? }\end{array}$ & Víctima \\
\hline $\begin{array}{l}\text { ¿Cómo se ven los indígenas así mismos, cuando viven el delito del } \\
\text { desplazamiento forzado? }\end{array}$ & Víctima \\
\hline $\begin{array}{l}\text { ¿Qué piensa sobre los cambios de costumbres alos que se ven } \\
\text { sometidos los indígenas en situación de desplazamiento forzado, } \\
\text { al trasladarse a vivir a la ciudad? (choque intercultural) }\end{array}$ & Víctima \\
\hline $\begin{array}{l}\text { ¿Qué sentimiento le causan los indígenas en situación de } \\
\text { desplazamiento forzado que padecen lesiones físicas? }\end{array}$ & Víctima \\
\hline
\end{tabular}


Implementación de las leyes

\begin{tabular}{|c|c|}
\hline 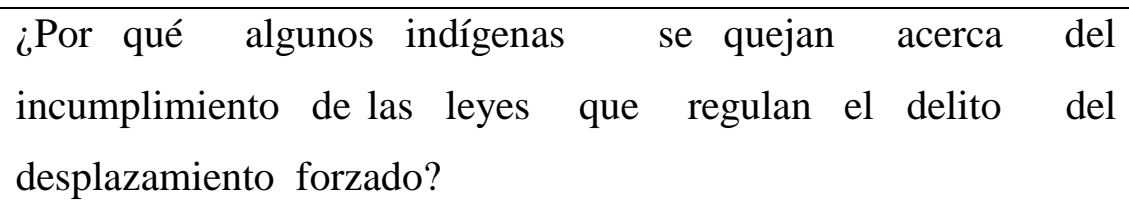 & $\begin{array}{l}\text { Implementación } \\
\text { de la ley }\end{array}$ \\
\hline $\begin{array}{l}\text { ¿Qué deben hacer las autoridades para prevenir el } \\
\text { desplazamiento forzado, según la ley } 387 \text { de } 1997 \text { y } 1448 \text { de } \\
2011 ?\end{array}$ & $\begin{array}{l}\text { Implementación } \\
\text { de la ley }\end{array}$ \\
\hline $\begin{array}{l}\text { ¿Qué medidas ordenadas en la sentencia T-025 de 2004, están } \\
\text { pendientes de cumplimiento? }\end{array}$ & $\begin{array}{l}\text { Implementación } \\
\text { de la ley }\end{array}$ \\
\hline $\begin{array}{l}\text { ¿Qué garantías ofrece la Ley } 1448 \text { de } 2011 \text { a los indígenas } \\
\text { víctimas de desplazamiento forzado? }\end{array}$ & $\begin{array}{l}\text { Implementación } \\
\text { de la ley }\end{array}$ \\
\hline $\begin{array}{l}\text { ¿Qué mecanismos se requieren para optimizar la atención, } \\
\text { asistencia y reparación estipulados en el Decreto Ley } 4633 \text { de } \\
2011 \text { ? }\end{array}$ & $\begin{array}{l}\text { Implementaci } \\
\text { de la ley }\end{array}$ \\
\hline $\begin{array}{l}\text { ¿De los derechos nombrados en la Ley } 975 \text { de } 2005 \text { que } \\
\text { favorecen a las comunidades indígenas víctimas de } \\
\text { desplazamiento forzado, cuáles se han ejecutado hasta el } \\
\text { momento y cuáles se encuentran pendientes por ejecutar? }\end{array}$ & $\begin{array}{l}\text { Implemen } \\
\text { de la ley }\end{array}$ \\
\hline $\begin{array}{l}\text { ¿Qué perjuicios sufren los indígenas en situación de } \\
\text { desplazamiento forzado, frente al incumplimiento de las leyes } \\
\text { que regulan la ocurrencia de este delito? }\end{array}$ & $\begin{array}{l}\text { Implementación } \\
\text { de la ley }\end{array}$ \\
\hline $\begin{array}{l}\text { ¿Qué sucede con los programas de protección para los } \\
\text { indígenas en situación de desplazamiento, establecidos en el } \\
\text { Decreto } 4800 \text { de } 2011 \text { ? }\end{array}$ & $\begin{array}{l}\text { Implementación } \\
\text { de la ley }\end{array}$ \\
\hline
\end{tabular}

\section{Atención, asistencia y reparación integral}

\begin{tabular}{|l|l|}
\hline $\begin{array}{l}\text { ¿Qué ha venido haciendo el Estado para atender a la población } \\
\text { indígena en situación de desplazamiento forzado? }\end{array}$ & $\begin{array}{l}\text { Atención, } \\
\text { asistencia y } \\
\text { reparación } \\
\text { integral }\end{array}$ \\
\hline $\begin{array}{l}\text { ¿Qué criterios se tienen en cuenta para la inclusión o exclusión } \\
\text { al Registro Único, de los indígenas en situación de de }\end{array}$ & $\begin{array}{l}\text { Atención, } \\
\text { asistencia y }\end{array}$ \\
\hline
\end{tabular}




\begin{tabular}{|c|c|c|}
\hline desplazamiento forzado? & $\begin{array}{l}\text { reparación } \\
\text { integral }\end{array}$ & \\
\hline $\begin{array}{l}\text { ¿Cuáles son las fortalezas y las debilidades de los procesos de } \\
\text { atención, asistencia y reparación implementados por la ley para } \\
\text { los indígenas en situación de desplazamiento forzado? }\end{array}$ & $\begin{array}{l}\text { Atención, } \\
\text { asistencia } \\
\text { reparación } \\
\text { integral }\end{array}$ & $\mathrm{y}$ \\
\hline $\begin{array}{l}\text { ¿Cuáles son las quejas más frecuentes por parte de los indígenas } \\
\text { en situación de desplazamiento forzado? }\end{array}$ & $\begin{array}{l}\text { Atención, } \\
\text { asistencia } \\
\text { reparación } \\
\text { integral }\end{array}$ & y \\
\hline $\begin{array}{l}\text { ¿Qué información reciben los indígenas en situación de } \\
\text { desplazamiento forzado de parte de los operadores jurídicos? }\end{array}$ & $\begin{array}{l}\text { Atención, } \\
\text { asistencia } \\
\text { reparación } \\
\text { integral }\end{array}$ & $\mathrm{y}$ \\
\hline $\begin{array}{l}\text { ¿Qué gestiones realizan los “Centros Dignificar” para } \\
\text { atender a los indígenas en situación de desplazamiento forzado } \\
\text { y cuáles se pueden mejorar? }\end{array}$ & $\begin{array}{l}\text { Atención, } \\
\text { asistencia } \\
\text { reparación } \\
\text { integral }\end{array}$ & $\mathrm{y}$ \\
\hline 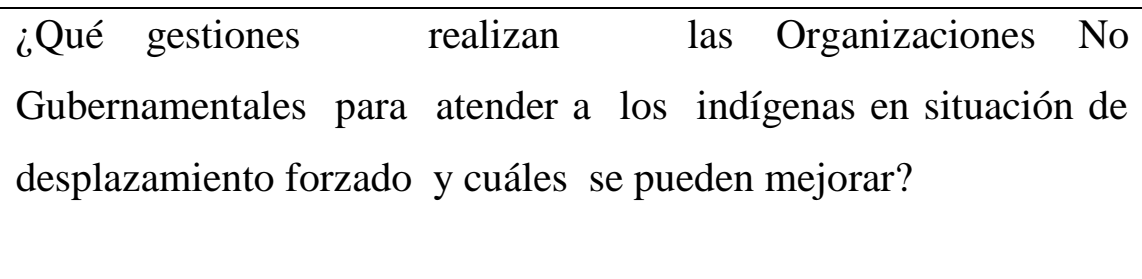 & $\begin{array}{l}\text { Atención, } \\
\text { asistencia } \\
\text { reparación } \\
\text { integral }\end{array}$ & $\mathrm{y}$ \\
\hline $\begin{array}{l}\text { ¿Qué trastornos o problemas psicológicos sufren los indígenas } \\
\text { víctimas de desplazamiento forzado? }\end{array}$ & $\begin{array}{l}\text { Atención, } \\
\text { asistencia } \\
\text { reparación } \\
\text { integral }\end{array}$ & y \\
\hline $\begin{array}{l}\text { ¿Cuál es el procedimiento para atender a los indígenas en } \\
\text { situación de desplazamiento forzado que padecen trastornos o } \\
\text { problemas psicológicos? }\end{array}$ & $\begin{array}{l}\text { Atención, } \\
\text { asistencia } \\
\text { reparación } \\
\text { integral }\end{array}$ & \\
\hline ¿Cuál es el procedimiento para atender a los inc & Ater & \\
\hline
\end{tabular}




\begin{tabular}{|c|c|c|}
\hline $\begin{array}{l}\text { situación de desplazamiento forzado que padecen enfermedades } \\
\text { de carácter físico? }\end{array}$ & $\begin{array}{l}\text { asistencia } \\
\text { reparación } \\
\text { integral }\end{array}$ & \\
\hline $\begin{array}{l}\text { ¿Por qué algunos indígenas en situación de desplazamiento } \\
\text { forzado afirman que no reciben atención, asistencia y reparación } \\
\text { integral? }\end{array}$ & $\begin{array}{l}\text { Atención, } \\
\text { asistencia } \\
\text { reparación } \\
\text { integral }\end{array}$ & $\mathrm{y}$ \\
\hline $\begin{array}{l}\text { ¿A qué se debe que algunos indígenas en situación de } \\
\text { desplazamiento forzado se encuentran ubicados en barrios } \\
\text { marginados de la capital, viviendo en condiciones de } \\
\text { hacinamiento? }\end{array}$ & $\begin{array}{l}\text { Atención, } \\
\text { asistencia } \\
\text { reparación } \\
\text { integral }\end{array}$ & $\mathrm{y}$ \\
\hline $\begin{array}{l}\text { ¿Cómo solucionan los conflictos que se presentan entre los } \\
\text { indígenas en situación de desplazamiento forzado? }\end{array}$ & $\begin{array}{l}\text { Atención, } \\
\text { asistencia } \\
\text { reparación } \\
\text { integral }\end{array}$ & $\mathrm{y}$ \\
\hline $\begin{array}{l}\text { ¿Qué estrategias emplean para respetar la cosmovisión y las } \\
\text { costumbres de los indígenas en situación de desplazamiento } \\
\text { forzado? }\end{array}$ & $\begin{array}{l}\text { Atención, } \\
\text { asistencia } \\
\text { reparación } \\
\text { integral }\end{array}$ & $\mathrm{y}$ \\
\hline $\begin{array}{l}\text { ¿Qué entidades han venido apoyando a los indígenas en } \\
\text { situación de desplazamiento forzado? }\end{array}$ & $\begin{array}{l}\text { Atención, } \\
\text { asistencia } \\
\text { reparación } \\
\text { integral }\end{array}$ & $\mathrm{y}$ \\
\hline $\begin{array}{l}\text { ¿Cómo se pueden mejorar las políticas y estrategias } \\
\text { empleadas para la atención de los indígenas en situación de } \\
\text { desplazamiento forzado? }\end{array}$ & $\begin{array}{l}\text { Atención, } \\
\text { asistencia } \\
\text { reparación } \\
\text { integral }\end{array}$ & \\
\hline
\end{tabular}

\section{Derecho a la justicia}

\begin{tabular}{|l|l|l|}
\hline ¿Cuántos procesos de imputación y fallos judiciales existen & Derecho a la \\
contra personas acusadas de ejecutar desplazamientos forzados a & justicia & \\
los grupos indígenas?
\end{tabular}




\begin{tabular}{|c|c|}
\hline $\begin{array}{l}\text { ¿Qué tipo de penas reciben los responsables de realizar } \\
\text { desplazamientos forzados de grupos indígenas? }\end{array}$ & $\begin{array}{l}\text { Derecho a la } \\
\text { justicia }\end{array}$ \\
\hline $\begin{array}{l}\text { ¿Qué piensa sobre la justicia y el modelo de justicia que se usa } \\
\text { para resolver estos crímenes (justicia transicional)? }\end{array}$ & $\begin{array}{l}\text { Derecho } \\
\text { justicia }\end{array}$ \\
\hline $\begin{array}{l}\text { ¿Qué significa justicia para los indígenas en situación de } \\
\text { desplazamiento forzado? }\end{array}$ & $\begin{array}{l}\text { Derecho } \\
\text { justicia }\end{array}$ \\
\hline ¿Qué concepto le merece la justicia occidental? & $\begin{array}{l}\text { Derecho } \\
\text { justicia }\end{array}$ \\
\hline $\begin{array}{l}\text { ¿Qué percepción tienen los indígenas en situación de } \\
\text { desplazamiento forzado acerca de la justicia occidental? }\end{array}$ & $\begin{array}{l}\text { Derecho a } \\
\text { justicia }\end{array}$ \\
\hline $\begin{array}{l}\text { ¿Qué deben hacer las instituciones gubernamentales para } \\
\text { garantizarles a los indígenas en situación de desplazamiento } \\
\text { forzado, el derecho de acceso a la justicia? }\end{array}$ & $\begin{array}{l}\text { Derecho } \\
\text { justicia }\end{array}$ \\
\hline $\begin{array}{l}\text { ¿Qué medidas adoptan las entidades gubernamentales para } \\
\text { garantizarles el derecho de acceso a la justicia, a los indígenas } \\
\text { en situación de desplazamiento forzado? }\end{array}$ & $\begin{array}{l}\text { Derecho a la } \\
\text { justicia }\end{array}$ \\
\hline
\end{tabular}




\section{Anexo (2)}

Listado de algunas asociaciones de grupos indígenas en Bogotá

\begin{tabular}{|c|c|c|c|}
\hline Nombre & Dirección & $\begin{array}{l}\text { Telé } \\
\text { fono }\end{array}$ & $\begin{array}{l}\text { Página } \\
\text { web }\end{array}$ \\
\hline $\begin{array}{l}\text { Fundación Sol Radiante Indígenas de } \\
\text { Colombia "Funsraicol" }\end{array}$ & $\begin{array}{l}\text { Transversal } 17 \\
\text { No. } \quad \text { 23A-08 } \\
\text { Barrio Santa Fe }\end{array}$ & $\begin{array}{l}2845296-. \\
3135827650\end{array}$ & $\begin{array}{l}\text { http://w } \\
\text { ww.funsr } \\
\text { aicol.es.t } \\
\text { 1/ }\end{array}$ \\
\hline $\begin{array}{l}\text { Organización Nacional Indígena de } \\
\text { Colombia "ONIC" }\end{array}$ & $\begin{array}{l}\text { Calle 12b No. 4- } \\
38\end{array}$ & $\begin{array}{l}2842168- \\
2811845- \\
2843465\end{array}$ & $\begin{array}{l}\text { http://cm } \\
\text { s.onic.or } \\
\text { g.co/?s= } \\
\text { ong\&x= } \\
1 \& y=9\end{array}$ \\
\hline $\begin{array}{l}\text { Autoridades indígenas de Colombia } \\
\text { "AICO" }\end{array}$ & $\begin{array}{l}\text { Calle } 23 \text { No. } 7-61 \\
\text { oficina } 302\end{array}$ & $\begin{array}{l}2868233- \\
3418930\end{array}$ & $\begin{array}{l}\text { http://w } \\
\text { ww.aicoc } \\
\text { olombia. } \\
\underline{\text { org/expl }} \\
\underline{\text { ore.html }}\end{array}$ \\
\hline Alianza social independiente "ASI" & $\begin{array}{l}\text { Calle } 17 \text { No. } 5-43 \\
\text { piso } 8\end{array}$ & 2827474 & $\begin{array}{l}\underline{\text { http://w }} \\
\underline{\text { ww.asico }} \\
\underline{\text { lombia.c }} \\
\underline{\text { om/Cont }} \\
\underline{\text { actenos.p }} \\
\underline{\text { hp }}\end{array}$ \\
\hline Asociación Minga & $\begin{array}{l}\text { Av calle } 19 \text { No. } \\
4-88 \text { oficina } 1203\end{array}$ & $\begin{array}{l}3804380- \\
3804400- \\
2849889\end{array}$ & $\begin{array}{l}\text { http://aso } \\
\text { ciacionm } \\
\text { inga.org/ }\end{array}$ \\
\hline La Alianza partido político & $\begin{array}{l}\text { Calle } 54 \text { No. } 10- \\
81 \text { oficina } 901\end{array}$ & 2484192 & $\begin{array}{l}\text { http://w } \\
\text { ww.laali } \\
\text { anza.org. }\end{array}$ \\
\hline
\end{tabular}




\begin{tabular}{|l|l|l|l|}
\hline $\begin{array}{l}\text { Asociación de autoridades } \\
\text { tradicionales indígenas "OPIC" }\end{array}$ & Carrera 28A No. & 2353848 & co/ \\
51-70 Galerías & 3113432270 & http://opi \\
ccolombi \\
3216412332 & a.org/ \\
\hline $\begin{array}{l}\text { Jóvenes indígenas de Colombia } \\
\text { "Funjinco" }\end{array}$ & Bogotá & 3118241627 & $\underline{\underline{\text { http://w }}}$ \\
$\underline{\underline{\text { ww.jove }}}$ \\
$\underline{\underline{\text { nesindig }}}$ \\
$\underline{\underline{\text { enas.com }}}$ \\
$\underline{\text { /desplaza }}$ \\
$\underline{\text { dos.html }}$ \\
\hline
\end{tabular}


Listado de algunas Organizaciones no Gubernamentales en Bogotá

\begin{tabular}{|c|c|c|c|}
\hline Nombre & Dirección & Teléfono & Página web \\
\hline $\begin{array}{l}\text { Instituto Latinoamericano para una } \\
\text { sociedad y un Derecho alternativos } \\
\text { "ILSA" }\end{array}$ & $\begin{array}{l}\text { Calle } 38 \text { No. } \\
16-48\end{array}$ & $\begin{array}{l}2884772- \\
2884854\end{array}$ & $\begin{array}{l}\text { http://ilsa.or } \\
\text { g.co:81/ }\end{array}$ \\
\hline $\begin{array}{l}\text { Colectivo de Abogados José Alvear } \\
\text { Restrepo "CAJAR" }\end{array}$ & $\begin{array}{l}\text { Edificio } \\
\text { Avianca: } \\
\text { calle } 16 \text { No. } \\
\text { 6-66 piso } 25\end{array}$ & $\begin{array}{l}7421313 \\
2824270\end{array}$ & $\begin{array}{l}\text { http://www. } \\
\text { colectivode } \\
\text { abogados.or } \\
\text { g/Alertas- } \\
\underline{\text { de- }} \\
\text { Accion, } 148\end{array}$ \\
\hline $\begin{array}{l}\text { Plataforma Colombiana de Derechos } \\
\text { Humanos, democracia y desarrollo }\end{array}$ & $\begin{array}{l}\text { Carrera } 25 \\
\text { No. } \quad 51-37 \\
\text { oficina } 301\end{array}$ & $\begin{array}{l}2555073- \\
3458329\end{array}$ & $\begin{array}{l}\text { http://desca } \\
\text { pitulobogot } \\
\text { a.wordpress } \\
\text {.com/ }\end{array}$ \\
\hline Hábitat para la humanidad Colombia & $\begin{array}{l}\text { Transversal } \\
27 \quad \text { A No } \\
53 \mathrm{~B}-31 \\
\text { Galerías }\end{array}$ & $\begin{array}{l}32350090 \\
2350090\end{array}$ & $\begin{array}{l}\text { http://www. } \\
\underline{\text { hphcolombi }} \\
\underline{\text { a.org/oficin }} \\
\underline{\text { a_nacional. }} \\
\underline{\text { htm }}\end{array}$ \\
\hline
\end{tabular}

Listado de “Centros Dignificar" en Bogotá

\begin{tabular}{|c|c|c|c|}
\hline Nombre & Dirección & Teléfono & Página web \\
\hline Centro Dignificar Ciudad Bolívar & $\begin{array}{l}\text { Carrera } 17 \mathrm{~F} \\
\text { No. } 69 \mathrm{~A}-32 \\
\text { sur Barrio } \\
\text { Lucero Bajo }\end{array}$ & $\begin{array}{l}3387000 \text { Ext } \\
5360 / 5361\end{array}$ & $\begin{array}{l}\text { http://www. } \\
\text { gobiernobo } \\
\text { gota.gov.co }\end{array}$ \\
\hline $\begin{array}{l}\text { Centro Dignificar Suba- Cade la } \\
\text { Gaitana }\end{array}$ & $\begin{array}{l}\text { Cade la } \\
\text { Gaitana Calle } \\
\text { 14b No. 91- }\end{array}$ & $\begin{array}{l}\text { Línea } 195 \\
3387000 \text { Ext. } \\
5378-5379\end{array}$ & $\begin{array}{l}\text { http://suba.g } \\
\text { ov.co/index. } \\
\text { php/compon }\end{array}$ \\
\hline
\end{tabular}




\begin{tabular}{|c|c|c|c|}
\hline & $\begin{array}{l}66 . \\
\text { SuperCade } \\
\text { Calle } 148 \text { No. } \\
103 \quad \text { b-95 } \\
\text { UAO Suba } \\
\text { Carrera } 91 \\
\text { No. } 147-01\end{array}$ & & 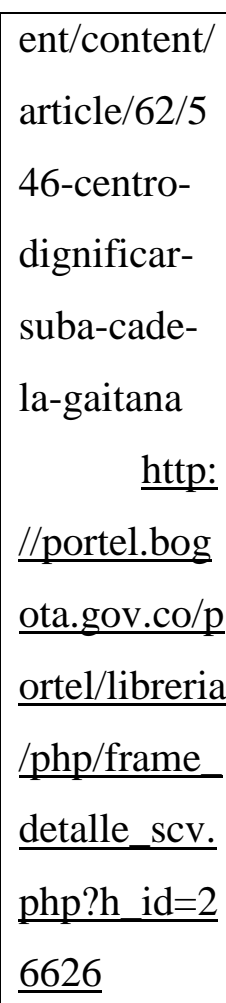 \\
\hline UAO Bosa- Kennedy & $\begin{array}{l}\text { Calle } 37 \text { sur } \\
\text { No. 72L-77 }\end{array}$ & $\begin{array}{l}3387000 \text { Ext. } \\
5380-5381\end{array}$ & $\begin{array}{l}\text { http://portel. } \\
\text { bogota.gov. } \\
\underline{\text { co/portel/lib }} \\
\text { reria/php/fra } \\
\text { me_detalle } \\
\underline{\text { scv.php?h_i }} \\
\text { d=26626 }\end{array}$ \\
\hline UAO Puente Aranda & $\begin{array}{l}\text { Carrera } 36 \\
\text { No. 18A- } 47\end{array}$ & $\begin{array}{l}2778311- \\
3387000 \text { Ext. } \\
5370-5371- \\
5372\end{array}$ & $\begin{array}{l}\text { http://portel. } \\
\text { bogota.gov. } \\
\underline{\text { co/portel/lib }} \\
\text { reria/php/fra } \\
\underline{\text { me_detalle }} \\
\underline{\text { scv.php?h_i }} \\
\underline{\mathrm{d}=26626}\end{array}$ \\
\hline UAO Rafael Uribe Uribe & $\begin{array}{l}\text { Cale 22sur } \\
\text { No. 14A- } 99\end{array}$ & $\begin{array}{l}3387000 \text { Ext. } \\
5373-5376- \\
5377\end{array}$ & $\begin{array}{l}\text { http://portel. } \\
\text { bogota.gov. } \\
\text { co/portel/lib }\end{array}$ \\
\hline
\end{tabular}




\begin{tabular}{|c|c|c|c|}
\hline & & & $\begin{array}{l}\text { reria/php/fra } \\
\text { me_detalle_ } \\
\underline{\text { scv.php?h_i }} \\
\underline{\mathrm{d}=26626}\end{array}$ \\
\hline UAO Terminal & $\begin{array}{l}\text { Calle } 22 \mathrm{c} \text { No. } \\
28 \mathrm{~F}- \\
\text { módulo } \\
\text { oficina } 108\end{array}$ & $\begin{array}{l}4282884 \quad- \\
3387000 \text { Ext. } \\
5374\end{array}$ & $\begin{array}{l}\text { http://portel. } \\
\text { bogota.gov. } \\
\underline{\text { co/portel/lib }} \\
\underline{\text { reria/php/fra }} \\
\underline{\text { me_detalle }} \\
\underline{\text { scv.php?h_i }} \\
\underline{\text { d=26626 }}\end{array}$ \\
\hline
\end{tabular}




\section{Anexo (3)}

\section{Consentimiento informado}

Otorgo mi consentimiento informado para participar en el estudio: "Representaciones sociales de algunos operadores jurídicos e indígenas en situación de desplazamiento forzado acerca del acceso a la justicia estatal". De igual modo, consiento la publicación de los resultados del mismo siempre que la información sea codificada protegiendo la identidad del entrevistado. Entiendo que, aunque se guardarán registros de mi participación en el estudio; los datos recogidos de mi intervención serán identificados a través de un código.

1. He sido informado de que mi participación en la presente investigación implica exponer mis opiniones frente al acceso a la justicia estatal de indígenas en situación de desplazamiento forzado

2. He sido informado de la inexistencia de procedimientos "engañosos" en este estudio. Todos los procedimientos son lo que parecen.

3. He sido informado de que soy libre de conceder o no conceder las entrevistas para efectuar la mencionada investigación.

(Entrevistador)

(Participante)

\section{(Fecha)}

